Portland State University

PDXScholar

3-10-1994

\title{
Synthesis and Characterization of some Flourine- containing Lithium Alkyl Sulfonates: Flourinated Sulfonates and SF5-containing Sulfonates
}

Steven A. Ullrich

Portland State University

Follow this and additional works at: https://pdxscholar.library.pdx.edu/open_access_etds

Part of the Chemistry Commons

Let us know how access to this document benefits you.

Recommended Citation

Ullrich, Steven A., "Synthesis and Characterization of some Flourine-containing Lithium Alkyl Sulfonates: Flourinated Sulfonates and SF5-containing Sulfonates" (1994). Dissertations and Theses. Paper 4880. https://doi.org/10.15760/etd.6756

This Thesis is brought to you for free and open access. It has been accepted for inclusion in Dissertations and Theses by an authorized administrator of PDXScholar. Please contact us if we can make this document more accessible: pdxscholar@pdx.edu. 
The Abstract and thesis of Steven A. Ullrich for the Master of Science degree in Chemistry was presented March 10, 1994 and accepted by the thesis committee and the department.

COMMITTEE APPROVALS :
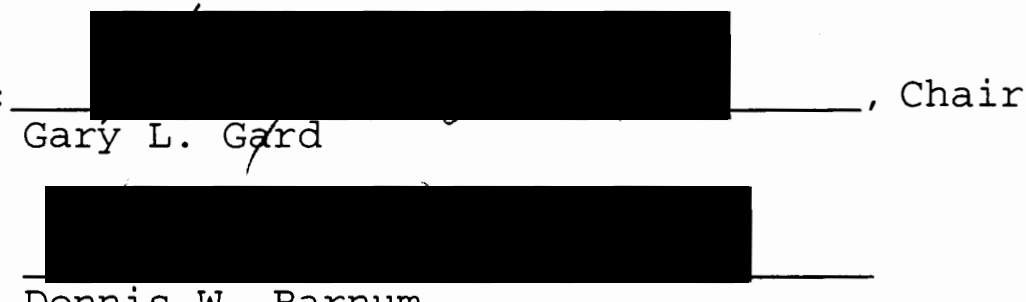

Dennis W. Barnum
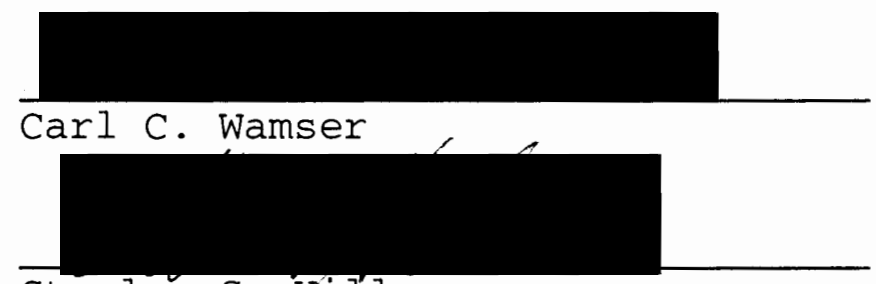

Stanley S. Hillman

Representative of the office of Graduate Studies

DEPARTMENT APPROVAL:

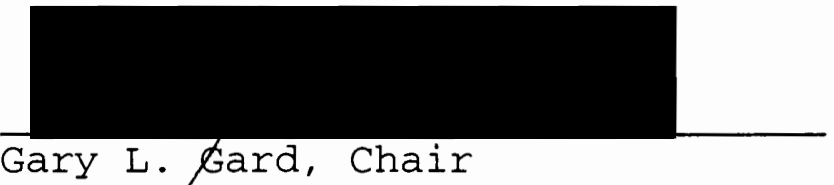

Department of Chemistry

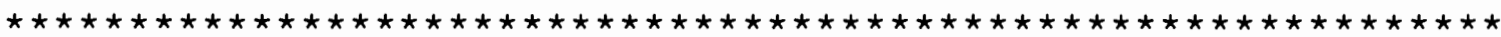

ACCEPTED FOR PORTLAND STATE UNIVERSITY BY THE LIBRARY

by

on

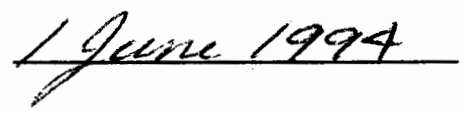




\section{ABSTRACT}

An abstract of the thesis of Steven A. Ullrich for the Master of Science in Chemistry presented March 10, 1994.

Title: Synthesis and Characterization of Some FluorineContaining Lithium Alkyl sulfonates: Fluorinated Sulfonates and $\mathrm{SF}_{5}$-Containing Sulfonates

Lithium salts of pentafluorothio alkyl sulfonic acids and perfluoroalkyl disulfonic acids were prepared for testing for possible use as polymer electrolytes.

Most of these lithium salts were made from the corresponding sodium, potassium or calcium salts. Aqueous solutions of these salts were passed through polystyrene sulfonate ion exchange resin in the acid form to obtain aqueous solutions of the corresponding acids. The acids were then neutralized with lithium hydroxide using a pH meter. One salt was made by reacting the barium salt of the corresponding acid with lithium sulfate.

A sulfonyl fluoride polymer

$\left(-\mathrm{O}-\mathrm{CH}_{2}-\mathrm{C}\left(\mathrm{CH}_{2} \mathrm{OCF}_{2} \mathrm{CF}_{2} \mathrm{SO}_{2} \mathrm{~F}\right) \mathrm{H}-\right)_{\mathrm{n}}$ was reacted with lithium hydroxide to give a lithium salt as well.

Owing to the great length of time required to dry these hydroscopic salts so that they might be suitable for polymer 
electrolyte work, alternative, water-free methods of preparation were explored. These include the reaction of lithium trimethylsilanolate with a sulfonyl fluoride, and the reaction of trimethylsilyl triflate with lithium chloride.

Conductivity studies were performed on samples of these salts, and the results so far obtained from these studies are presented.

Mass spectrometry, ${ }^{1} \mathrm{H}, \quad{ }^{19} \mathrm{~F}$ and ${ }^{13} \mathrm{C}$ nuclear magnetic resonance spectroscopy, infrared spectroscopy, and elemental analysis were used to help characterize the new lithium salts. 


\begin{abstract}
SYNTHESIS AND CHARACTERIZATION OF SOME
FLUORINE-CONTAINING LITHIUM ALKYL SULFONATES:

FLUORINATED SULFONATES AND $\mathrm{SF}_{5}$-CONTAINING SULFONATES
\end{abstract}

by

STEVEN A. ULLRICH

A thesis submitted in partial fulfillment of the requirements for the degree of

MASTER OF SCIENCE

in

CHEMISTRY

Portland State University

1994 


\section{ACKNOWLEDGEMENTS}

Dr. Gary L. Gard deserves more thanks than words can adequately express; his fertile imagination, guidance in perplexity, willingness to aid and moral support have helped in directing this thesis work toward completion.

His research group comes in as well for its share of thanks; Nicolas N. Hamel, Dale Braden, N. Robert Holcomb, Dr. Rolf $W$. Winter and Michael Hare have taught lab technique, have run spectra, have aided in spectral interpretation, and have given help in a thousand little ways.

Chang-Hwa Ryu gave invaluable aid in mass spectroscopy .

Dr. David H. Peyton shed much light on the NMR spectra; his aid was above and beyond the call of duty.

Dr. Michael Lerner and his research group at oregon state University should be duly acknowledged here for their conductivity studies on the lithium salts. Dr. Fred E. Behr of $3 \mathrm{M}$ Company is to be thanked for his generous gift of many fluorinated chemical samples. Dr. Michael Armand, of the Laboratoire D'Ionique et D'Electrochimie des Solides-Grenoble, provided Dr. Gard with valuable information concerning the work, especially on the lithium trimethylsilanolate-sulfonyl fluoride reaction. 
ACKNOWLEDGEMENTS . . . . . . . . . . . . . . . . . . . . . ii LIST OF TABLES . . . . . . . . . . . . . . . . . . . . . v LIST OF FIGURES . . . . . . . . . . . . . . . . . . . . . . vii CHAPTER

I INTRODUCTION .................... 1

Solid Electrolytes . . . . . . . . . . . 1

Polymer Electrolytes . . . . . . . . . 3

Lithium Batteries and

Lithium Polymer Electrolytes . . . . . . 9

II SYNTHESIS . . . . . . . . . . . . . . . . . 14

General Considerations . . . . . . . . . 14

New Fluorinated Lithium Salts . . . . . . . . 15

III EXPERIMENTAL . . . . . . . . . . . . . . . . . . 19

Vacuum Line... . . . . . . . . . . 19

Reaction Vessels . . . . . . . . . . . 19

Instrumentation and Characterization . . . . . 20

Dry Box . . . . . . . . . . . . . . . 21

Reagents . . . . . . . . . . . . . . 21

IV PREPARATION OF LITHIUM SULFONATES . . . . . . . . . . 24

Discussion ................ . . 24

Ion Exchange Resin Capacity Test . . . . . . 28

Synthesis of $\mathrm{SF}_{5} \mathrm{CH}_{2} \mathrm{CH}_{2} \mathrm{SO}_{3} \mathrm{Li}$. . . . . . . . . 30

Synthesis of $\mathrm{SF}_{5} \mathrm{CH}_{2} \mathrm{CF}_{2} \mathrm{SO}_{3} \mathrm{Li}$. . . . . . . . . . 31

Synthesis of $\mathrm{SF}_{5} \mathrm{CHFCF}_{2} \mathrm{SO}_{3} \mathrm{Li}$. . . . . . . . . 31

Synthesis of $\mathrm{CF}_{2}\left(\mathrm{SO}_{2} \mathrm{OLi}\right)_{2}$. . . . . . . . . . . 32

Synthesis of $\left(\mathrm{CF}_{2} \mathrm{SO}_{2} \mathrm{OLi}\right)_{2}$. . . . . . . . . . 32

Synthesis of $\mathrm{CF}_{2}\left(\mathrm{CF}_{2} \mathrm{SO}_{2} \mathrm{OLi}\right)_{2}$. . . . . . . . . . 33 
Synthesis of $\left(\mathrm{CF}_{2} \mathrm{CF}_{2} \mathrm{SO}_{2} \mathrm{OLi}\right)_{2}$. . . . . . . . . . 33

Synthesis of $\mathrm{O}\left(\mathrm{CF}_{2} \mathrm{CF}_{2} \mathrm{SO}_{2} \mathrm{OLi}\right)_{2}$. . . . . . . . . 34

Polymer salt Synthesis . . . . . . . . . 34

Elemental Analyses . . . . . . . . . . 37

Mass Spectra . . . . . . . . . . . . . 38

Infrared Spectra . . . . . . . . . . . . 60

NMR Spectra................. 70

V OTHER PATHWAYS . . . . . . . . . . . . . . . . 85

VI RESULTS AND DISCUSSION ................. . . 92

Preparation . . . . . . . . . . . . 92

Properties of the Lithium Compounds . . . . . . 96

Stability . . . . . . . . . . 96

Solubility . . . . . . . . . . . 97

Conductivity . . . . . . . . . . . 98

Conclusions . . . . . . . . . . . . . . 99

REFERENCES ............................ . . 101

APPENDIX FIGURES . . . . . . . . . . . . . . . . . . . . . . 111 
I

XV

XVI

XVII

XVIII

XIX

$\mathrm{XX}$

XXI

XXII

XXIII

XXIV

XXV

XVI

Lithium Salt Complexes with Poly (ethylene oxide) • . . 12 Elemental Analysis . . . . . . . . . . . . . 37 Mass Spectrum of $\mathrm{SF}_{5} \mathrm{CH}_{2} \mathrm{CH}_{2} \mathrm{SO}_{2} \mathrm{OLi}$ - Positive Mode . . . . 42 Mass Spectrum of $\mathrm{SF}_{5} \mathrm{CH}_{2} \mathrm{CH}_{2} \mathrm{SO}_{2} \mathrm{OLi}$ - Negative Mode . . . . 43 Mass Spectrum of $\mathrm{SF}_{5} \mathrm{CH}_{2} \mathrm{CF}_{2} \mathrm{SO}_{2} \mathrm{OLi}$ - Positive Mode . . . . 44 Mass Spectrum of $\mathrm{SF}_{5} \mathrm{CH}_{2} \mathrm{CF}_{2} \mathrm{SO}_{2} \mathrm{OLi}$ - Negative Mode . . . . 45 Mass Spectrum of $\mathrm{SF}_{5} \mathrm{CHFCF}_{2} \mathrm{SO}_{2} \mathrm{OLI}$ - Positive Mode . . . 46 Mass Spectrum of $\mathrm{SF}_{5} \mathrm{CHFCF}_{2} \mathrm{SO}_{2} \mathrm{OLi}$ - Negative Mode . . . 47 Mass Spectrum of $\mathrm{CF}_{2}\left(\mathrm{SO}_{2} \mathrm{OLi}\right)_{2}$ - Positive Mode . . . . 48 Mass Spectrum of $\mathrm{CF}_{2}\left(\mathrm{SO}_{2} \mathrm{OLI}\right)_{2}$ - Negative Mode . . . . . 49 Mass Spectrum of $\left(\mathrm{CF}_{2} \mathrm{SO}_{2} \mathrm{OLi}\right)_{2}$ - Positive Mode . . . . . 51 Mass Spectrum of $\left(\mathrm{CF}_{2} \mathrm{SO}_{2} \mathrm{OLi}\right)_{2}$ - Negative Mode . . . . . 52 Mass Spectrum of $\mathrm{CF}_{2}\left(\mathrm{CF}_{2} \mathrm{SO}_{2} \mathrm{OLi}\right)_{2}$ - Positive Mode . . . 54 Mass Spectrum of $\mathrm{CF}_{2}\left(\mathrm{CF}_{2} \mathrm{SO}_{2} \mathrm{OLi}\right)_{2}$ - Negative Mode . . . . 55 Mass Spectrum of $\left(\mathrm{CF}_{2} \mathrm{CF}_{2} \mathrm{SO}_{2} \mathrm{OLi}\right)_{2}$ - Positive Mode . . . 56 Mass Spectrum of $\left(\mathrm{CF}_{2} \mathrm{CF}_{2} \mathrm{SO}_{2} \mathrm{OLi}\right)_{2}$ - Negative Mode . . . . 57 Mass Spectrum of $\mathrm{O}\left(\mathrm{CF}_{2} \mathrm{CF}_{2} \mathrm{SO}_{2} \mathrm{OLi}\right)_{2}$ - Positive Mode - . 58 Mass Spectrum of $\mathrm{O}\left(\mathrm{CF}_{2} \mathrm{CF}_{2} \mathrm{SO}_{2} \mathrm{OLi}\right)_{2}$ - Negative Mode . . 59 IR Data for $\mathrm{SF}_{5} \mathrm{CH}_{2} \mathrm{CH}_{2} \mathrm{SO}_{2} \mathrm{OLi}$. . . . . . . . . . . . . 63 IR Data for $\mathrm{SF}_{5} \mathrm{CH}_{2} \mathrm{CF}_{2} \mathrm{SO}_{2} \mathrm{OLi}$. . . . . . . . . . . . . . 64 IR Data for $\mathrm{SF}_{5} \mathrm{CHFCF}_{2} \mathrm{SO}_{2} \mathrm{OLI}$. . . . . . . . . . . . 65 IR Data for $\mathrm{CF}_{2}\left(\mathrm{SO}_{2} \mathrm{OLi}\right)_{2}$. . . . . . . . . . . . . 66 IR Data for $\left(\mathrm{CF}_{2} \mathrm{SO}_{2} \mathrm{OLi}\right)_{2}$. . . . . . . . . . . . . . 67 IR Data for $\mathrm{CF}_{2}\left(\mathrm{CF}_{2} \mathrm{SO}_{2} \mathrm{OLI}\right)_{2}$. . . . . . . . . . . . . 67 IR Data for $\left(\mathrm{CF}_{2} \mathrm{CF}_{2} \mathrm{SO}_{2} \mathrm{OLi}\right)_{2}$. . . . . . . . . . . . . 68 IR Data for $\mathrm{O}\left(\mathrm{CF}_{2} \mathrm{CF}_{2} \mathrm{SO}_{2} \mathrm{OLi}\right)_{2}$. . . . . . . . . . . . . 69 
XXVII IR Data for Polymer of $\mathrm{OCH}_{2}-\mathrm{CH}-\mathrm{CH}_{2}-\mathrm{OCF}_{2} \mathrm{CF}_{2} \mathrm{SO}_{2} \mathrm{OLi}$. . . 69 XXVIIINMR Data for $\mathrm{SF}_{5} \mathrm{CH}_{2} \mathrm{CH}_{2} \mathrm{SO}_{2} \mathrm{OLi}$. . . . . . . . . . . 81 XXIX NMR Data for $\mathrm{SF}_{5} \mathrm{CH}_{2} \mathrm{CF}_{2} \mathrm{SO}_{2} \mathrm{OLi}$. . . . . . . . . . 82 $\mathrm{XXX} \quad \mathrm{NMR}$ Data for $\mathrm{SF}_{5} \mathrm{CHFCF}_{2} \mathrm{SO}_{2} \mathrm{OLI}$. . . . . . . . . 83 XXXI ${ }^{19} \mathrm{~F}$ NMR Data for Perfluoroalkyl Disulfonic Acid Dilithium Salts . . . . . . . . . . 83

XXXII ${ }^{13} \mathrm{C}$ NMR Data for Perfluoroalkyl Disulfonic Acid Dilithium Salts . . . . . . . . . . . 84

XXXIII Decomposition Point of Lithium Sulfonates . . . . . 95 XXXIV Estimate of Solubility of Perfluoroalkyl Disulfonic Acid Dilithium Salts . . . . . . . . 96 XXXV Conductivity of Lithium Sulfonates . . . . . . . . 96 
1 Plot of Log (Conductivity. $\Omega \cdot \mathrm{cm}$ ) vs. $1000 / \mathrm{T}$

(in $K$ ) for Perfluoroalkane Disulfonic Acid

Dilithium Salts.................. . 112

2 Infrared spectrum of $\mathrm{SF}_{5} \mathrm{CH}_{2} \mathrm{CH}_{2} \mathrm{SO}_{3} \mathrm{Li}$. . . . . . . . . . . . 113

3 Infrared Spectrum of $\mathrm{SF}_{5} \mathrm{CH}_{2} \mathrm{CF}_{2} \mathrm{SO}_{3} \mathrm{Li}$. . . . . . . . . . . . . 114

4 Infrared Spectrum of $\mathrm{SF}_{5} \mathrm{CHFCF}_{2} \mathrm{SO}_{3} \mathrm{Li}$. . . . . . . . . . . . . 115

5 Infrared Spectrum of $\mathrm{CF}_{2}\left(\mathrm{SO}_{3} \mathrm{Li}\right)_{2}$. . . . . . . . . . . . 116

6 Infrared Spectrum of $\left(\mathrm{CF}_{2} \mathrm{SO}_{3} \mathrm{Li}\right)_{2}$. . . . . . . . . . . . . . . 117

7 Infrared Spectrum of $\mathrm{CF}_{2}\left(\mathrm{CF}_{2} \mathrm{SO}_{3} \mathrm{Li}\right)_{2}$. . . . . . . . . . . . . 118

8 Infrared Spectrum of $\left(\mathrm{CF}_{2} \mathrm{CF}_{2} \mathrm{SO}_{3} \mathrm{Li}\right)_{2}$. . . . . . . . . . . . . 119

9 Infrared Spectrum of $\mathrm{O}_{\left(\mathrm{CF}_{2} \mathrm{CF}_{2} \mathrm{SO}_{3} \mathrm{Li}\right)_{2}}$. . . . . . . . . . . . . 120

10 Infrared Spectrum of $\left(\mathrm{OCH}_{2} \mathrm{C}\left(\mathrm{CH}_{2} \mathrm{OCF}_{2} \mathrm{CF}_{2} \mathrm{SO}_{3} \mathrm{Li}\right) \mathrm{H}\right)_{n}$. . . . . . . 121

$11{ }^{1} \mathrm{H}$ NMR Spectrum of $\mathrm{SF}_{5} \mathrm{CH}_{2} \mathrm{CH}_{2} \mathrm{SO}_{3} \mathrm{Li}$. . . . . . . . . . . . . 122

$12{ }^{19} \mathrm{~F}$ NMR Spectrum of $\mathrm{SF}_{5} \mathrm{CH}_{2} \mathrm{CH}_{2} \mathrm{SO}_{3} \mathrm{Li}-\mathrm{SF}_{5}$ Axial Fluorine . . . . 123

$13{ }^{19} \mathrm{~F}$ NMR Spectrum of $\mathrm{SF}_{5} \mathrm{CH}_{2} \mathrm{CH}_{2} \mathrm{SO}_{3} \mathrm{Li}-\mathrm{SF}_{5}$ Equatorial Fluorines . 124

$14{ }^{19} \mathrm{~F}$ NMR Spectrum of $\mathrm{SF}_{5} \mathrm{CH}_{2} \mathrm{CH}_{2} \mathrm{SO}_{3} \mathrm{Li}$ - $\boldsymbol{\beta}$ Carbon; Proton Coupled . 125

$15{ }^{1} \mathrm{H}$ NMR Spectrum of $\mathrm{SF}_{5} \mathrm{CH}_{2} \mathrm{CF}_{2} \mathrm{SO}_{3} \mathrm{Li}$. . . . . . . . . . . . 126

$16{ }^{19} \mathrm{~F}$ NMR Spectrum of $\mathrm{SF}_{5} \mathrm{CH}_{2} \mathrm{CF}_{2} \mathrm{SO}_{3} \mathrm{Li}$. . . . . . . . . . . . . . 127

$17{ }^{13} \mathrm{C}$ NMR Spectrum of $\mathrm{SF}_{5} \mathrm{CH}_{2} \mathrm{CF}_{2} \mathrm{SO}_{3} \mathrm{Li}$. . . . . . . . . . . . 128

$18{ }^{1} \mathrm{H}$ NMR Spectrum of $\mathrm{SF}_{5} \mathrm{CHFCF}_{2} \mathrm{SO}_{3} \mathrm{Li}$. . . . . . . . . . . . . 129

$19{ }^{19} \mathrm{~F}$ NMR Spectrum of $\mathrm{SF}_{5} \mathrm{CHFCF}_{2} \mathrm{SO}_{3} \mathrm{Li}$. . . . . . . . . . . 130

$20{ }^{13} \mathrm{C}$ NMR spectrum of $\mathrm{SF}_{5} \mathrm{CHFCF}_{2} \mathrm{SO}_{3} \mathrm{Li}$

- $\beta$ Carbon, Proton Decoupled .............. 131

$21{ }^{19} \mathrm{~F}$ and ${ }^{13} \mathrm{C}$ NMR Spectra of $\mathrm{CF}_{2}\left(\mathrm{SO}_{3} \mathrm{Li}\right)_{2}$. . . . . . . . . . 132

$22{ }^{13} \mathrm{C}$ NMR Spectrum of $\left(\mathrm{CF}_{2} \mathrm{SO}_{3} \mathrm{Li}\right)_{2}$. . . . . . . . . . . . . 133

$23{ }^{19} \mathrm{~F}$ NMR Spectra of $\mathrm{CF}_{2}\left(\mathrm{CF}_{2} \mathrm{SO}_{3} \mathrm{Li}\right)_{2}$. . . . . . . . . . . . 134

$24{ }^{13} \mathrm{C}$ NMR Spectrum of $\mathrm{CF}_{2}\left(\mathrm{CF}_{2} \mathrm{SO}_{3} \mathrm{Li}\right)_{2}$. . . . . . . . . . . 135

$25{ }^{19} \mathrm{~F}$ NMR Spectra of $\left(\mathrm{CF}_{2} \mathrm{CF}_{2} \mathrm{SO}_{3} \mathrm{Li}\right)_{2}$. . . . . . . . . . . 136 
$26{ }^{13} \mathrm{C}$ NMR Spectra of $\left(\mathrm{CF}_{2} \mathrm{CF}_{2} \mathrm{SO}_{3} \mathrm{Li}\right)_{2}$. . . . . . . . . . . . 137

$27{ }^{19} \mathrm{~F}$ NMR Spectra of $\mathrm{O}\left(\mathrm{CF}_{2} \mathrm{CF}_{2} \mathrm{SO}_{3} \mathrm{Li}\right)_{2}$. . . . . . . . . . . . . 138

$28{ }^{13} \mathrm{C}$ NMR Spectra of $\mathrm{O}_{\left(\mathrm{CF}_{2} \mathrm{CF}_{2} \mathrm{SO}_{3} \mathrm{Li}\right)_{2}}$. . . . . . . . . . . . . . 139

$29{ }^{1} \mathrm{H}$ NMR spectrum of $\left(\mathrm{OCH}_{2} \mathrm{C}\left(\mathrm{CH}_{2} \mathrm{OCF}_{2} \mathrm{CF}_{2} \mathrm{SO}_{3} \mathrm{Li}\right)_{\mathrm{H}}\right)_{\mathrm{n}}$. . . . . . . . 140

$30{ }^{19} \mathrm{~F}$ NMR Spectrum of $\left(\mathrm{OCH}_{2} \mathrm{C}\left(\mathrm{CH}_{2} \mathrm{OCF}_{2} \mathrm{CF}_{2} \mathrm{SO}_{3} \mathrm{Li}\right) \mathrm{H}\right)_{\mathrm{n}}$. . . . . . . 141 
CHAPTER I

INTRODUCTION

SOLID ELECTROLYTES

A solid having electrical conductivity solely due to ionic transport and not to moving electrons is called a solid electrolyte or fast ion conductor. ${ }^{1}$ Solid electrolytes ${ }^{2-6}$ show great diversity. ${ }^{7}$ There are crystalline ceramic sodium $\beta$-aluminas ${ }^{8,9}$ and stabilized zirconias ${ }^{2,6}$ as well as the soft crystalline rubidium silver iodide ${ }^{10-13}$ and fragile amorphous polymer electrolytes like lithium triflate in poly(ethylene oxide). Some solid electrolytes conduct cations (silver iodide), while others conduct anions (lead fluoride).

Trying to determine the mechanism by which each electrolyte conducts electrical current has been a driving force in the investigation of solid electrolytes.5,14 $\mathrm{X}$-ray crystal structures, phase diagrams, nuclear magnetic resonance studies and a host of other methods of investigation have been employed to determine how each electrolyte works.

C.A. Tubandt in 1910 sent a measured quantity of electricity through a silver iodide pellet heated to $150^{\circ} \mathrm{C}$, and found that the weight of silver deposited at the cathode 
was proportional to the quantity of current used. In this way Tubandt discovered that silver iodide is a fast ion conductor; it is the silver ion that carries the current. ${ }^{2}$ His aim in this work was to explain why the conductivity of silver iodide jumps about two orders of magnitude ${ }^{15}$ within a small temperature range. This is a phenomenon that has been noticed in other solid electrolytes as well: there is a low-temperature ordered form of the solid in question that does not conduct nearly as well as a disordered hightemperature form. ${ }^{2}$

Tubandt's results did not receive the attention they deserved. The 1960's brought the discoveries of sodium $\beta$ alumina $(1965)^{16}$ and rubidium silver iodide (1967).10-13

These two solids have such high conductivity--the rubidium silver iodide having a conductivity on the same order as $35 \%$ sulfuric acid ${ }^{17}$--that researchers became excited by the prospect of finding new fast ion conductors. ${ }^{6}$

Technological uses followed closely on the heels of newly discovered solid electrolytes; indeed, the discovery of sodium $\beta$-alumina and the idea for a new high energy density sodium-sulfur battery ${ }^{18}$ employing this solid electrolyte was announced on the same day. ${ }^{2}$ Batteries continue to be a major application for fast ion conductors; ${ }^{1,19-23}$ pacemaker batteries have been constructed using more than one solid electrolyte system.1.3 ${ }^{13}$ stabilized zirconias are employed in monitoring the oxygen content of 
automobile exhaust. ${ }^{3,24}$ Coulometers, time switches, analog memories and capacitors are among the electrical applications of fast ion electrolytes. ${ }^{24}$ "Smart windows," windows that adapt to an increase in summer sun by absorbing more light, require a polymer electrolyte layer. ${ }^{25-27}$ The future can only bring still more uses for these versatile substances.

\section{POLYMER ELECTROLYTES}

Polymer electrolytes ${ }^{26,28,29}$ are complexes of metal salts with certain kinds of polymers. They are usually made by dissolving the salt and polymer in an appropriate ratio in a solvent, and then evaporating away the solvent. ${ }^{2}$

P.V. Wright and colleagues prepared the first such complex from poly(ethylene oxide) and potassium thiocyanate, ${ }^{30}$ and later established that this complex did indeed conduct electricity. ${ }^{2,31} \mathrm{M}$. Armand and his team did systematic work in preparing new polymer electrolytes; they were the first to suggest that this new class of fast ion conductors could be employed in batteries. ${ }^{2,28}$ Interest was piqued, and in subsequent years a number of international symposia have been held on the subject of polymer electrolytes. J.R. MCCallum and C.A. Vincent have produced two volumes of Polymer Electrolyte Reviews (Elsevier Applied Science; 1987, 1989) covering many aspects of this fast growing field. 
Since so many of the classic studies of polymer electrolytes have been made using poly (ethylene oxide), PEO, as the polymer, it is fitting to give further details about these complexes. ${ }^{26}$ The electrolyte complex is formed between the oxygen atoms of PEO and the cations of the metal salt. ${ }^{2}$ Poly (ethylene oxide) has an oxygen spacing ideal for creation of a large number of coordination sites for cations. ${ }^{32}$ PEO

$$
\left(-\mathrm{CH}_{2}-\mathrm{CH}_{2}-\mathrm{O}-\right)_{n}
$$

forms complexes, while poly (methylene oxide)

$$
\left(-\mathrm{CH}_{2}-\mathrm{O}-\right)_{\mathrm{n}}
$$

and poly (trimethylene oxide)

$$
\left(-\mathrm{CH}_{2}-\mathrm{CH}_{2}-\mathrm{CH}_{2}-\mathrm{O}-\right)_{\mathrm{n}}
$$

do not. ${ }^{28.32}$

The first $x$-ray crystallographic studies of PEO appeared to indicate that it is perfectly helically shaped, with seven $\left(-\mathrm{CH}_{2}-\mathrm{CH}_{2}-\mathrm{O}-\right)$ units in two turns of the helix. ${ }^{33}$ While subsequent work shows it to be less ordered than this, ${ }^{28}$ the structure is still generally helical. The tunnel-like hole about which the molecule coils is lined with oxygen atoms. The radius of this hole is $1.3-1.5 \AA$, large enough to accommodate sodium $(0.99 \AA)$ or lithium $\left(0.58 \AA\right.$ ) ions. $^{34}$ One study considers every alkali metal ion in the complex to have four neighboring oxygens, arranged roughly tetrahedrally, ${ }^{35}$ but this may be an oversimplification. ${ }^{28}$ Vibrational spectroscopy does reveal 
Raman-active bands which may be assigned to a metal-oxygen breathing mode, and far infrared bands similar to known examples of solvent-cage vibrations. ${ }^{35}$ In the breathing mode, the poly (ethylene oxide) skeleton is coiling and uncoiling. Therefore, the distance between the metal and the oxygen attached to the skeleton is changing. So, although it is the PEO framework that is "breathing," the name becomes transferred to the resultant metal-oxygen vibration.

The exact mechanism by which metal ions move through the PEO tunnel is at present unknown; ${ }^{28,36}$ partly, it appears, the ions are moved along by the motion of the polymer segments carrying them. ${ }^{36}$

Although there are still investigators working with pure $\mathrm{PEO}, 32,37,38$ it no longer has a virtual monopoly on the polymer electrolyte market. The change comes from the discovery that polymer electrolytes exhibit their high conductivity only in the high temperature amorphous state. ${ }^{32}$ Earlier work attributed conductivity to the crystalline state of the complex, but such conductivity as was measured was due to pockets of amorphous material in a crystalline matrix. ${ }^{39}$ Because PEO makes its transition from lowtemperature crystalline to high-temperature amorphous phase at $60^{\circ} \mathrm{C}$, batteries made using PEO must operate above this temperature--at, say, $100^{\circ} \mathrm{C}$. For many consumer battery applications, this is too hot to handle. ${ }^{40}$ 
Accordingly, fresh strategies are being tried in modern work. ${ }^{26}$ Other polymers are being mixed ${ }^{41}$ or copolymerized ${ }^{41-43}$ with poly(ethylene oxide) to give products having higher conductivity ${ }^{44}$; poly (propylene oxide) ${ }^{45}$<smiles>CC(C)CO</smiles>

polysiloxanes ${ }^{46}$

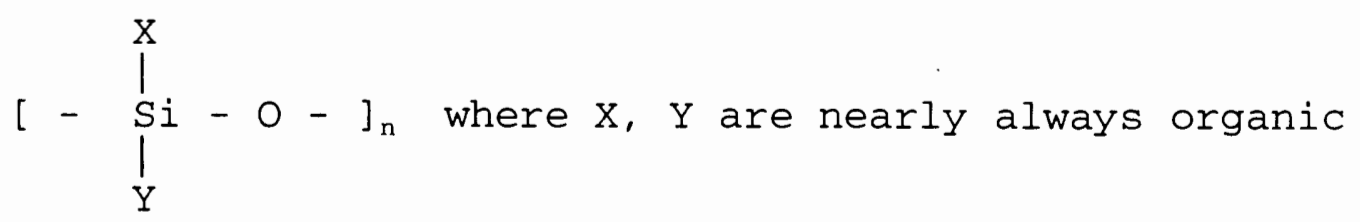
and poly (methacrylic acid) ${ }^{47}$<smiles>CC(C)(C)C(=O)O</smiles>

are examples. Poly (propylene oxide), a polymer that has been used nearly as long as PEO, is used unmixed as well. ${ }^{48}$ Polyphosphazenes ${ }^{49}$,

$$
\left[-\mathrm{PX}_{2}=\mathrm{N}-\right]_{\mathrm{n}} \quad(\mathrm{X}=\mathrm{alky}, \text { aryl, alkoxy, aryloxy })
$$

ethoxy-ethoxy-ethoxy vinyl ether polymers, 40

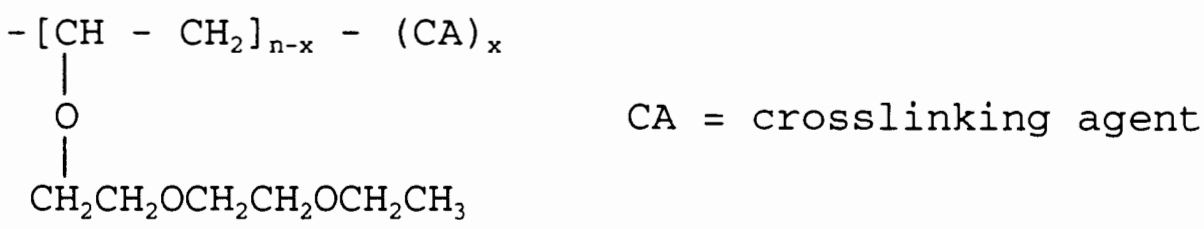

polyacrylamides 50

$$
\left[-\mathrm{CH}_{2}-\stackrel{\mathrm{CH}}{\mathrm{CONH}_{2}}\right]_{\mathrm{n}}
$$

and other polymers ${ }^{51}$ have been tried as well. Plasticizers 
42,48,50 and/or additives ${ }^{53}$ have been introduced to reduce crystallinity; cobalt-60 irradiation ${ }^{28}$ or treatment with light $^{54}$ have been employed to the same end.

Since the time when Armand suggested it, the main application for which polymer electrolytes have been groomed is batteries, ${ }^{23,28,55-57}$ specifically rechargeable solid state batteries. Many reasons exist for choosing polymer electrolytes for making batteries. ${ }^{23}$ There is no corrosive liquid to leak out, and no gas to be given off as the battery is used. This not only makes the solid state battery more convenient for the consumer, but simplifies the manufacturing process and thus brings manufacturing costs down.

The polymer electrolyte is not only more suitable than a liquid electrolyte, but better for use in a solid state rechargeable battery than a rigid solid electrolyte. The flexibility and adhesiveness of the polymer help it to remain in electrical contact with the electrodes through the changes in shape the electrodes experience in the course of operation. The metal anode develops cracks and thins out as the battery is being used, and fills out again during recharge. If a cathode that works by an intercalation mechanism ${ }^{6,8,56,58-60}\left(\mathrm{TiS}_{2}, \mathrm{~V}_{6} \mathrm{O}_{13}\right.$, etc.) is used, the cathode will expand during battery operation and contract during recharge. A solid electrolyte rigid in shape cannot maintain electrical contact, but a polymer electrolyte can. 
Compare the sodium-sulfur battery using the rigid sodium $\beta$ alumina as electrolyte: the electrodes must be kept in a molten state to maintain contact.

The power density for the battery can be made large by making the thickness of the polymer electrolyte layer small. With polymer electrolytes it is possible to make the thickness very small, possible to obtain a solid state battery that outstrips lead storage batteries and nickelcadmium batteries in performance.

Since the polymer electrolyte is effective in thin films, a wide variety of sizes and geometries for battery manufacture is possible. The amount of polymer electrolyte needed can be small, so the weight, volume and cost of the electrolyte can be small as well. This makes the batteries more portable, and allows a greater percentage of the total weight of the battery to be used for electrode materials.

Other uses for polymer electrolytes do exist besides batteries, however. Various electrochromic devices requiring the use of polymer electrolytes have been reviewed" example of these. Another application is in displays; these can be larger and visible from a greater range of viewing angles. 25.63 polymer electrolyte fuel cells $\mathrm{s}^{64,65}$ and fuel cell membranes ${ }^{66}$ are matters of interest. A polymer electrolyte electrode has even been tested for use in electrodeposition of tungsten from tungsten hexafluoride. ${ }^{67}$ 


\section{LITHIUM BATTERIES AND LITHIUM POLYMER ELECTROLYTES}

It is clear that polymer electrolytes may be capable of producing superior batteries. It remains to be shown why lithium polymer electrolytes specifically are desirable: lithium polymer electrolytes can be used as lithium solid state rechargeable batteries. Consider the following cell: ${ }^{2}$

$$
\begin{array}{cc}
\mathrm{Li} \rightarrow \mathrm{Li}^{+}+\mathrm{e}^{-} & \text {(Anode) } \\
\mathrm{TiS}_{2}+\mathrm{xLi}^{+}+\mathrm{xe}^{-} \rightarrow \mathrm{Li}_{\mathrm{x}} \mathrm{TiS}_{2} & \text { (Cathode) }
\end{array}
$$

Here we have lithium metal supplying the lithium ions and electrons; the lithium ions travel to the cathode through a lithium polymer electrolyte, then form the intercalation complex with the titanium sulfide. On recharge, the lithium ions leave their intercalation sites, run through the Iithium polymer electrolyte to the new cathode, and become lithium metal again. Lithium polymer electrolytes form the bridge by which lithium ions go from anode to cathode and back again.

Lithium metal is the key to the lithium battery's superiority. ${ }^{68}$ The voltage is higher $(3.9 \mathrm{~V})$ than the voltage of many conventional cells $(1.5 \mathrm{~V})$, and this is so because lithium metal has the lowest reduction potential of any metal. It is also the lightest of metals, and the number of electrons available per unit weight is greater than it is for any metal. The number of electrons available per unit volume is not as great for lithium as it is for aluminum or magnesium, but neither of these metals is as 
suitable as lithium. Lithium has greater mechanical strength than the other alkali metals, so it would make a better electrode material than they would.

Lithium batteries can function over a greater range of temperatures. As these batteries discharge, they keep a relatively constant voltage until they are nearly exhausted. Shelf lives of many years are frequent for lithium batteries.

So solid state lithium batteries are well worth investigating. A good lithium polymer electrolyte will help to make a good lithium battery; not all lithium polymer electrolytes are equally good at conducting current. Consequently each electrolyte has to be tested for suitability; there is as yet no theory of polymer electrolytes which will infallibly point out the ones which are best for the job.

The solubility of the lithium salt in question with the polymer in question is important; ${ }^{26}$ no solubility, no complex formation. The lattice energy of the salt, the entropy associated with solution, the energy required for the polymer to adjust to the presence of cations, and cation-anion attractive energies all play a part in this complicated process of solution. ${ }^{29}$ Shriver et al., point to the importance of lattice energy for the process: if the lattice energy is too high, no complex forms. ${ }^{29}$

Complexes can be formed from many different ratios of 
polymer to salt, and of course these do not conduct electricity with equal ease. Those complexes with small salt content do not conduct as well as some of the more concentrated ones do. Many complexes are very concentrated by ordinary chemical standards. Consequently there are many involved ion-polymer and ion-ion interactions present, ${ }^{28,29}$ making conductivity prediction difficult.

Aside from these reasons for testing polymer electrolytes, there remains another: electrochemical stability. ${ }^{28}$ Now one might assume that lithium and lithium salt employed would be stable together under the conditions of battery operation if they were stable together at $25^{\circ} \mathrm{C}$, but this is not always the case. Lithium metal has been found to react with lithium triflate ${ }^{28}--a$ surprising turn of events considering the great stability of the triflate ion. While the exact nature of the reaction is in question, one plausible explanation involves lithium sulfite formation: 26,28

$$
\mathrm{CF}_{3} \mathrm{SO}_{3} \mathrm{Li}+\mathrm{Li}_{(\mathrm{S})} \longrightarrow 2 \mathrm{Li}^{+}+\mathrm{SO}_{3}^{-2}+\mathrm{CF}_{3} \text {. }
$$

In order to show the extent of work already performed, a number of lithium salt complexes are shown in Table I. For each of the anions listed, one column gives the concentration of salt in the polymer in terms of moles of polymer oxygen to moles of salt lithium together with appropriate bibliographic reference, while the other gives the conductivity for that concentration at a specific 
temperature. A column of additional references also appears .

\section{Table I}

LITHIUM SALT COMPLEXES WITH POLY(ETHYLENE OXIDE)

\begin{tabular}{|c|c|c|c|}
\hline Anion & $\begin{array}{l}\text { PEO Oxygen to } \\
\text { Sait Lithium } \\
\text { Ratio }\end{array}$ & $\begin{array}{l}\text { Conductivity } \\
(\Omega \mathrm{cm})^{-1}\end{array}$ & References \\
\hline $\mathrm{Cl}^{-}$ & n.a. & n.a. & (27) \\
\hline $\mathrm{Br}$ & $4.5(68)$ & $10^{-5}\left(150^{\circ} \mathrm{C}\right)$ & (27) \\
\hline$r$ & $4.5(68)$ & $10^{-5}\left(85^{\circ} \mathrm{C}\right)$ & (27) \\
\hline $\mathrm{SCN}^{-}$ & $4.5(69)$ & $4 \times 10^{-5}\left(110^{\circ} \mathrm{C}\right)$ & -- \\
\hline $\mathrm{ClO}_{4}^{-}$ & $16(70)$ & $3 \times 10^{-4}\left(65^{\circ} \mathrm{C}\right) \max$ & $(27),(68),(71)$ \\
\hline $\mathrm{NO}_{3}{ }^{-}$ & $4.5(32)$ & $6 \times 10^{-6}\left(80^{\circ} \mathrm{C}\right) \max$ & -- \\
\hline $\mathrm{BF}_{4}^{-}$ & $4.5(68)$ & $10^{-5}\left(20^{\circ} \mathrm{C}\right)$ & $(27),(32)$ \\
\hline $\mathrm{B}\left(\mathrm{C}_{5} \mathrm{H}_{5}\right)_{4}^{\circ}$ & n.a. & n.a. & (27) \\
\hline $\mathrm{AsF}_{6}^{\circ}$ & $12(70)$ & $7 \times 10^{-5}\left(60^{\circ} \mathrm{C}\right)$ & (68) \\
\hline $\mathrm{Hgl}_{3}^{-}$ & n.a. & n.a. & (27) \\
\hline $\mathrm{CF}_{3} \mathrm{COO}$ & $9(72)$ & $2 \times 10^{-5}\left(105^{\circ} \mathrm{C}\right)$ & (32), (68) \\
\hline $\mathrm{C}_{2} \mathrm{~F}_{5} \mathrm{COO}$ & $9(72)$ & $10^{-4}\left(100^{\circ} \mathrm{C}\right)$ & - \\
\hline $\mathrm{C}_{3} \mathrm{~F}_{7} \mathrm{COO}$ & $9(72)$ & $9 \times 10^{-5}\left(100^{\circ} \mathrm{C}\right)$ & -. \\
\hline$\left(\mathrm{CF}_{2}\right)_{3}\left(\mathrm{COO}^{-}\right)_{2}$ & $9(72)$ & $2 \times 10^{-5}\left(100^{\circ} \mathrm{C}\right)$ & - \\
\hline $\mathrm{CF}_{3} \mathrm{SO}_{3}^{-}$ & $8(70)$ & $10^{-5}\left(60^{\circ} \mathrm{C}\right)$ & $\begin{array}{l}(32),(37),(68),(71 \\
),(72)\end{array}$ \\
\hline $\mathrm{C}_{6} \mathrm{~F}_{13} \mathrm{SO}_{3}^{-}$ & $4.5(68)$ & $10^{-5}\left(75^{\circ} \mathrm{C}\right)$ & - \\
\hline $\mathrm{N}\left(\mathrm{CF}_{3} \mathrm{SO}_{2}\right)_{2}^{-}$ & $16(73)$ & $10^{-3}\left(60^{\circ} \mathrm{C}\right)$ & $(71) \operatorname{cf}(53)(74)$ \\
\hline $\mathrm{C}\left(\mathrm{CF}_{3} \mathrm{SO}_{2}\right)_{3}^{\circ}$ & $11(73)$ & $10^{-3}\left(60^{\circ} \mathrm{C}\right)$ & $c f(53)$ \\
\hline
\end{tabular}


So the many kinds of lithium salts listed in Table I were tried for polymer electrolyte work; some are better than others. Perfluoroalkyl disulfonic acid dilithium salts have already been recommended by Bannister, Ward, Davies and McIntyre for conductivity investigation: ${ }^{74}$ these salts should be expected to have lithium transport numbers nearly equal to one.

In electrolyte salt solutions, part of the current is carried by the cation, part by the anion. A transport number, the fraction of the current carried by a given kind of ion, can be assigned to the cation and to the anion. The task is to find a lithium salt such that the lithium ion will carry almost all of the current. This can happen if the anion is a part of the polymer or if the anion is so bulky that it cannot move very fast through the polymer. ${ }^{74}$ 
CHAPTER II

SYNTHESIS

\section{General Considerations}

To achieve the task, three kinds of lithium-containing compounds were studied: (1) lithium salts of perfluoroalkane disulfonic acids, (2) lithium salts of $\mathrm{SF}_{5}$ containing sulfonic acids, and (3) a lithium salt of a polymeric sulfonic acid.

Ion pairing complicates the work. The more the cations and anions impede each other's motion, the less likely it will be for the cation to carry most of the charge. If anions can be tailor-made to minimize these pairings, then the task is accomplished. The trick is to create an anion having electron-withdrawing groups on it. The $\mathrm{CF}_{3} \mathrm{SO}_{2}^{-}$group is extremely electron-witharawing, ${ }^{75}$ and accordingly lithium salts like $\mathrm{LiN}\left(\mathrm{CF}_{3} \mathrm{SO}_{2}\right)_{2}$ and $\mathrm{LiC}\left(\mathrm{CF}_{3} \mathrm{SO}_{2}\right)_{3}$ have been prepared for polymer electrolyte work--and found to have high conductivities. $55,73,76,77$ These considerations make anions containing the extremely electron-witharawing $\mathrm{SF}_{5}$ group well worth investigating.

The perfluoroalkyl disulfonic acid disalts will have one lithium that will ionize more easily than the other. It is possible that the second lithium may form ion pairs with other new singly charged bulky anions, allowing the first 
Iithium to carry current with high transport number. ${ }^{74}$

New Fluorinated Lithium Salts

The technique of electrochemical fluorination can be employed to make a wide variety of compounds. ${ }^{78,79}$ After electrolysis with anhydrous hydrogen fluoride, a hydrogencontaining organic compound should yield a fluorinated compound with the same carbon skeleton.

Gramstad and Haszeldine were the first to apply this technique to alkyl sulfonyl fluorides; ${ }^{80}$ they were able to prepare and characterize a number of perfluorinated alkylsulfonic acids in this way:

$$
\begin{array}{ll}
\mathrm{RSO}_{2} \mathrm{~F} & \frac{\mathrm{HF}}{\text { electrolysis }} \mathrm{R}_{\mathrm{f}} \mathrm{SO}_{2} \mathrm{~F} \\
& \\
\mathrm{R}_{\mathrm{f}} \mathrm{SO}_{2} \mathrm{~F}+2 \mathrm{KOH} \longrightarrow \mathrm{R}_{\mathrm{f}} \mathrm{SO}_{2} \mathrm{OK}+\mathrm{KF}+\mathrm{H}_{2} \mathrm{O} \\
\mathrm{R}_{\mathrm{f}} \mathrm{SO}_{2} \mathrm{OK}+\mathrm{H}^{+} \longrightarrow \mathrm{R}_{\mathrm{f}} \mathrm{SO}_{2} \mathrm{OH}+\mathrm{K}^{+}
\end{array}
$$

Subsequent preparations of the disulfonic acids $\left(\mathrm{HOSO}_{2}\left(\mathrm{CF}_{2}\right)_{\mathrm{n}} \mathrm{SO}_{2} \mathrm{OH}\right.$ - for $\mathrm{n}=1,{ }^{81} \mathrm{n}=2,{ }^{82} \mathrm{n}=3,{ }^{83} \mathrm{n}=4,{ }^{82,83}$ $\mathrm{n}=6^{82}$ ) use the same general synthesis procedure-electrochemical fluorination of a sulfonyl halide followed by treatment with base followed by acidification--even though the details may vary.

The pentafluorothio alkyl sulfonic acids have a more complicated history, though many were prepared by Dr. Gard's group at PSU. ${ }^{84-88}$ The first was $\mathrm{SF}_{5} \mathrm{CHFSO} \mathrm{O}_{2} \mathrm{OH}$, made by the following procedure: 


$$
\begin{gathered}
\mathrm{SF}_{5} \mathrm{CF}=\mathrm{CF}_{2}+\mathrm{SO}_{3} \longrightarrow \frac{\Delta}{\mathrm{SF}_{5}-\mathrm{CF}-\mathrm{CF}_{2}} \\
\left.\right|_{\mathrm{SO}_{2}-\mathrm{O}} ^{\longrightarrow} \\
\quad \mathrm{SF}_{5}-\mathrm{CF}-\mathrm{CF}_{5}+\mathrm{CHFSO}_{2} \mathrm{~F}+\mathrm{CH}_{2} \mathrm{O} \longrightarrow \mathrm{CO}+\mathrm{HF}
\end{gathered}
$$

The resulting sulfonyl fluoride can then be treated with base and acidified to give $\mathrm{SF}_{5} \mathrm{CHFSO}_{2} \mathrm{OH} .{ }^{84}$

The sulfonyl fluoride was later treated with fluorine: $\mathrm{SF}_{5} \mathrm{CHFSO}_{2} \mathrm{~F}+\mathrm{F}_{2}+\mathrm{NaF}$ $\mathrm{SF}_{5} \mathrm{CF}_{2} \mathrm{SO}_{2} \mathrm{~F}+\mathrm{NaHF}_{2}$

to yield a sulfonyl fluoride from which $\mathrm{SF}_{5} \mathrm{CF}_{2} \mathrm{SO}_{2} \mathrm{OH}$ was prepared by reaction with base then acid. ${ }^{85}$

Another $\mathrm{SF}_{5}$ sulfonic acid was synthesized as follows:

$$
\begin{aligned}
& \mathrm{SF}_{5} \mathrm{CH}=\mathrm{CF}_{2}+\mathrm{SO}_{3} \longrightarrow \mathrm{SF}_{5} \mathrm{CH}-\mathrm{SO}_{\mathrm{SO}_{2}-} \mathrm{CF}_{2}
\end{aligned}
$$

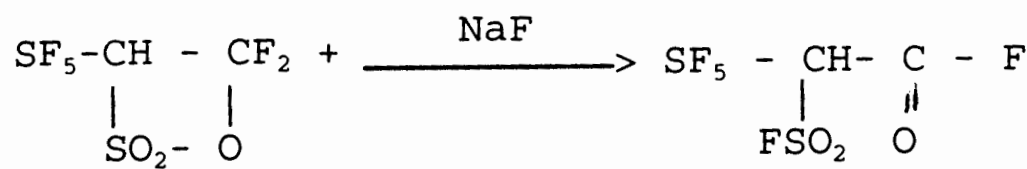

$$
\begin{aligned}
& \mathrm{SF}_{5}-\mathrm{CH}-\mathrm{C}-\mathrm{F}+\mathrm{H}_{2} \mathrm{O} \longrightarrow \mathrm{SF}_{5} \mathrm{CH}_{2} \mathrm{SO}_{2} \mathrm{~F}+\mathrm{HF}+\mathrm{CO}_{2} \\
& \mathrm{~F}-\mathrm{SO}_{2} \mathrm{O}
\end{aligned}
$$

and this sulfonyl fluoride could likewise be reacted successively with base and then with acid to give $\mathrm{SF}_{5} \mathrm{CH}_{2} \mathrm{SO}_{2} \mathrm{OH} \cdot{ }^{86}$

Two carbon pentafluorothiosulfonic acids, $\mathrm{SF}_{5} \mathrm{CHXCY}_{2} \mathrm{SO}_{2} \mathrm{OH}$ $(X, Y=H, F)$, have also been produced:

$$
\mathrm{SF}_{5} \mathrm{CHXCY}_{2} \mathrm{Br}+\mathrm{Na}_{2} \mathrm{SO}_{3} \frac{508 \mathrm{EtOH}}{\text { reflux }} \mathrm{SF}_{5} \mathrm{CHXCY}_{2} \mathrm{SO}_{3} \mathrm{Na}+\mathrm{NaBr}
$$

These sodium salts react with $\mathrm{HCl}$ to give the sulfonic 
acids. ${ }^{87,88}$

The ether salt's acid, 2,2'-Oxybis $(1,1,2,2-$ tetrafluoroethane-sulfonic acid), was prepared for the first time using a procedure far less straightforward than that employed for straight chain disulfonic acids: ${ }^{89}$

$$
\mathrm{CF}_{2}=\mathrm{CF}_{2}+\mathrm{SO}_{3} \longrightarrow \underset{\mathrm{SO}_{2}-0}{\mathrm{CF}_{2}-\mathrm{CF}_{2}}
$$

$$
\underset{\mathrm{SO}_{2}-0}{\mathrm{CF}_{2}-\mathrm{CF}_{2}} \frac{\mathrm{ICl}, \mathrm{CF}_{2}=\mathrm{CF}_{2}}{\mathrm{KF}} \longrightarrow \mathrm{ICF}_{2} \mathrm{CF}_{2} \mathrm{OCF}_{2} \mathrm{CF}_{2} \mathrm{SO}_{2} \mathrm{~F}
$$

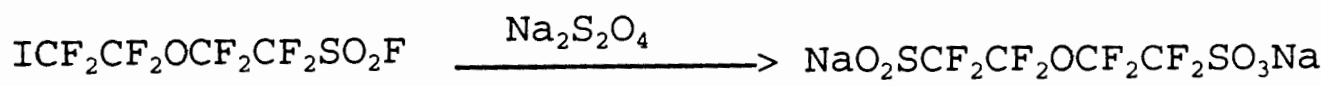

$$
\begin{aligned}
& \mathrm{NaO}_{2} \mathrm{SCF}_{2} \mathrm{CF}_{2} \mathrm{OCF}_{2} \mathrm{CF}_{2} \mathrm{SO}_{3} \mathrm{Na} \stackrel{\mathrm{Cl}_{2}}{\longrightarrow} \mathrm{ClO}_{2} \mathrm{SCF}_{2} \mathrm{CF}_{2} \mathrm{OCF}_{2} \mathrm{CF}_{2} \mathrm{SO}_{3} \mathrm{Na} \\
& \mathrm{ClO}_{2} \mathrm{SCF}_{2} \mathrm{CF}_{2} \mathrm{OCF}_{2} \mathrm{CF}_{2} \mathrm{SO}_{3} \mathrm{Na} \longrightarrow \mathrm{NaOH}
\end{aligned}
$$

$$
\begin{aligned}
& \left(\mathrm{NaO}_{3} \mathrm{SCF}_{2} \mathrm{CF}_{2}\right)_{2} \mathrm{O} \stackrel{\text { Amberlite IR-120 }}{\longrightarrow}\left(\mathrm{HOSO}_{2} \mathrm{CF}_{2} \mathrm{CF}_{2}\right)_{2} \mathrm{O} \\
& \text { The polymer } \\
& \text { T7A }
\end{aligned}
$$

was made into a lithium salt, was likewise prepared from tetrafluoroethylene sultone:

$$
\begin{aligned}
& \mathrm{CF}_{2}-\mathrm{CF}_{2}+\overparen{\mathrm{OCH}_{2}-\mathrm{CH}}-\mathrm{CH}_{2}-\mathrm{Br} \longrightarrow \\
& \mathrm{SO}_{2}-\mathrm{O} \\
& \mathrm{OCH}_{2}-\mathrm{CH}-\mathrm{CH}_{2}-\mathrm{O}-\mathrm{CF}_{2} \mathrm{CF}_{2} \mathrm{SO}_{2} \mathrm{~F} \longrightarrow \text { Acid Polymer } \\
& \text { / } \mathrm{CH}_{2}-\mathrm{O}-\mathrm{CF}_{2} \mathrm{CF}_{2} \mathrm{SO}_{2} \mathrm{~F} \stackrel{2 / \mathrm{n} \mathrm{LiOH}}{\longrightarrow} \\
& 1 / \mathrm{n}\left(-\mathrm{O}-\mathrm{CH}_{2}-\mathrm{CH}-\right)_{\mathrm{n}}
\end{aligned}
$$


$1 / \mathrm{n}\left(-\mathrm{O}-\mathrm{CH}_{2}-\stackrel{/}{\mathrm{CH}}-\right)_{\mathrm{n}}$

$$
\mathrm{CH}_{2}-\mathrm{O}-\mathrm{CF}_{2} \mathrm{CF}_{2} \mathrm{SO}_{2} \mathrm{OLi}
$$

Using the above schemes, a number of fluorinated

lithium salts have been prepared and characterized (IR, NMR, Mass Spectrum). These results are discussed in Chapter IV.

Dr. Michael Lerner and his research team at Oregon State University have used impedance analysis, differential scanning calorimetry and gel permeation chromatography to test the suitability of some of the salts prepared for use in poly (ethylene oxide) polymer electrolytes. Some of the results are discussed in Chapter VI. 
CHAPTER III

\section{EXPERIMENTAL}

\section{APPARATUS: VACUUM IINE}

A single manifold evacuated by means of a vacuum pump operating in conjunction with a liquid nitrogen cold trap provided the means for manipulation of samples of gases and low-boiling liquids. The manifold was made of $25 \mathrm{~mm}$ inside diameter Pyrex tubing fitted with four ports. Each port could be opened or closed with an Eck and Krebs $2 \mathrm{~mm}$ highvacuum stopcock, and vessels or tubing could be attached to a port by means of a 10/30 Pyrex standard taper ground glass outer joint. A Welch Duo-seal rotary pump provided the vacuum. The Frederick Company Televac thermocouple gauge was used to read the pressure in the 1-100 micron range, while a mercury manometer was used to measure pressures in the 10-760 mm Hg range. Fisher Scientific Fluorolube GR-290 or Arthur Thomas' Lubriseal grease were used to Iubricate joints and stopcocks; connections requiring a wax seal were obtained using Halocarbon Corporation's Halocarbon wax.

\section{Reaction Vessels}

Some reactions were carried out in $100 \mathrm{ml}$ Pyrex glass reaction vessels, to which a Kontes high-vacuum valve was attached. The valve may be closed to seal the vessel, or opened to allow connection with the outside through a Pyrex 
10/30 standard taper ground glass inner joint. This Teflon valve is seated on Viton O-rings, and a Teflon magnetic stirring bar sealed inside the vessel allows agitation of the reaction mixture.

\section{Instrumentation and Characterization}

A Nicolet 20-DX FT-IR spectrometer was used for recording infrared spectra from $4600-400 \mathrm{~cm}^{-1}$. This instrument has a $2.0 \mathrm{~cm}^{-1}$ resolution. Solid samples were pelletized with $\mathrm{KBr}$ for analysis, while liquids, with or without solvent, were smeared on $\mathrm{NaCl}$ plates. Gas samples were run in a cell with $\mathrm{KBr}$ windows; the cell path length was $10 \mathrm{~cm}$.

The ${ }^{1} \mathrm{H},{ }^{19} \mathrm{~F}$ and ${ }^{13} \mathrm{C}$ nuclear magnetic resonance spectra were obtained from two instruments. A Varian EM-390 spectrometer was used at $90.00 \mathrm{MHz}$ for proton samples and at 84.67 MHz for fluorine samples. A Bruker AMX-400 instrument operating at $400 \mathrm{MHz}$ for ${ }^{1} \mathrm{H}, 376.8 \mathrm{MHz}$ for ${ }^{19} \mathrm{~F}$, and $100 \mathrm{MHz}$ for ${ }^{13} \mathrm{C}$ was employed as well. The standard for ${ }^{1} \mathrm{H}$ and ${ }^{13} \mathrm{C}$ resonances was TMS $\left(\left(\mathrm{CH}_{3}\right)_{4} \mathrm{Si}\right)$, while the ${ }^{19} \mathrm{~F}$ standard was Freon F-11 $\left(\mathrm{CFCl}_{3}\right)$. When the Bruker was used for fluorine work, a $\mathrm{D}_{2} \mathrm{O}$ lock was used instead of an internal standard. Downfield is taken as the positive direction for the reporting of fluorine resonance values.

The mass spectrometric work was accomplished using either a Varian MAT CH5 or a Finnigan MAT 8230 system operating at $70 \mathrm{eV}$. These analyses were performed at the 
Institut für Anorganische und Physicalische Chemie at the University of Bremen, Germany.

Elemental analyses were performed by Beller Mikroanalytisches Laboratorium, Göttingen, Germany.

A Mel Temp melting point apparatus was used for the determination of melting points. Melting points and boiling points are reported uncorrected.

\section{Dry Box}

A Vacuum Atmospheres Corporation Dri-Lab HE-43-2 was used for the manipulation of moisture sensitive materials. Nitrogen gas, dried over heated molecular sieve, is used as the dry box atmosphere; oxygen control was never needed for our experiments. Moisture was kept below $10 \mathrm{ppm}$, the point at which titanium tetrachloride begins to fume in moist $\operatorname{air} .{ }^{92}$

\section{Reagents}

The $\mathrm{SF}_{5} \mathrm{CH}_{2} \mathrm{CH}_{2} \mathrm{SO}_{2} \mathrm{ONa}$, $\mathrm{SF}_{5} \mathrm{CH}_{2} \mathrm{CF}_{2} \mathrm{SO}_{2} \mathrm{ONa}, \mathrm{SF}_{5} \mathrm{CHFCF}_{2} \mathrm{SO}_{2} \mathrm{ONa}$ and their corresponding acids were prepared by Robert $\mathrm{J}$. Willenbring. ${ }^{87}$

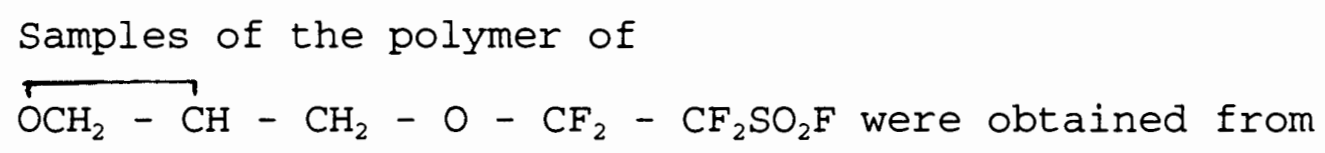

Nicolas N. Hamel, Li-Fo Chen and N. Robert Holcomb. Mr. Hamel also supplied some $\mathrm{Ag}_{2} \mathrm{O}$.

A sample of $\left(\mathrm{CF}_{2} \mathrm{SO}_{2} \mathrm{OK}\right)_{2}$ was prepared electrolytically by Philip Ross of the Lawrence Berkeley Laboratory in Berkeley, 
California.

A number of reagents were obtained from Dr. Fred Behr of $3 \mathrm{M}$ Company, among them: $\mathrm{CF}_{2}\left(\mathrm{SO}_{2} \mathrm{O}\right){ }_{2} \mathrm{Ba}(3 \mathrm{M}: \mathrm{L}-5428)$, $\left(\mathrm{CF}_{2} \mathrm{SO}_{2} \mathrm{OK}\right)_{2}(3 \mathrm{M}: \mathrm{L}-5433), \mathrm{CF}_{2}\left(\mathrm{CF}_{2} \mathrm{SO}_{2} \mathrm{OK}\right)_{2}$ (3M: no experimental product number), $\left(\mathrm{CF}_{2} \mathrm{CF}_{2} \mathrm{SO}_{2} \mathrm{O}\right)_{2} \mathrm{Ca}(3 \mathrm{M}: \mathrm{L}-9123)$, $\left(\mathrm{CF}_{2} \mathrm{CF}_{2} \mathrm{CF}_{2} \mathrm{SO}_{2} \mathrm{O}_{2}\right)_{2} \mathrm{Ca}(3 \mathrm{M}: \mathrm{L}-10120), \mathrm{Ca}\left(\mathrm{OSO}_{2} \mathrm{CF}_{2} \mathrm{CF}_{2}\right)_{2} \mathrm{O} \quad(3 \mathrm{M}: \mathrm{L}-$ 9511), $\mathrm{C}_{8} \mathrm{~F}_{17} \mathrm{SO}_{2} \mathrm{~F}$ (3M: Fluorad FX-8, Lot Number 98-0211-15344) $\mathrm{FO}_{2} \mathrm{~S}\left(\mathrm{CF}_{2}\right)_{4} \mathrm{SO}_{2} \mathrm{~F}(3 \mathrm{M}: \mathrm{L}-11277)$.

From Aldrich Chemical Co.: $\mathrm{LiOH} \cdot \mathrm{H}_{2} \mathrm{O}$ (99.958), LiCl $(99.99+\%), \quad\left(\mathrm{CH}_{3}\right)_{3} \mathrm{SiOSO}_{2} \mathrm{CF}_{3}(96 \%), \operatorname{LiOSi}\left(\mathrm{CH}_{3}\right)_{3}(97 \%)$, $\mathrm{AgOSO}_{2} \mathrm{CF}_{3}(99+\%)$. From Mallinckrodt Chemical Co. were: $\mathrm{AgNO}_{3}$ (AR Grade) and $\mathrm{Li}_{2} \mathrm{SO}_{4} \cdot \mathrm{H}_{2} \mathrm{O}$ (Reagent Grade). From Matheson, Coleman and Bell was: $\mathrm{LiOH} \cdot \mathrm{H}_{2} \mathrm{O}$ (Reagent Grade). From Chemonics was: $30 \% \mathrm{H}_{2} \mathrm{O}_{2}$, stabilized (Reagent Grade).

The ion exchange material used was Rohm and Haas' Amberlite IR-120 resin from Mallinckrodt.

The poly (ethylene oxide), M.W. $5 \times 10^{6}$, was obtained from Aldrich Chemicals.

The solvents employed were:

$\mathrm{CH}_{3} \mathrm{OH}$, Amachem, Anhydrous reagent grade;

$\mathrm{CH}_{3} \mathrm{OH}$, Mallinckrodt (AR), and Dewey Products Co.

(ACS Grade)-Fifty $\mathrm{ml}$ of $\mathrm{CH}_{3} \mathrm{OH}, 5 \mathrm{~g}$ of magnesium turnings and $0.5 \mathrm{~g}$ resublimed $\mathrm{I}_{2}$ (Mallinckrodt, AR grade) were refluxed together until gas appeared, then a liter of the combined manufactures of methanol was added. After 0.5 hr the material was distilled and the fraction boiling at $66.5-67^{\circ} \mathrm{C}$ 
was recovered and used.

$\mathrm{C}_{6} \mathrm{H}_{5} \mathrm{CH}_{3}$-Mallinckrodt, AR Grade-Distilled over sodium after an hour's refluxing.

$\mathrm{CH}_{3} \mathrm{CN}$-Baker HPLC Grade-A $130 \mathrm{ml}$ portion was predried with $\mathrm{MgSO}_{4}$, refluxed with $0.7 \mathrm{~g} \mathrm{CaH}_{2}$ for an hour, then distilled. The first $6 \mathrm{ml}$ were rejected; the portion boiling $80.8-81.2^{\circ} \mathrm{C}$ was collected.

Tetrahydrofuran-Aldrich 99+8-Dried with Linde Molecular Sieve $4 \mathrm{~A}$. 


\section{PREPARATION OF LITHIUM SULFONATES}

\section{DISCUSSION}

All the pentafluorothio-and perfluoroalkane sulfonic acid lithium salts prepared here have been made from precursors that are mostly salts of the same acids. The $\mathrm{SF}_{5}$ sulfonic acids and sodium salts prepared by Robert $J$. Willenbring ${ }^{88}$ were the source for the two carbon sulfonic acid lithium salts:

$$
\mathrm{SF}_{5} \mathrm{CHXCY}_{2} \mathrm{SO}_{2} \mathrm{ONa} \stackrel{\text { ion exchange }}{\longrightarrow} \mathrm{SF}_{5} \mathrm{CHXCY}_{2} \mathrm{SO}_{2} \mathrm{OH}
$$

$(X, Y=H, F) \quad \mathrm{SF}_{5} \mathrm{CHXCY}_{2} \mathrm{SO}_{2} \mathrm{OH}+\mathrm{LiOH}$

$$
\mathrm{SF}_{5} \mathrm{CHXCY}_{2} \mathrm{SO}_{2} \mathrm{OLi}+\mathrm{H}_{2} \mathrm{O}
$$

The potassium, calcium and barium perfluoroalkane disulfonic acid disalts provided by Dr. Fred Behr of $3 \mathrm{M}$ Company were used to make the corresponding lithium salts:

$$
\begin{aligned}
& \mathrm{Ba}\left(\mathrm{OSO}_{2}\right)_{2} \mathrm{CF}_{2}+\mathrm{Li}_{2} \mathrm{SO}_{4} \longrightarrow \mathrm{CF}_{2}\left(\mathrm{SO}_{2} \mathrm{OLi}\right)_{2}+\mathrm{BaSO}_{4} \\
& \mathrm{KOSO}_{2}\left(\mathrm{CF}_{2}\right)_{\mathrm{n}} \mathrm{SO}_{2} \mathrm{OK} \stackrel{\text { ion exchange }}{\longrightarrow} \mathrm{HOSO}_{2}\left(\mathrm{CF}_{2}\right)_{\mathrm{n}} \mathrm{SO}_{2} \mathrm{OH} \\
& \begin{aligned}
2 \mathrm{LiOH}+ & \mathrm{HOSO}_{2}\left(\mathrm{CF}_{2}\right)_{\mathrm{n}} \mathrm{SO}_{2} \mathrm{OH} \longrightarrow \mathrm{LiOSO}_{2}\left(\mathrm{CF}_{2}\right)_{\mathrm{n}} \longrightarrow \mathrm{SO}_{2} \mathrm{OLi}+2 \mathrm{H}_{2} \mathrm{O} \\
\mathrm{n} & =2,3
\end{aligned}
\end{aligned}
$$




$$
\begin{aligned}
& 2 \mathrm{LiOH}+\left(\mathrm{HOSO}_{2} \mathrm{CF}_{2} \mathrm{CF}_{2}\right)_{2} \longrightarrow\left(\mathrm{LiOSO}_{2} \mathrm{CF}_{2} \mathrm{CF}_{2}\right)_{2} \\
& 2 \mathrm{LiOH}+\left(\mathrm{HOSO}_{2} \mathrm{CF}_{2} \mathrm{CF}_{2}\right)_{2} \mathrm{O} \longrightarrow\left(\mathrm{LiOSO}_{2} \mathrm{CF}_{2} \mathrm{CF}_{2}\right)_{2} \mathrm{O}
\end{aligned}
$$

Another kind of lithium sulfonate was prepared, this one from a polymer:

$$
\begin{gathered}
{\left[-\left(\mathrm{FSO}_{2} \mathrm{CF}_{2} \mathrm{CF}_{2} \mathrm{OCH}{ }_{2}\right) \mathrm{CH}-\mathrm{CH}_{2}-\mathrm{O}-\right]_{\mathrm{n}}+2 \mathrm{nLiOH}} \\
{\left[-\left(\mathrm{LiOSO}_{2} \mathrm{CF}_{2} \mathrm{CF}_{2} \mathrm{OCH}_{2}\right) \mathrm{CH}-\mathrm{CH}_{2}-\mathrm{O}-\right]_{\mathrm{n}}+\mathrm{nH}_{2} \mathrm{O}+\mathrm{nLiF}^{85,89,94}}
\end{gathered}
$$

The question of which of the pentafluorothio alkyl and perfluoroalkane sulfonic acid salts would be the best for testing as lithium polymer electrolytes revolves around two principal factors. High molecular weights are desirable for such salts; the heavy anion will not move very fast, and so allow the small lithium ion to carry most of the current.

On the other hand, these salts become less and less polar as their molecular weights increase. This means that they will become less and less soluble in the polar poly(ethylene oxide). Samples of the disulfonic acid dilithium salts were subjected to an appropriate test for solubility in the very polar solvent, water. A weighed portion of salt sample was placed in a tared beaker and water was slowly added with stirring until the sample just dissolved. A second weighing of the beaker gives the weight of the water added, and consequently the strength of the resulting solution. The one-carbon salt was soluble to the extent of $\sim 56 \mathrm{~g} / \mathrm{L}$; the two-carbon salt, $\sim 80 \mathrm{~g} / \mathrm{L}$; the threecarbon salt, $\sim 32 \mathrm{~g} / \mathrm{L}$; the four-carbon salt, $-55 \mathrm{~g} / \mathrm{L}$; and the six-carbon salt $-5.6 \mathrm{~g} / \mathrm{L}$. It is clear that after four 
carbons, the solubility of the disalts drops off appreciably.

Likewise the one-carbon $\mathrm{SF}_{5}$ salts $\left(\mathrm{SF}_{5} \mathrm{CHFSO}_{2} \mathrm{OLi}\right.$ and $\mathrm{SF}_{5} \mathrm{CF}_{2} \mathrm{SO}_{2} \mathrm{OLi}$ ) were prepared by Nicolas $\mathrm{N}$. Hamel. ${ }^{95}$ $\mathrm{SF}_{5} \mathrm{CFXSO}_{2} \mathrm{~F}+2 \mathrm{IiOH} \longrightarrow \mathrm{SF}_{5} \mathrm{CFXSO}_{2} \mathrm{OLi}+\mathrm{LiF}+\mathrm{H}_{2} \mathrm{O} ; \mathrm{x}=\mathrm{H}, \mathrm{F}$ (20)

The two carbon $\mathrm{SF}_{5}$ salts prepared as described above, and the ether salt $\mathrm{O}\left(\mathrm{CF}_{2} \mathrm{CF}_{2} \mathrm{SO}_{2} \mathrm{OLi}\right)_{2}$ were readied for testing. The bulky $\mathrm{SF}_{5}$ group will probably prevent the anions from moving much current.

A number of methods were employed for preparing the desired lithium salts. In one method, the salts were prepared by converting an available salt into its corresponding acid, then neutralizing the acid with lithium hydroxide. Gramstad and Haszeldine used concentrated sulfuric acid to prepare their perfluoroalkane sulfonic acids, ${ }^{80}$ but this method is harsh; some acid samples have been known to char with this powerful dehydrating agent upon heating. ${ }^{88}$

Ion exchange resins ${ }^{96-98}$ were employed to make acids out of salts:

$$
\begin{aligned}
& \mathrm{MA} \stackrel{\text { ion exchange }}{\longrightarrow} \mathrm{M}^{+}+\mathrm{HA} \\
& \mathrm{LiOH}+\mathrm{HA} \longrightarrow \mathrm{LiA}+\mathrm{H}_{2} \mathrm{O}
\end{aligned}
$$

(Here $M$ is some metal and $A^{-}$some anion.) Ion exchange has been put to use in making perfluoroalkane disulfonic acids. ${ }^{81.82}$ Consequently, Rohm and Haas' Amberlite IR-120, a 
strongly acidic polystyrene sulfonic acid resin ${ }^{96}$ was employed in the acid form for these preparations.

The ion exchange process worked as follows: when the Amberlite resin is in its acid form, large numbers of hydrogen-bearing sulfonate groups in the polystyrene chain are available for reaction.

If a potassium or calcium salt solution is passed through the resin, the hydrogens on the resin are preferentially displaced by the incoming cations. If the number of hydrogen-bearing groups is in great excess, the conversion to acid is essentially quantitative. Since there is no heating involved in the process, the acid does not decompose. This ion exchange method is an excellent means of preparing acids.

Once the acids are formed, they can be made into salts by neutralization. Since these sulfonic acids are strong acids, adding base until the solution $\mathrm{pH}$ is near 7.0 was an acceptable means of neutralization.

A major problem of the project turned out to be drying the salts prepared in aqueous solution; lithium salts are hygroscopic. ${ }^{100}$

The first volume reduction for the aqueous lithium salt solutions made by neutralization could be effected on a rotary evaporator, or by slow evaporation at $40^{\circ} \mathrm{C}$. Removing the remaining water under vacuum is a delicate operation: bumping, with great loss of sample, can result. It is 
better to freeze the solution first, and then apply the vacuum as the solution is gradually warmed to room temperature. Removal of water then takes place at a slower rate, and loss due to bumping is minimized. Such a procedure will be referred to as "freeze drying" in the preparative descriptions that follow.

\section{ION EXCHANGE RESIN CAPACITY TEST}

Before any work could be done with the Rohm and Haas Amberlite IR-120 polystyrene sulfonate ion exchange resin, a resin capacity would have to be taken so that some idea of the number of moles of salt that can be converted to acid form by a given amount of resin might be known. If there is not enough resin, the conversion of a salt to the salt's corresponding acid may be incomplete; a large excess of available hydrogens form the resin is obviously desirable to ensure quantitative conversion.

Since the displacement of one cation on an ion exchange resin by another is an equilibrium process, ion exchange work is carried out in cylindrical columns. In this way the total volume of cation solution and the total volume of ion exchange resin in the column are effectively broken up into many cylindrical volume elements: each volume element of solution can establish a new equilibrium with each volume of resin it encounters as it flows slowly toward the bottom of the column. If there is a great enough excess of resin, the last volume element of cation solution poured into the 
column will have met enough volume elements of fresh resin to reduce the concentration of the cation in the solution to negligible levels. An essentially quantitative conversion will then have been achieved through an equilibrium process. The ASTM salt splitting capacity test was used. ${ }^{99}$ In this test a $10.0 \mathrm{~g}$ sample of wet ion exchange resin is converted to acid form with diluted hydrochloric acid. A liter of $50.0 \mathrm{~g} / \mathrm{L}$ sodium chloride solution is passed over the resin sample, and the acid-laden effluent is titrated with standardized $0.100 \mathrm{M}$ sodium hydroxide solution. The higher the acidity of the effluent, the better the resin is at releasing its acid.

Salt Splitting Capacity=

$$
\begin{aligned}
& \frac{\text { (ml NaOH solution) (normality of } \mathrm{NaOH} \text { ) (10) }}{\text { (weight of resin sample used) }} \\
& \text { Units: milliequivalent/wet gram }
\end{aligned}
$$

For our resin sample, the capacity was found to be 1.66 milliequivalents/wet gram.

There were two columns used for ion exchange work: a small column (about $30 \mathrm{~cm}$ long, $1 \mathrm{~cm}$ diameter) containing about $25 \mathrm{ml}$ of resin for the $\mathrm{SF}_{5}$ salts and a larger one (about $56 \mathrm{~cm}$ long, $1.6 \mathrm{~cm}$ diameter) containing about $70 \mathrm{ml}$ of resin for the disalts. The wet resin from the smaller column was found to weigh $30.88 \mathrm{~g}$; this corresponds to 51.4 milliequivalents of $\mathrm{H}$, or 0.0514 moles when used with monobasic salts. The smaller column was used for the conversion of 0.0020 moles $\mathrm{SF}_{5} \mathrm{CH}_{2} \mathrm{CH}_{2} \mathrm{SO}_{3} \mathrm{Na}, 0.0018$ moles 
$\mathrm{SF}_{5} \mathrm{CH}_{2} \mathrm{CF}_{2} \mathrm{SO}_{3} \mathrm{Na}$, and 0.0011 moles $\mathrm{SF}_{5} \mathrm{CHFCF}_{2} \mathrm{SO}_{3} \mathrm{Na}$ to the corresponding acid; it is clear that there is a great excess of acid form ion exchange resin.

Likewise $70 \mathrm{ml}$ of this same resin would be equivalent to 144 milliequivalents of $\mathrm{H}$, or 0.0720 moles of dibasic salts. This is more than enough capacity for the 0.0106 moles $\mathrm{CF}_{2}\left(\mathrm{CF}_{2} \mathrm{SO}_{2} \mathrm{OK}\right)_{2}, 0.0126$ moles $\left(\mathrm{CF}_{2} \mathrm{CF}_{2} \mathrm{SO}_{2} \mathrm{O}\right) \mathrm{Ca}$, or 0.0120 moles $\mathrm{O}\left(\mathrm{CF}_{2} \mathrm{CF}_{2} \mathrm{SO}_{2} \mathrm{O}\right) \mathrm{Ca}$ converted to acid in the larger column. A 0.0316 mole sample of $\left(\mathrm{CF}_{2} \mathrm{SO}_{2} \mathrm{OK}\right)_{2}$ was converted to acid using $140 \mathrm{ml}$ of resin (0.144 moles); again, the acid form of the resin is in great excess.

\section{SYNTHESIS OF $\mathrm{SF}_{5} \mathrm{CH}_{2} \mathrm{CH}_{2} \mathrm{SO}_{2} \mathrm{OLi}$}

A $0.51 \mathrm{~g}$ portion of $\mathrm{SF}_{5} \mathrm{CH}_{2} \mathrm{CH}_{2} \mathrm{SO}_{2} \mathrm{ONa}$ ( 0.0020 moles), that had previously been prepared by Robert $\mathrm{J}$. Wilenbring, was dissolved in $-10 \mathrm{ml}$ of water. This solution was passed through a small column, $25 \mathrm{ml}$, of Amberlite IR-120 in the acid form over a period of $\sim 0.5 \mathrm{hr}$, and the column was afterwards washed with three bed volumes of water $(75 \mathrm{ml})$. Using a pH meter (Corning Model 7 ), the acid solution was slowly neutralized with $\mathrm{LiOH} \cdot \mathrm{H}_{2} \mathrm{O}$ solution (MCB: ACS Grade) to $\mathrm{pH}$ 7.3. The volume of the solution was reduced by rotary evaporation; this solution was then transferred to a $10 \mathrm{ml}$ round bottomed flask. The solution was then freeze dried to a white fluffy powder $(0.43 \mathrm{~g})$; yield: $90 \%$. The sample was dried over $\mathrm{P}_{4} \mathrm{O}_{10}$ for ten days at room temperature. A portion 
of sample turns brown at $290^{\circ} \mathrm{C}$.

$$
\text { SYNTHESIS OF } \mathrm{SF}_{5} \mathrm{CH}_{2} \mathrm{CF}_{2} \mathrm{SO}_{2} \mathrm{OLi}
$$

A $0.53 \mathrm{~g}$ sample of $\mathrm{SF}_{5} \mathrm{CH}_{2} \mathrm{CF}_{2} \mathrm{SO}_{2} \mathrm{ONa}(0.0018$ moles) was dissoved in $\sim 5 \mathrm{ml}$ of water. This solution was slowly poured through a small column of Amberlite IR-120 (25 $\mathrm{ml})$ in the acid form over a period of $\sim .5 \mathrm{hr}$. , and the column was afterwards rinsed with three bed volumes of water $(75 \mathrm{ml})$. The acid solution was then neutralized with $\mathrm{LiOH} \cdot \mathrm{H}_{2} \mathrm{O}$ (MCB:ACS Grade) to $\mathrm{pH}$ 6.8. The solution was reduced in volume as above, then freeze dried in a $50 \mathrm{ml}$ round bottomed flask to a brownish white powder $(0.30 \mathrm{~g})$; Yield: $63 \%$. The sample was dried for ten days over $\mathrm{P}_{4} \mathrm{O}_{10}$. A portion of the sample turns brown at $258^{\circ} \mathrm{C}$.

\section{SYNTHESIS OF $\mathrm{SF}_{5} \mathrm{CHFCF}_{2} \mathrm{SO}_{2} \mathrm{OLi}$}

A $0.33 \mathrm{~g}(0.0011$ moles $)$ portion of $\mathrm{SF}_{5} \mathrm{CHFCF}_{2} \mathrm{SO}_{2} \mathrm{ONa}$ was dissoved in $-5 \mathrm{ml}$ of water. The resulting solution was run for $0.5 \mathrm{hr}$. through a small column of acid form Amberlite IR-120 (25 ml). Three bed volumes of water were used $(75 \mathrm{ml})$ to wash the column. Solution and washings were then neutralized with $\mathrm{LiOH} \cdot \mathrm{H}_{2} \mathrm{O}$ (MCB:ACS Grade) to $\mathrm{pH}$ 6.9. The salt solution was reduced in volume by rotary evaporation, then freeze dried in a $25 \mathrm{ml}$ round bottomed flask. The white powder resulting $(0.36 \mathrm{~g})$ represented a $99 \%$ yield; it was then further dried for 10 days over $\mathrm{P}_{4} \mathrm{O}_{10}$. The point at 
which a sample of this compound turned brown was $231^{\circ} \mathrm{C}$.

$$
\text { SYNTHESIS OF } \mathrm{CF}_{2}\left(\mathrm{SO}_{2} \mathrm{OLi}\right)_{2}
$$

A $7.78 \mathrm{~g}\left(0.0224\right.$ moles) sample of $\mathrm{Ba}\left(\mathrm{OSO}_{2}\right)_{2} \mathrm{CF}_{2}$ (3M: L5428 ) was digested with $2.85 \mathrm{~g}$ (0.0223 moles) $\mathrm{Li}_{2} \mathrm{SO}_{4} \cdot \mathrm{H}_{2} \mathrm{O}$ (Mallinckrodt AR Grade) in $\sim 650 \mathrm{ml}$ of water. This mixture was warmed to $40^{\circ} \mathrm{C}$ for four days (to allow the $\mathrm{BaSO}_{4}$ time enough to form crystals large enough for filtration). The precipitate was filtered through a fritted disc filter (ASTM 10-15M) and washed. The remaining liquid was cloudy, so it was filtered again using whatman \#42 filter paper. The resulting clear solution was rotary evaporated to a small volume, then subjected to freeze drying on the vacuum line. Weight of product: $4.29 \mathrm{~g}$; yield: 85.58 . This sample started to turn gray at $224^{\circ} \mathrm{C}$.

$$
\text { SYNTHESIS OF }\left(\mathrm{CF}_{2} \mathrm{SO}_{2} \mathrm{OLi}\right)_{2}
$$

A $10.69 \mathrm{~g}$ sample $(0.03160 \mathrm{~mole})$ of $\left(\mathrm{KOSO}_{2} \mathrm{CF}_{2}\right)_{2}(3 \mathrm{M}: \mathrm{L}-$ 5433) was passed over two columns of acid form Amberlite IR120 (140 ml) to assure quantitative conversion; total residence time was about $2 \mathrm{hr}$. Rinsing with three bed volumes of water $(400 \mathrm{ml})$ took over an hour. The total volume of solution and washings was $550 \mathrm{ml}$, but this was decreased to around $200 \mathrm{ml}$ using a hot plate. Addition of too much LiOH $\cdot \mathrm{H}_{2} \mathrm{O}$ (MCB: ACS Grade) accidentally raised the $\mathrm{pH}$ to 9.6 , so $0.62 \mathrm{~g}(0.0018$ mole) more salt was converted 
to the acid form to decrease the $\mathrm{pH}$. The addition of the solution and washings brought the $\mathrm{pH}$ down to 6.4 ; the total solution volume was then decreased on hot plate. The solution was at first frozen and dried in a $25 \mathrm{ml}$ round bottomed flask, but this developed a star crack. The contents were transferred to a $50 \mathrm{ml}$ round bottomed flask and drying was completed. The yield was $8.47 \mathrm{~g}$, or $92.5 \%$.

A sample of previously prepared lithium salt turned brown at $269^{\circ} \mathrm{C}$.

$$
\text { SYNTHESIS OF } \mathrm{CF}_{2}\left(\mathrm{CF}_{2} \mathrm{SO}_{2} \mathrm{OLi}\right)_{2}
$$

A $4.10 \mathrm{~g}(0.0106$ moles $)$ portion of $\mathrm{CF}_{2}\left(\mathrm{CF}_{2} \mathrm{SO}_{2} \mathrm{OK}\right)_{2}$ (3M) was dissolved in $\sim 60 \mathrm{ml}$ of water and sent through about 70 ml of Amerlite IR-120 in the acid form, then washed with portions of water. Residence and rinsing times together amounted to over an hour. A $0.92 \mathrm{~g}$ sample of $\mathrm{LiOH} \cdot \mathrm{H}_{2} \mathrm{O}$ (MCB: ACS Grade) was added to neutralize most of the acid present, then brought to $\mathrm{pH} 8.1$ using small portions of hydroxide solution. The solution obtained was rotary evaporated down to less than $25 \mathrm{ml}$, then freeze dried on the vacuum line. The white powder weighted $3.41 \mathrm{~g}$, representing a 99.68 yield. The powder turns gray at $295^{\circ} \mathrm{C}$.

$$
\text { SYNTHESIS OF }\left(\mathrm{CF}_{2} \mathrm{CF}_{2} \mathrm{SO}_{2} \mathrm{OLi}\right)_{2}
$$

A $5.03 \mathrm{~g}$ portion of $\mathrm{Ca}\left(\mathrm{OSO}_{2} \mathrm{CF}_{2} \mathrm{CF}_{2}\right)_{2}$ (0.0126 moles) (3M: L-9123) was converted into acid form by dissolving in $\sim 60 \mathrm{ml}$ 
of water and dripping the resulting solution over $-70 \mathrm{ml}$ of Amberlite IR-120 in the acid form. Residence and washing time taken together were over an hour. Miscalculation of the required weight of $\mathrm{LiOH} \cdot \mathrm{H}_{2} \mathrm{O}$ (MCB: Reagent Grade) required made the $1.09 \mathrm{~g}$ that was added an excess; solution $\mathrm{pH}$ became 9.9. So $0.50 \mathrm{~g}$ more calcium salt was turned into the acid form, and the resulting solution was added to the basic mixture. The $\mathrm{pH} 3.2$ solution was then neutralized to $\mathrm{pH} 7.0$ with more $\mathrm{LiOH} \cdot \mathrm{H}_{2} \mathrm{O}$, and reduced in volume to less than $25 \mathrm{ml}$. Freeze drying on the vacuum line gave $4.83 \mathrm{~g}$ of product; yield: 93.58 . A portion of the white powder turned dark when heated to $312^{\circ} \mathrm{C}$.

$$
\text { SYNTHESIS OF O }\left(\mathrm{CF}_{2} \mathrm{CF}_{2} \mathrm{SO}_{2} \mathrm{OLi}\right)_{2}
$$

A $5.00 \mathrm{~g}$ portion $\left(0.0120\right.$ moles) of $\mathrm{Ca}\left(\mathrm{OSO}_{2} \mathrm{CF}_{2} \mathrm{CF}_{2}\right)_{2} \mathrm{O}$ (3M: L-9511) was dissolved in $-20 \mathrm{ml}$ of water and passed through -70 $\mathrm{ml}$ of Amberlite IR-120 over a period exceeding an hour. The column was washed with three bed volumes of water $(200$ ml). $\mathrm{MCB}$ Reagent Grade $\mathrm{LiOH} \cdot \mathrm{H}_{2} \mathrm{O}$ was added to the resulting solution until the $\mathrm{pH}$ reached 7.0 . The solution of the lithium salt was slowly concentrated by evaporation at $40^{\circ} \mathrm{C}$, then freeze-dried on the vacuum line to a fluffy white powder. Yield: $>2.84 \mathrm{~g} ;>60.8 \%$.

\section{POLYMER SALT SYNTHESIS}

A sample of the polymer of 


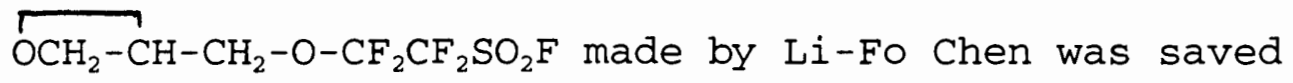
with the phosphoric acid used for polymerization. A $10 \mathrm{ml}$ solution of the polymer in chloroform was prepared, then washed with seven $10 \mathrm{ml}$ portions of water to dissolve away the acid. The washing was continued until there was no further rise in $\mathrm{pH}$; the $\mathrm{pH}$ of the washwater was found to be 4-5 by pH paper. The chloroform solution was then centrifuged to break the chloroform-water emulsion that had formed. The chloroform solution was then transferred to a weighed $50 \mathrm{ml}$ round-bottomed flask along with the three chloroform washings used to rinse the centrifuge tube. The chloroform was drawn off under vacuum; yield of polymer: $0.4519 \mathrm{~g}$ ( $1.764 \times 10^{-3}$ moles $)$.

A $27.0 \mathrm{ml}$ portion of $0.1225 \mathrm{M} \mathrm{LiOH}\left(3.31 \times 10^{-3}\right.$ moles), calculated to keep the polymer in slight excess, was added. The light brown polymer reacted slowly upon stirring to give a cloudy solution. After stirring, at room temperature for a month, the $\mathrm{pH}$ was found to be 8.0. An IR spectrum of the solution showed no $\mathrm{S}-\mathrm{F}$ stretch at $755-815 \mathrm{~cm}^{-1}$. The mixture was filtered through a $0.22 \mu \mathrm{m}$ membrane filter, but was still cloudy. The filtrate was then treated with $\sim 2 \mathrm{~g}$ Norit A decolorizing carbon, and filtered. The solution was then passed through a $0.2 \mu \mathrm{m}$ membrane filter. The solution volume was reduced to $25 \mathrm{ml}$; it was placed in a $50 \mathrm{ml}$ round bottomed flask, and freeze dried on the vacuum line. After the stirring bar had become stuck in the polymer, the whole 
flask was placed in a wide mouthed jar with $\mathrm{P}_{4} \mathrm{O}_{10}$ for ten days. The weight of polymer was $0.2245 \mathrm{~g}$, representing a $52.13 \%$ yield. The polymer salt was found to turn brown at $223^{\circ} \mathrm{C}$.

The above lithium compounds have been characterized by elemental analysis (Table II) mass spectrometry (Tables IIIXVIII), infrared spectroscopy (Tables XIX-XXVII), and ${ }^{1} \mathrm{H},{ }^{19} \mathrm{~F}$ and ${ }^{13} \mathrm{C}$ nuclear magnetic resonance spectroscopy (Tables XXVIII-XXXII) . 
TABLE II

ELEMENTAL ANALYSES

\begin{tabular}{|c|c|c|}
\hline & Calc. & Found \\
\hline \multicolumn{3}{|c|}{$\mathrm{SF}_{5} \mathrm{CH}_{2} \mathrm{CH}_{2} \mathrm{SO}_{3} \mathrm{Li}$} \\
\hline$\% \mathrm{C}$ & 9.92 & 9.77 \\
\hline$\% \mathrm{H}$ & 1.67 & 1.76 \\
\hline$\% F$ & $38 . .8$ & 38.8 \\
\hline$\% \mathrm{~S}$ & 26.5 & 26.48 \\
\hline \multicolumn{3}{|c|}{$\mathrm{SF}_{5} \mathrm{CH}_{2} \mathrm{CF}_{2} \mathrm{SO}_{3} \mathrm{Li}$} \\
\hline$\% \mathrm{C}$ & 8.64 & 8.79 \\
\hline$\% \mathrm{H}$ & 0.72 & 0.98 \\
\hline$\% F$ & 47.8 & 46.4 \\
\hline$\% S$ & 23.06 & 22.36 \\
\hline \multicolumn{3}{|c|}{$\mathrm{SF}_{5} \mathrm{CHFCF}_{2} \mathrm{SO}_{3} \mathrm{Li}$} \\
\hline$\% \mathrm{C}$ & 8.11 & 8.03 \\
\hline$\% \mathrm{H}$ & 0.34 & 0.41 \\
\hline$\% F$ & 51.3 & 50.9 \\
\hline \multicolumn{3}{|c|}{$\mathrm{CF}_{2}\left(\mathrm{SO}_{3} \mathrm{Li}\right)_{2} \cdot 3 / 2 \mathrm{H}_{2} \mathrm{O}$} \\
\hline$\% \mathrm{C}$ & 4.78 & 5.71 \\
\hline$\% \mathrm{H}$ & 1.20 & 1.39 \\
\hline$\% \mathrm{~F}$ & 15.1 & 15.2 \\
\hline \multicolumn{3}{|c|}{$\left(\mathrm{CF}_{2} \mathrm{SO}_{3} \mathrm{Li}\right)_{2} \cdot 2 \mathrm{H}_{2} \mathrm{O}$} \\
\hline$\% \mathrm{C}$ & 7.75 & 8.36 \\
\hline$\% \mathrm{H}$ & 1.30 & 1.39 \\
\hline$\% F$ & 24.5 & 24.2 \\
\hline \multicolumn{3}{|c|}{$\mathrm{CF}_{2}\left(\mathrm{CF}_{2} \mathrm{SO}_{3} \mathrm{Li}\right)_{2} \cdot 2 \mathrm{H}_{2} \mathrm{O}$} \\
\hline$\% \mathrm{C}$ & 10.01 & 9.74 \\
\hline$\% H$ & 1.12 & 0.99 \\
\hline
\end{tabular}




\begin{tabular}{||c|c|c||}
\hline$\% \mathrm{~F}$ & 31.7 & 30.1 \\
\hline \hline$\left(\mathrm{CF}_{2} \mathrm{CF}_{2} \mathrm{SO}_{3} \mathrm{Li}\right)_{2} \cdot 3 / 2 \mathrm{H}_{2} \mathrm{O}$ & & \\
\hline$\% \mathrm{C}$ & 11.98 & 12.37 \\
\hline$\% \mathrm{H}$ & 0.75 & 0.84 \\
\hline$\% \mathrm{~F}$ & 37.9 & 37.7 \\
\hline
\end{tabular}

MASS SPECTRA

Fast atom bombardment mass spectroscopy ${ }^{101-103}$ was performed on both pentafluorothio alkyl and perfluoroalkyl sulfonic acid lithium salts in a glycerin matrix. The fast atom bombardment technique has been used before to advantage in the characterization of perfluoroalkyl sulfonates. ${ }^{104}$ Runs producing both positive and negative ions were made. For the positive ions, every salt tested gave a base peak of $\mathrm{M} / \mathrm{e}=99$. At first this peak was assigned solely to $\mathrm{CSO}_{3} \mathrm{Li}^{+}$since Robert $\mathrm{J}$. Willenbring assigned base peaks with $\mathrm{M} / \mathrm{e}=115$ for his $\mathrm{SF}_{5}$ sulfonic acid sodium salts to the $\mathrm{CSO}_{3} \mathrm{Na}^{+}$ion. ${ }^{88}$ But this assignment was brought into question ${ }^{105}$ because these 100.00 relative intensity peaks did not have corresponding ${ }^{34} \mathrm{~S}$ isotopic peaks for $\mathrm{M} / \mathrm{e}=101$ at relative intensity 4.4. No reasonable carbon, fluorine and hydrogen combinations can give $\mathrm{M} / \mathrm{e}=99$; other possibilities were examined.

These spectra were run in glycerin, and glycerin peaks have been reported in FAB mass spectra where glycerin was used as the matrix. ${ }^{88,106,107}$ It is likely that the $\mathrm{M} / \mathrm{e}=99$ 
peak found in the positive ion mode spectra might more appropriately be attributed to a glycerin molecule (mass 92) ionized with a lithium ion (mass 7 ) as well as to some $\mathrm{CSO}_{3} \mathrm{Li}^{+}$. The propensity of polar organic molecules for taking up lithium ions has been used as a method for surface ionization. ${ }^{108}$ This would explain willenbring's base peaks with $\mathrm{M} / \mathrm{e}=115\left(\mathrm{C}_{3} \mathrm{H}_{8} \mathrm{O}_{3} \cdot \mathrm{Na}\right)^{+}$and their similar lack of corresponding ${ }^{34} \mathrm{~S}$ isotope peaks having relative intensity 4.4. Other positive ions that may be assigned to glycerin fragments are $\mathrm{M} / \mathrm{e}=57\left(\mathrm{C}_{3} \mathrm{H}_{5} \mathrm{O}\right)^{+}, \mathrm{M} / \mathrm{e}=59\left(\mathrm{C}_{3} \mathrm{H}_{7} \mathrm{O}\right)^{+}$, and $\mathrm{M} / \mathrm{e}=$ $73\left(\mathrm{C}_{3} \mathrm{H}_{5} \mathrm{O}_{2}\right)^{+}$.

These simple glycerin ions are not the only ions due to the matrix that are present, since glycerin also forms cluster ions. In one FAB study performed on neat glycerin, ions like $\left(\mathrm{C}_{3} \mathrm{H}_{8} \mathrm{O}_{3} \cdot \mathrm{H}\right)^{+},\left(\mathrm{C}_{3} \mathrm{H}_{8} \mathrm{O}_{3} \cdot 2 \mathrm{H}\right)^{+},\left(2 \mathrm{C}_{3} \mathrm{H}_{8} \mathrm{O}_{3}-\mathrm{H}\right)^{+},\left(2 \mathrm{C}_{3} \mathrm{H}_{8} \mathrm{O}_{3} \cdot \mathrm{H}\right)^{+}$, $\left(2 \mathrm{C}_{3} \mathrm{H}_{8} \mathrm{O}_{3} \cdot 2 \mathrm{H}\right)^{+},\left(3 \mathrm{C}_{3} \mathrm{H}_{8} \mathrm{O}_{3} \cdot \mathrm{H}\right)^{+},\left(3 \mathrm{C}_{3} \mathrm{H}_{8} \mathrm{O}_{3} \cdot 2 \mathrm{H}\right)^{+}$, etc. also appeared along with the simple glycerin fragments. ${ }^{107}$ In the lithium salt spectra, not only were combinations like $\left(\mathrm{C}_{3} \mathrm{H}_{8} \mathrm{O}_{3} \cdot \mathrm{H}\right)^{+}$ $(\mathrm{M} / \mathrm{e}=93),\left(\mathrm{C}_{3} \mathrm{H}_{8} \mathrm{O}_{3} \cdot 2 \mathrm{H}\right)^{+}(\mathrm{M} / \mathrm{e}=94)$ or $\left(2 \mathrm{C}_{3} \mathrm{H}_{8} \mathrm{O}_{3} \cdot 2 \mathrm{H}\right)^{+}(\mathrm{M} / \mathrm{e}=$ 186) found, but combinations containing lithium were noted: $\left(2 \mathrm{C}_{3} \mathrm{H}_{8} \mathrm{O}_{3} \cdot \mathrm{Li}\right)^{+}(\mathrm{M} / \mathrm{e}=191)$ and $\left(\mathrm{C}_{3} \mathrm{H}_{7} \mathrm{O}_{3} \cdot 2 \mathrm{Li}\right)^{+}(\mathrm{M} / \mathrm{e}=105)$. Hybrid ions turned up, too: in the $\mathrm{SF}_{5} \mathrm{CH}_{2} \mathrm{CH}_{2} \mathrm{SO}_{2} \mathrm{Li}$ positive mode spectrum, $\left(\mathrm{M} \cdot \mathrm{C}_{3} \mathrm{H}_{8} \mathrm{O}_{3} \cdot \mathrm{Li}\right)^{+}(\mathrm{M} / \mathrm{e}=341)$ and $\left(2 \mathrm{M} \cdot \mathrm{C}_{3} \mathrm{H}_{8} \mathrm{O}_{3} \cdot \mathrm{Li}\right)^{+}$ $(M / e=583)$ were found to be present. These hybrids should not seem strange in a spectrum where $\left(\mathrm{C}_{3} \mathrm{H}_{8} \mathrm{O}_{3} \cdot \mathrm{Li}\right)^{+}$is the base peak. Perhaps there are glycerin-glycerin fragment peaks as 
well; the $\mathrm{CF}_{2}\left(\mathrm{CF}_{2} \mathrm{SO}_{2} \mathrm{OLi}\right)_{2}$ negative ion mode $\left(2 \mathrm{C}_{3} \mathrm{H}_{8} \mathrm{O}_{3} \cdot \mathrm{C}_{2} \mathrm{H}_{3} \mathrm{O}\right)^{-}$ $(M / e=227)$ is an instance. Since these do not seem to appear in the FAB study of pure glycerin cited above, their existence seems questionable.

No molecular ions were seen among the positive ions. Remarkably neither the $\mathrm{SF}_{3}{ }^{+}$base peak, nor any of the other sulfur-fluorine ions $\left(\mathrm{SF}_{5}{ }^{+}, \mathrm{SF}_{4}{ }^{+}, \mathrm{SF}_{2}{ }^{+}, \mathrm{SF}^{+}\right)$reported by Willenbring ${ }^{88}$ appeared.

The negative ions did not include molecular ion peaks either. The negative ions showed more individuality as to base peak: only two salts gave the same M/e value for the base peak.

Cluster ions were noted for the salts in both positive and negative ion mode, but they were more common for the negative ions. Cluster ions of high mass have been reported for perfluoralkyl sulfonic acid salts; ${ }^{104,109}$ Willenbring reported them also for pentafluorothio alkyl sulfonic acids and salts. ${ }^{88}$ Most of the samples, accordingly, have peaks with M/e values higher than the molecular weights. Cluster ions resulting from the gain or loss of lithium ions are especially noteworthy: there are several salts with M-Li base peaks and one with an (M. Li)- base peak in negative ion mode. For difluoromethane disulfonic acid dilithium salt, negative ion mode gave: (M-Li)- (relative intensity 44.90), $(2 \mathrm{M}-\mathrm{Li})^{-}$(relative intensity 21.64), (2M-Li)- (18.66), $(2 \mathrm{M} \cdot 3 \mathrm{Li})^{-}(10.62),(3 \mathrm{M}-\mathrm{Li})^{-}(1.98),(3 \mathrm{M} \cdot \mathrm{Li})^{-}(1.38)$. 
These cluster ions with lithium were not the only kind found. Ions of the form $(\mathrm{M} \cdot \mathrm{F})^{-}$or $\left(\mathrm{M} \cdot \mathrm{SO}_{3}\right)^{-} \operatorname{turn} \mathrm{up}$, and the larger cluster ions $(2 \mathrm{M} \cdot \mathrm{F})^{-},(3 \mathrm{M} \cdot \mathrm{F})^{-},\left(2 \mathrm{M} \cdot \mathrm{SO}_{3}\right)^{-},\left(3 \mathrm{M} \cdot \mathrm{SO}_{3}\right)^{-}$, are seen as well. Each of these appeared in the negative spectrum for $\mathrm{SF}_{5} \mathrm{CH}_{2} \mathrm{CH}_{2} \mathrm{SO}_{2} \mathrm{OLi}$. More involved examples are seen in the $\left(\mathrm{M} \cdot \mathrm{CF}_{2} \mathrm{CF}_{2} \mathrm{CF}_{2} \mathrm{SO}_{3} \mathrm{H}\right)^{-}$of $\mathrm{CF}_{2}\left(\mathrm{CF}_{2} \mathrm{SO}_{3} \mathrm{Li}\right)_{2}$, or the $\left(\mathrm{M} \cdot \mathrm{SF}_{5} \mathrm{C}_{2} \mathrm{HFSO}\right)_{3}^{-}$of $\mathrm{SF}_{5} \mathrm{CH}_{2} \mathrm{CF}_{2} \mathrm{SO}_{2} \mathrm{OLi}$.

Lithium isotopic peaks due to ${ }^{6} \mathrm{Li}$ were found in the mass spectra as well as sulfur isotopic peaks. Natural lithium is $7.58{ }^{6} \mathrm{Li}$ and $92.58{ }^{7} \mathrm{Li}$, so a peak with $\mathrm{M} / \mathrm{e}=\mathrm{N}$ should have a companion peak at $\mathrm{M} / \mathrm{e}=\mathrm{N}-1$ with $8.11 \%$ of its relative intensity. For the positive mode spectrum of $\mathrm{CF}_{2}\left(\mathrm{CF}_{2} \mathrm{SO}_{2} \mathrm{OLi}\right)_{2}$, the $\mathrm{M} / \mathrm{e}=99.2$ assigned to $\mathrm{C}_{3} \mathrm{H}_{8} \mathrm{O}_{3} \cdot \mathrm{Li}$ (relative intensity 100.00) has a companion at 98.2 (relative intensity 8.63), and the $\mathrm{M} / \mathrm{e}=105.2$ assigned to $\mathrm{C}_{3} \mathrm{H}_{8} \mathrm{O}_{3} \cdot 2 \mathrm{Li}$ (relative intensity 37.08 ) has a companion at 104.2 (relative intensity 5.96).

Consequently an interesting phenomenon can be observed for ions containing both lithium and sulfur: a run of four peaks is generated due to the presence of four isotope combinations - a $\left({ }^{6} \mathrm{Li},{ }^{32} \mathrm{~S}\right)$, a $\left({ }^{7} \mathrm{Li},{ }^{32} \mathrm{~S}\right)$, a $\left({ }^{6} \mathrm{Li},{ }^{34} \mathrm{~S}\right)$ and a $\left({ }^{7} \mathrm{Li},{ }^{34} \mathrm{~S}\right)$ peak. Relative abundance ratios would se the relative peak heights for these four at $0.081,1.000$, 0.0036 , and 0.044 respectively, assuming one lithium and one sulfur in the molecule. An example of such a run of four is furnished by $\left(\mathrm{CF}_{2} \mathrm{SO}_{2} \mathrm{OLi}\right)_{2}$ in negative ion mode: there are 
four peaks for $\mathrm{M}-\mathrm{Li}$ at $\mathrm{M} / \mathrm{e}=266-269$.

The assigned peaks for both of the kinds of salts analyzed were consistent with the structures assigned to them.

\section{TABLE III}

$\mathrm{SF}_{5} \mathrm{CH}_{2} \mathrm{CH}_{2} \mathrm{SO}_{2} \mathrm{OLi} \quad$ M.W. 242

\begin{tabular}{|c|c|c|}
\hline Positive & & \\
\hline Mass & Rel. Int. & Type \\
\hline 31.1 & 3.02 & $\mathrm{CF}^{+}$ \\
\hline 33.1 & 5.26 & $\mathrm{CH}_{2} \mathrm{~F}^{+}$ \\
\hline 45.1 & 2.65 & \\
\hline 57.1 & 2.78 & $\mathrm{C}_{3} \mathrm{H}_{5} \mathrm{O}^{+}$ \\
\hline 93.1 & 2.60 & $\left(\mathrm{C}_{3} \mathrm{H}_{8} \mathrm{O}_{3} \cdot \mathrm{H}\right)^{+}$ \\
\hline 98.1 & 9.03 & $\left(\mathrm{C}_{3} \mathrm{H}_{8} \mathrm{O}_{3} \cdot \mathrm{Li}\right)^{+}\left({ }^{6} \mathrm{Li}\right) ; \mathrm{CF}_{2} \mathrm{SO}^{+}$ \\
\hline 99.1 & 100.00 & $\left(\mathrm{C}_{3} \mathrm{H}_{8} \mathrm{O}_{3} \cdot \mathrm{Li}\right)^{+}\left({ }^{7} \mathrm{Li}\right), \mathrm{CSO}_{3} \mathrm{Li}^{+}$ \\
\hline 100.1 & 3.32 & \\
\hline 104.2 & 2.44 & $\left(\mathrm{C}_{3} \mathrm{H}_{7} \mathrm{O}_{3} \cdot 2 \mathrm{Li}\right)^{+}\left({ }^{6} \mathrm{Li}\right)$ \\
\hline 105.2 & 14.43 & $\left(\mathrm{C}_{3} \mathrm{H}_{7} \mathrm{O}_{3} \cdot 2 \mathrm{Li}\right)^{+}\left({ }^{7} \mathrm{Li}\right)$ \\
\hline 155.2 & 7.76 & $\mathrm{SF}_{5} \mathrm{CH}_{2} \mathrm{CH}_{2}^{+}$ \\
\hline 191.2 & 7.02 & $\left(2 \mathrm{C}_{3} \mathrm{H}_{8} \mathrm{O}_{3} \cdot \mathrm{Li}\right)^{+}$ \\
\hline 201.3 & 5.60 & $\mathrm{SF}_{5} \mathrm{CHCHSO}^{+}$ \\
\hline 249.1 & 3.38 & $(\mathrm{M} \cdot \mathrm{Li})^{+}$ \\
\hline 341.2 & 4.91 & $\left(\mathrm{M} \cdot \mathrm{C}_{3} \mathrm{H}_{8} \mathrm{O}_{3} \cdot \mathrm{Li}\right)^{+}$ \\
\hline 433.3 & 2.75 & \\
\hline 491.2 & 2.41 & $\left(2 \mathrm{M} \cdot \mathrm{Li}^{+}\right)^{+}$ \\
\hline 583.2 & 1.50 & $\left(2 \mathrm{M} \cdot \mathrm{C}_{3} \mathrm{H}_{8} \mathrm{O}_{3} \cdot \mathrm{Li}\right)^{+}$ \\
\hline 733.2 & 1.15 & $(3 \mathrm{M} \cdot \mathrm{Li})^{+}$ \\
\hline
\end{tabular}


TABLE IV

$\mathrm{SF}_{5} \mathrm{CH}_{2} \mathrm{CH}_{2} \mathrm{SO}_{2} \mathrm{OLI} \quad$ M.W. 242

\begin{tabular}{|c|c|c|}
\hline \multicolumn{2}{|c|}{ Negative } & \multirow[b]{2}{*}{ Type } \\
\hline Mass & Rel. Int. & \\
\hline 19.1 & 2.65 & $F^{-}$ \\
\hline 80.1 & 6.18 & $\mathrm{SO}_{3}^{-}$ \\
\hline 91.2 & 3.43 & $\mathrm{C}_{3} \mathrm{H}_{7} \mathrm{O}_{3}^{-}$ \\
\hline 99.1 & 8.22 & $\mathrm{SO}_{3} \mathrm{~F}$ \\
\hline 106.1 & 8.08 & $\mathrm{C}_{2} \mathrm{H}_{2} \mathrm{SO}_{3}^{-}$ \\
\hline 107.1 & 5.50 & $\mathrm{C}_{2} \mathrm{H}_{3} \mathrm{SO}_{3}^{-}$ \\
\hline 127.1 & 100.00 & $\left.\mathrm{SF}_{5} \cdot{ }^{32} \mathrm{~S}\right)$ \\
\hline 129.1 & 4.31 & $\mathrm{SF}_{5} \cdot\left({ }^{34} \mathrm{~S}\right)$ \\
\hline 133.2 & 2.29 & \\
\hline 153.2 & 3.74 & $\mathrm{SF}_{5} \mathrm{C}_{2} \mathrm{H}_{2}$ \\
\hline 235.2 & 77.17 & $\mathrm{SF}_{5} \mathrm{CH}_{2} \mathrm{CH}_{2} \mathrm{SO}_{3} \cdot\left({ }^{32} \mathrm{~S}\right)$ \\
\hline 236.2 & 2.24 & \\
\hline 237.2 & 6.25 & $\left.\mathrm{SF}_{5} \mathrm{CH}_{2} \mathrm{CH}_{2} \mathrm{SO}_{3} \cdot{ }^{34} \mathrm{~S}\right)$ \\
\hline 260.2 & 3.12 & $(M \cdot F)^{-}\left({ }^{6} \mathrm{Li},{ }^{32} \mathrm{~S}\right)$ \\
\hline 261.2 & 44.09 & $(M \cdot F)^{-}\left({ }^{7} L i,{ }^{32} S\right)$ \\
\hline 263.2 & 3.36 & $(M \cdot F) \cdot\left({ }^{7} \mathrm{Li},{ }^{34} \mathrm{~S}\right)$ \\
\hline 322.2 & 18.48 & $\left(\mathrm{M} \mathrm{SO}_{3}\right) \cdot\left({ }^{32} \mathrm{~S}\right)$ \\
\hline 324.2 & 2.00 & $\left(\mathrm{M} \cdot \mathrm{SO}_{3}\right)^{-}\left({ }^{34} \mathrm{~S}\right)$ \\
\hline 333.3 & 3.09 & \\
\hline 348.2 & 3.53 & \\
\hline 349.2 & 2.65 & \\
\hline 476.3 & 7.30 & $(2 \mathrm{M}-\mathrm{Li}) \cdot\left({ }^{6} \mathrm{Li},{ }^{32} \mathrm{~S}\right)$ \\
\hline 477.3 & 94.29 & $(2 \mathrm{M}-\mathrm{Li})^{-}\left({ }^{7} \mathrm{Li},{ }^{32} \mathrm{~S}\right)$ \\
\hline 478.3 & 8.39 & $(2 \mathrm{M}-\mathrm{Li})^{-}\left({ }^{6} \mathrm{Li},{ }^{34} \mathrm{~S}\right)$ \\
\hline 479.3 & 18.44 & $(2 \mathrm{M}-\mathrm{Li})^{-}\left({ }^{7} \mathrm{Li},{ }^{34} \mathrm{~S}\right)$ \\
\hline
\end{tabular}




\begin{tabular}{|c|c|c|}
\hline Mass & Rel. Int. & Type \\
\hline 503.3 & 6.25 & $(2 M \cdot F)^{-}$ \\
\hline 564.3 & 3.33 & $\left(2 \mathrm{M} \cdot \mathrm{SO}_{3}\right)^{-}$ \\
\hline 718.4 & 2.14 & $(3 \mathrm{M}-\mathrm{Li})^{-}\left({ }^{6} \mathrm{Li},{ }^{32} \mathrm{~S}\right)$ \\
\hline 719.4 & 16.78 & $(3 \mathrm{M}-\mathrm{Li})^{\cdot}\left({ }^{7} \mathrm{Li},{ }^{32} \mathrm{~S}\right)$ \\
\hline 721.4 & 4.31 & $(3 \mathrm{M}-\mathrm{Li})^{-}\left({ }^{7} \mathrm{Li},{ }^{34} \mathrm{~S}\right)$ \\
\hline 745.4 & 3.70 & $(3 \mathrm{M} \cdot \mathrm{F})^{-}$ \\
\hline 806.5 & 1.10 & $\left(3 \mathrm{M} \cdot \mathrm{SO}_{3}\right)^{-}$ \\
\hline 963.6 & 1.63 & \\
\hline
\end{tabular}

TABLE V

$\mathrm{SF}_{5} \mathrm{CH}_{2} \mathrm{CF}_{2} \mathrm{SO}_{2} \mathrm{OLi} \quad$ M.W. 278

\begin{tabular}{|c|c|c|}
\hline Positive & & \\
\hline Mass & Rel. Int. & Type \\
\hline 31.1 & 2.24 & $\mathrm{CF}^{+}$ \\
\hline 33.1 & 4.08 & $\mathrm{CH}_{2} \mathrm{~F}^{+}$ \\
\hline 98.1 & 8.96 & $\left(\mathrm{C}_{3} \mathrm{H}_{8} \mathrm{O}_{3} \cdot \mathrm{Li}\right)^{+}\left({ }^{6} \mathrm{Li}\right) ; \mathrm{CF}_{2} \mathrm{SO}^{+}$ \\
\hline 99.1 & 100.00 & $\left(\mathrm{C}_{3} \mathrm{H}_{8} \mathrm{O}_{3} \cdot \mathrm{Li}\right)^{+}\left({ }^{7} \mathrm{Li}\right), \mathrm{CSO}_{3} \mathrm{Li}^{+}$ \\
\hline 100.1 & 3.38 & $\mathrm{CF}_{2} \mathrm{CF}_{2}^{+}$ \\
\hline 104.2 & 3.02 & $\left(\mathrm{C}_{3} \mathrm{H}_{7} \mathrm{O}_{3} \cdot 2 \mathrm{Li}\right)^{+}\left({ }^{6} \mathrm{Li}\right)$ \\
\hline 105.2 & 18.57 & $\left(\mathrm{C}_{3} \mathrm{H}_{7} \mathrm{O}_{3} \cdot 2 \mathrm{Li}\right)^{+}\left({ }^{7} \mathrm{Li}\right)$ \\
\hline 125.2 & 2.14 & $\mathrm{CH}_{2} \mathrm{CFSO}_{3}^{+}$ \\
\hline 155.2 & 12.64 & $\mathrm{CF}_{2} \mathrm{CF}_{2} \mathrm{SOLi}^{+}, \mathrm{SF}_{5} \mathrm{CH}_{2} \mathrm{CH}_{2}{ }_{2}$ \\
\hline 191.2 & 7.45 & $\mathrm{SF}_{5} \mathrm{CH}_{2} \mathrm{CF}_{2}^{+}$ \\
\hline 201.2 & 9.44 & $\mathrm{SF}_{5} \mathrm{C}_{2} \mathrm{H}_{2} \mathrm{SO}^{+}$ \\
\hline 285.2 & 2.26 & $(\mathrm{M} \cdot \mathrm{Li})^{+}$ \\
\hline 377.2 & 1.02 & $\left(\mathrm{M} \cdot \mathrm{C}_{3} \mathrm{H}_{8} \mathrm{O}_{3} \cdot \mathrm{Li}\right)^{+}$ \\
\hline 469.2 & 1.03 & $\left(\mathrm{M} \cdot \mathrm{SO}_{3} \mathrm{Li}\right)^{+}$ \\
\hline
\end{tabular}


TABLE VI

$\mathrm{SF}_{5} \mathrm{CH}_{2} \mathrm{CF}_{2} \mathrm{SO}_{2} \mathrm{OLi} \quad$ M.W. 278

\begin{tabular}{|c|c|c|}
\hline \multicolumn{2}{|c|}{ Negative } & \multirow[b]{2}{*}{ Type } \\
\hline Mass & Rel. Int. & \\
\hline 19.1 & 3.07 & $F^{-}$ \\
\hline 80.1 & 3.11 & $\mathrm{SO}_{3} ; \mathrm{C}_{2} \mathrm{~F}_{2} \cdot \mathrm{H}_{2} \mathrm{O}$ \\
\hline 99.1 & 2.63 & $\mathrm{SO}_{3} \mathrm{~F}^{\prime}, \mathrm{CHF}_{2} \mathrm{SO}^{-}$ \\
\hline 106.1 & 3.07 & $\mathrm{C}_{2} \mathrm{H}_{2} \mathrm{SO}_{3}^{-}$ \\
\hline 125.1 & 2.30 & $\mathrm{C}_{2} \mathrm{H}_{2} \mathrm{FSO}_{3}^{-}$ \\
\hline 127.1 & 84.06 & $\mathrm{SF}_{5} \cdot\left({ }^{32} \mathrm{~S}\right)$ \\
\hline 129.1 & 3.00 & $\mathrm{SF}_{5} \cdot\left({ }^{34} \mathrm{~S}\right)$ \\
\hline 163.2 & 4.68 & \\
\hline 251.2 & 57.31 & $\mathrm{SF}_{5} \mathrm{C}_{2} \mathrm{HFSO}_{3}-\left({ }^{32} \mathrm{~S}\right)$ \\
\hline 253.2 & 4.17 & $\mathrm{SF}_{5} \mathrm{C}_{2} \mathrm{HFSO}_{3} \cdot\left({ }^{34} \mathrm{~S}\right)$ \\
\hline 271.1 & 100.00 & $\left.\mathrm{SF}_{5} \mathrm{CH}_{2} \mathrm{CF}_{2} \mathrm{SO}_{3} \cdot{ }^{32} \mathrm{~S}\right)$ \\
\hline 272.2 & 3.07 & \\
\hline 273.2 & 8.19 & $\mathrm{SF}_{5} \mathrm{CH}_{2} \mathrm{CF}_{2} \mathrm{SO}_{3} \cdot\left({ }^{34} \mathrm{~S}\right)$ \\
\hline 277.2 & 6.25 & $\mathrm{SF}_{5} \mathrm{C}_{2} \mathrm{HF}_{2} \mathrm{SO}_{3} \mathrm{Li}^{-}$ \\
\hline 297.2 & 14.29 & $(M \cdot F)^{-}$ \\
\hline 358.2 & 9.32 & $\left(\mathrm{M} \cdot \mathrm{SO}_{3}\right)^{-}$ \\
\hline 509.3 & 5.41 & \\
\hline 528.3 & 2.81 & $\left(\mathrm{M} \cdot \mathrm{SF}_{5} \mathrm{C}_{2} \mathrm{HF}_{2} \mathrm{SO}_{3}\right)^{-}\left({ }^{6} \mathrm{Li},{ }^{32} \mathrm{~S}\right)$ \\
\hline 529.3 & 42.47 & $\left(\mathrm{M} \cdot \mathrm{SF}_{5} \mathrm{C}_{2} \mathrm{HF}_{2} \mathrm{SO}_{3}\right)^{-}\left({ }^{\prime} \mathrm{Li},{ }^{32} \mathrm{~S}\right)$ \\
\hline 530.3 & 3.69 & $\left(\mathrm{M} \cdot \mathrm{SF}_{5} \mathrm{C}_{2} \mathrm{HF}_{2} \mathrm{SO}_{3}\right)^{-}\left({ }^{6} \mathrm{Li},{ }^{34} \mathrm{~S}\right)$ \\
\hline 531.3 & 7.79 & $\left(\mathrm{M} \cdot \mathrm{SF}_{5} \mathrm{C}_{2} \mathrm{HF}_{2} \mathrm{SO}_{3}\right)^{-}\left({ }^{7} \mathrm{Li},{ }^{34} \mathrm{~S}\right)$ \\
\hline 548.3 & 5.63 & $(2 \mathrm{M}-\mathrm{Li})^{-}\left({ }^{6} \mathrm{Li},{ }^{32} \mathrm{~S}\right)$ \\
\hline 549.3 & 77.92 & $(2 \mathrm{M}-\mathrm{Li})^{-}\left({ }^{7} \mathrm{Li},{ }^{32} \mathrm{~S}\right)$ \\
\hline 550.3 & 6.73 & $(2 \mathrm{M}-\mathrm{Li})^{-}\left({ }^{6} \mathrm{Li},{ }^{34} \mathrm{~S}\right)$ \\
\hline 551.3 & 13.49 & $(2 \mathrm{M}-\mathrm{Li})^{-}\left({ }^{7} \mathrm{Li},{ }^{34} \mathrm{~S}\right)$ \\
\hline
\end{tabular}




\begin{tabular}{|l|l|l||}
\hline 575.3 & 2.30 & $(2 \mathrm{M} \cdot \mathrm{F})^{-}$ \\
\hline 807.5 & 2.70 & $\left(3 \mathrm{M}-\mathrm{LiF}^{-}\right.$ \\
\hline 827.4 & 3.69 & $\left(3 \mathrm{M}-\mathrm{Li}^{-}\right.$ \\
\hline 833.5 & 2.16 & \\
\hline 853.4 & 2.96 & $(3 \mathrm{M} \cdot \mathrm{F})^{-}$ \\
\hline
\end{tabular}

TABLE VII

$\mathrm{SF}_{5} \mathrm{CHFCF}_{2} \mathrm{SO}_{2} \mathrm{OLI} \quad$ M.W. 296

\begin{tabular}{|c|c|c|}
\hline Positive & & \\
\hline Mass & Rel. Int. & Type \\
\hline 31.1 & 4.96 & $\mathrm{CF}^{+}$ \\
\hline 33.1 & 4.59 & $\mathrm{CH}_{2} \mathrm{~F}^{+}$ \\
\hline 98.1 & 9.51 & $\left(\mathrm{C}_{3} \mathrm{H}_{8} \mathrm{O}_{3} \cdot \mathrm{Li}\right)^{+}\left({ }^{6} \mathrm{Li}\right)$ \\
\hline 99.1 & 100.00 & $\left(\mathrm{C}_{3} \mathrm{H}_{8} \mathrm{O}_{3} \cdot \mathrm{Li}\right)^{+}\left({ }^{7} \mathrm{Li}\right), \mathrm{CSO}_{3} \mathrm{Li}^{+}$ \\
\hline 100.1 & 3.40 & $\mathrm{CF}_{2} \mathrm{CF}_{2}^{+}$ \\
\hline 104.2 & 4.91 & $\left(\mathrm{C}_{3} \mathrm{H}_{7} \mathrm{O}_{3} \cdot 2 \mathrm{Li}\right)^{+}\left({ }^{6} \mathrm{Li}\right)$ \\
\hline 105.2 & 29.48 & $\left(\mathrm{C}_{3} \mathrm{H}_{7} \mathrm{O}_{3} \cdot 2 \mathrm{Li}\right)^{+}\left({ }^{(} \mathrm{Li}\right)$ \\
\hline 111.2 & 2.25 & $\mathrm{CFSO}_{3}^{+}$ \\
\hline 155.2 & 8.99 & $\mathrm{CF}_{2} \mathrm{CF}_{2} \mathrm{SOLi}^{+}$ \\
\hline 186.2 & 6.13 & $\left(2 \mathrm{C}_{3} \mathrm{H}_{8} \mathrm{O}_{3} \cdot 2 \mathrm{H}\right)^{+}$ \\
\hline 191.2 & 3.53 & $\left(2 \mathrm{C}_{3} \mathrm{H}_{8} \mathrm{O}_{3} \cdot \mathrm{Li}\right)^{+}\left({ }^{7} \mathrm{Li}\right)$ \\
\hline 201.2 & 5.95 & $\mathrm{SF}_{5} \mathrm{CHCHSO}^{+}$ \\
\hline 245.2 & 8.69 & $\left(2 \mathrm{C}_{3} \mathrm{H}_{8} \mathrm{O}_{3} \cdot \mathrm{C}_{2} \mathrm{H}_{5} \mathrm{O}\right)^{+}$ \\
\hline 278.3 & 0.92 & $\mathrm{SF}_{5} \mathrm{C}_{2} \mathrm{H}_{2} \mathrm{~F}_{2} \mathrm{SO}_{3} \mathrm{Li}^{+}$ \\
\hline 337.2 & 1.40 & \\
\hline 581.2 & 0.93 & \\
\hline 721.2 & 1.52 & $\left(2 \mathrm{M} \cdot \mathrm{C}_{2} \mathrm{~F}_{3} \mathrm{SO}\right)^{+}$ \\
\hline
\end{tabular}


TABLE VIII

$\mathrm{SF}_{5} \mathrm{CHFCF}_{2} \mathrm{SO}_{2} \mathrm{OLI} \quad$ M.W. 296

\begin{tabular}{|c|c|c|}
\hline Negative & & \\
\hline Mass & Rel. Int. & Type \\
\hline 81.1 & 4.62 & $\mathrm{HSO}_{3}^{-}$ \\
\hline 211.2 & 2.26 & \\
\hline 231.2 & 100.00 & $\left(\mathrm{SF}_{5} \mathrm{C}_{2} \mathrm{SO}_{3}\right)^{\cdot}\left({ }^{32} \mathrm{~S}\right)$ \\
\hline 232.2 & 3.81 & \\
\hline 233.2 & 4.42 & $\left(\mathrm{SF}_{5} \mathrm{C}_{2} \mathrm{SO}_{3}\right) \cdot\left({ }^{34} \mathrm{~S}\right)$ \\
\hline 318.2 & 3.71 & \\
\hline 468.3 & 4.81 & $\left(\mathrm{M} \cdot \mathrm{C}_{3} \mathrm{H}_{8} \mathrm{O}_{3} \cdot \mathrm{C}_{2} \mathrm{~F}_{3}\right) \cdot\left({ }^{6} \mathrm{Li},{ }^{32} \mathrm{~S}\right)$ \\
\hline 469.3 & 62.74 & $\left(\mathrm{M} \cdot \mathrm{C}_{3} \mathrm{H}_{8} \mathrm{O}_{3} \cdot \mathrm{C}_{2} \mathrm{~F}_{3}\right)^{-}\left({ }^{7} \mathrm{Li},{ }^{32} \mathrm{~S}\right)$ \\
\hline 470.3 & 5.46 & $\left(\mathrm{M} \cdot \mathrm{C}_{3} \mathrm{H}_{8} \mathrm{O}_{3} \cdot \mathrm{C}_{2} \mathrm{~F}_{3}\right) \cdot\left({ }^{6} \mathrm{Li},{ }^{34} \mathrm{~S}\right)$ \\
\hline 471.3 & 6.40 & $\left(\mathrm{M} \cdot \mathrm{C}_{3} \mathrm{H}_{8} \mathrm{O}_{3} \cdot \mathrm{C}_{2} \mathrm{~F}_{3}\right) \cdot\left({ }^{7} \mathrm{Li},{ }^{34} \mathrm{~S}\right)$ \\
\hline 707.4 & 2.04 & \\
\hline 733.4 & 2.44 & $\left(2 \mathrm{M} \cdot \mathrm{SF}_{5} \mathrm{CH}_{2}\right)^{-}$ \\
\hline 945.6 & 2.21 & $\left(3 \mathrm{M} \cdot \mathrm{C}_{3} \mathrm{H}_{5} \mathrm{O}\right)^{-}$ \\
\hline
\end{tabular}


TABLE IX

$\mathrm{CF}_{2}\left(\mathrm{SO}_{2} \mathrm{OLi}\right)_{2} \quad$ M.W. 224

\begin{tabular}{|c|c|c|}
\hline Positive & & \\
\hline Mass & Rel. Int. & Type \\
\hline 31.1 & 8.39 & $\mathrm{CF}^{+}$ \\
\hline 33.1 & 5.59 & $\mathrm{CH}_{2} \mathrm{~F}^{+}$ \\
\hline 57.1 & 2.32 & $\mathrm{C}_{3} \mathrm{H}_{5} \mathrm{O}^{+}$ \\
\hline 73.1 & 2.06 & $\mathrm{C}_{3} \mathrm{H}_{5} \mathrm{O}_{2}^{+}$ \\
\hline 98.1 & 8.66 & $\left(\mathrm{C}_{3} \mathrm{H}_{8} \mathrm{O}_{3} \cdot \mathrm{Li}\right)^{+}\left({ }^{6} \mathrm{Li}\right)$ \\
\hline 99.1 & 100.00 & $\left(\mathrm{C}_{3} \mathrm{H}_{8} \mathrm{O}_{3} \cdot \mathrm{Li}\right)^{+}\left({ }^{7} \mathrm{Li}\right), \mathrm{CSO}_{3} \mathrm{Li}^{+}$ \\
\hline 100.1 & 3.64 & $\mathrm{CF}_{2} \mathrm{CF}_{2}^{+}$ \\
\hline 101.1 & 2.10 & $\mathrm{CF}_{2} \mathrm{CF}_{2} \mathrm{H}^{+}$ \\
\hline 104.2 & 5.80 & $\left(\mathrm{C}_{3} \mathrm{H}_{7} \mathrm{O}_{3} \cdot 2 \mathrm{Li}\right)^{+}\left({ }^{6} \mathrm{Li}\right)$ \\
\hline 105.2 & 37.81 & $\left(\mathrm{C}_{3} \mathrm{H}_{7} \mathrm{O}_{3} \cdot 2 \mathrm{Li}\right)^{+}\left({ }^{\prime} \mathrm{Li}\right)$ \\
\hline 111.2 & 4.28 & $\mathrm{CFSO}_{3}{ }^{+}$ \\
\hline 155.2 & 7.42 & $\mathrm{CF}_{2} \mathrm{CF}_{2} \mathrm{SOLi}^{+}$ \\
\hline 191.2 & 1.61 & $\mathrm{CF}\left(\mathrm{SO}_{3}\right)_{2}^{+},\left(2 \mathrm{C}_{3} \mathrm{H}_{8} \mathrm{O}_{3} \cdot \mathrm{Li}\right)^{+}$ \\
\hline 201.2 & 2.59 & $\mathrm{SO}_{2} \mathrm{CF}_{2} \mathrm{SO}_{3} \mathrm{Li}^{+}$ \\
\hline 231.1 & 3.86 & $(\mathrm{M} \cdot \mathrm{Li})^{+}\left({ }^{7} \mathrm{Li},{ }^{32} \mathrm{~S}\right)$ \\
\hline 323.2 & 1.02 & $\left(\mathrm{M} \cdot \mathrm{C}_{3} \mathrm{H}_{8} \mathrm{O}_{3} \cdot \mathrm{Li}\right)^{+}$ \\
\hline 455.1 & 0.75 & $(2 \mathrm{M} \cdot \mathrm{Li})^{+}$ \\
\hline
\end{tabular}


TABLE X

$\mathrm{CF}_{2}\left(\mathrm{SO}_{2} \mathrm{OLI}\right)_{2} \quad$ M.W. 224

\begin{tabular}{|c|c|c|}
\hline \multicolumn{2}{|c|}{ Negative } & \multirow[b]{2}{*}{ Type } \\
\hline Mass & Rel. Int. & \\
\hline 80.1 & 9.45 & \\
\hline 81.1 & 7.93 & $\mathrm{HSO}_{3}^{\circ}$ \\
\hline 127.1 & 2.80 & \\
\hline 131.1 & 4.99 & \\
\hline 181.1 & 2.69 & \\
\hline 199.1 & 8.04 & $\mathrm{LiOSO}_{2} \mathrm{CFSO}_{2} \mathrm{OH}^{-}$ \\
\hline 211.1 & 11.30 & $\mathrm{HSO}_{3} \mathrm{CF}_{2} \mathrm{SO}_{3}^{-}$ \\
\hline 216.2 & 2.83 & $\mathrm{SO}_{3} \mathrm{CF}_{2} \mathrm{SO}_{3} \mathrm{Li}\left({ }^{6} \mathrm{Li},{ }^{32} \mathrm{~S}\right)$ \\
\hline 217.2 & 44.90 & $\mathrm{SO}_{3} \mathrm{CF}_{2} \mathrm{SO}_{3} \mathrm{Li}\left({ }^{7} \mathrm{Li},{ }^{32} \mathrm{~S}\right)$ \\
\hline 219.2 & 4.39 & $\mathrm{SO}_{3} \mathrm{CF}_{2} \mathrm{SO}_{3} \mathrm{Li}\left({ }^{7} \mathrm{Li},{ }^{34} \mathrm{~S}\right)$ \\
\hline 231.2 & 100.00 & $\left(\mathrm{CF}_{2}\left(\mathrm{SO}_{3} \mathrm{H}\right)_{2} \cdot \mathrm{F}\right)^{\left.-{ }^{32} \mathrm{~S}\right)}$ \\
\hline 232.2 & 3.29 & \\
\hline 223.2 & 4.57 & $\left(\mathrm{CF}_{2}\left(\mathrm{SO}_{3} \mathrm{H}\right)_{2} \cdot \mathrm{F}\right) \cdot\left({ }^{34} \mathrm{~S}\right)$ \\
\hline 243.2 & 3.82 & \\
\hline 269.2 & 2.66 & \\
\hline 299.2 & 10.52 & $\left(2 \mathrm{C}_{3} \mathrm{H}_{8} \mathrm{O}_{3} \cdot 2 \mathrm{C}_{3} \mathrm{H}_{5} \mathrm{O} \cdot \mathrm{H}\right)^{-}$ \\
\hline 304.2 & 3.68 & $\left(\mathrm{M} \cdot \mathrm{SO}_{3}\right)^{-}$ \\
\hline 311.2 & 3.05 & $\left(\mathrm{M} \cdot \mathrm{SO}_{3} \mathrm{Li}\right)^{-}$ \\
\hline 315.2 & 3.61 & \\
\hline 318.2 & 3.33 & \\
\hline 423.2 & 2.20 & $\left(\mathrm{MLiOSO}_{2} \mathrm{CFSO}_{2} \mathrm{OH}\right)^{-}$ \\
\hline 440.2 & 4.28 & $(2 \mathrm{M}-\mathrm{Li})^{-}\left({ }^{6} \mathrm{Li},{ }^{32} \mathrm{~S}\right)$ \\
\hline 441.2 & 21.64 & $(2 \mathrm{M}-\mathrm{Li})^{-}\left({ }^{7} \mathrm{Li},{ }^{32} \mathrm{~S}\right)$ \\
\hline 443.2 & 3.47 & $(2 \mathrm{M}-\mathrm{Li})^{-}\left({ }^{6} \mathrm{Li},{ }^{34} \mathrm{~S}\right)$ \\
\hline 454.3 & 2.90 & $(2 \mathrm{M} \cdot \mathrm{Li})^{-}\left({ }^{6} \mathrm{Li},{ }^{32} \mathrm{~S}\right)$ \\
\hline
\end{tabular}




\begin{tabular}{|c|c|l||}
\hline Mass & Rel. Int. & \multicolumn{1}{|c|}{ Type } \\
\hline 455.3 & 18.66 & $(2 \mathrm{M} \cdot \mathrm{Li})^{-}\left({ }^{7} \mathrm{Li},{ }^{32} \mathrm{~S}\right)$ \\
\hline 456.3 & 1.20 & $(2 \mathrm{M} \cdot \mathrm{Li})^{-}\left({ }^{6} \mathrm{Li}^{34} \mathrm{~S}\right)$ \\
\hline 457.3 & 2.76 & $(2 \mathrm{M} \cdot \mathrm{Li})^{-}\left({ }^{7} \mathrm{Li},{ }^{34} \mathrm{~S}\right)$ \\
\hline 469.3 & 10.62 & $(2 \mathrm{M} \cdot 3 \mathrm{Li})^{-}$ \\
\hline 537.3 & 1.20 & \\
\hline 665.3 & 1.98 & $(3 \mathrm{M}-\mathrm{Li})^{-}$ \\
\hline 679.4 & 1.38 & \\
\hline
\end{tabular}


TABLE XI

$\begin{array}{ll}\left(\mathrm{CF}_{2} \mathrm{SO}_{2} \mathrm{OLI}\right)_{2} & \text { M.W. } 274\end{array}$

\begin{tabular}{|c|c|c|}
\hline Positive & & \\
\hline Mass & Rel. Int. & Type \\
\hline 31.1 & 18.11 & $\mathrm{CF}^{+}$ \\
\hline 32.1 & 3.39 & $\mathrm{CHF}^{+}$ \\
\hline 33.1 & 29.08 & $\mathrm{CH}_{2} \mathrm{~F}^{+}$ \\
\hline 57.1 & 5.67 & $\mathrm{C}_{3} \mathrm{H}_{5} \mathrm{O}^{+}$ \\
\hline 59.1 & 7.57 & $\mathrm{C}_{3} \mathrm{H}_{7} \mathrm{O}^{+}$ \\
\hline 73.1 & 3.02 & $\mathrm{C}_{3} \mathrm{H}_{5} \mathrm{O}_{2}^{+}$ \\
\hline 94.1 & 4.77 & $\left(\mathrm{C}_{3} \mathrm{H}_{8} \mathrm{O}_{3} \cdot 2 \mathrm{H}\right)^{+}$ \\
\hline 98.1 & 7.42 & $\left(\mathrm{C}_{3} \mathrm{H}_{8} \mathrm{O}_{3} \cdot \mathrm{Li}\right)^{+}\left({ }^{6} \mathrm{Li}\right)$ \\
\hline 99.1 & 100.00 & $\left(\mathrm{C}_{3} \mathrm{H}_{8} \mathrm{O}_{3} \cdot \mathrm{Li}\right)^{+}\left({ }^{7} \mathrm{Li}\right), \mathrm{CSO}_{3} \mathrm{Li}^{+}$ \\
\hline 100.1 & 2.81 & $\mathrm{CF}_{2} \mathrm{CF}_{2}^{+}$ \\
\hline 101.1 & 3.71 & $\mathrm{CF}_{2} \mathrm{CF}_{2} \mathrm{H}^{+}$ \\
\hline 104.2 & 5.88 & $\left(\mathrm{C}_{3} \mathrm{H}_{7} \mathrm{O}_{3} \cdot 2 \mathrm{Li}\right)^{+}\left({ }^{6} \mathrm{Li}\right)$ \\
\hline 105.2 & 45.76 & $\left(\mathrm{C}_{3} \mathrm{H}_{7} \mathrm{O}_{3} \cdot 2 \mathrm{Li}\right)^{+}\left({ }^{7} \mathrm{Li}\right)$ \\
\hline 111.2 & 5.99 & $\mathrm{CFSO}_{3}^{+}$ \\
\hline 155.2 & 6.57 & $\mathrm{CF}_{2} \mathrm{CF}_{2} \mathrm{SOLi}^{+}$ \\
\hline 195.1 & 2.49 & \\
\hline 201.1 & 3.02 & \\
\hline 281.1 & 2.22 & $(\mathrm{M} \cdot \mathrm{Li})^{+}$ \\
\hline 381.1 & 0.90 & \\
\hline
\end{tabular}


TABLE XII

$\begin{array}{ll}\left(\mathrm{CF}_{2} \mathrm{SO}_{2} \mathrm{OLi}\right)_{2} & \text { M.W. } 274\end{array}$

\begin{tabular}{|c|c|c|}
\hline \multicolumn{2}{|c|}{ Negative } & \multirow[b]{2}{*}{ Type } \\
\hline Mass & Rel. Int. & \\
\hline 19.1 & 3.42 & $\mathrm{~F}^{\cdot}$ \\
\hline 80.1 & 32.06 & $\mathrm{SO}_{3}^{-}, \mathrm{C}_{2} \mathrm{~F}_{2} \cdot \mathrm{H}_{2} \mathrm{O}^{-}$ \\
\hline 81.2 & 3.62 & $\mathrm{HSO}_{3}^{-}$ \\
\hline 99.1 & 2.01 & \\
\hline 103.1 & 7.94 & \\
\hline 130.1 & 3.52 & $\left(\mathrm{C}_{3} \mathrm{H}_{4} \mathrm{O} \cdot \mathrm{C}_{3} \mathrm{H}_{6} \mathrm{O}_{2}\right)^{-}$ \\
\hline 131.1 & 2.01 & \\
\hline 143.1 & 2.61 & \\
\hline 161.2 & 36.08 & $\left.\mathrm{CF}_{2} \mathrm{CFSO}_{3} \cdot{ }^{(32} \mathrm{S}\right)$ \\
\hline 163.1 & 3.32 & $\mathrm{CF}_{2} \mathrm{CFSO}_{3} \cdot\left({ }^{34} \mathrm{~S}\right)$ \\
\hline 177.1 & 25.83 & $\mathrm{SCF}_{2} \mathrm{CFSO}_{2}^{-}$ \\
\hline 181.1 & 79.70 & $\mathrm{CF}_{2} \mathrm{CF}_{2} \mathrm{SO}_{3} \mathrm{H}^{-}\left({ }^{32} \mathrm{~S}\right)$ \\
\hline 183.2 & 2.71 & $\mathrm{CF}_{2} \mathrm{CF}_{2} \mathrm{SO}_{3} \mathrm{H}^{-}\left({ }^{34} \mathrm{~S}\right)$ \\
\hline 209.2 & 2.91 & \\
\hline 229.2 & 3.02 & \\
\hline 231.2 & 4.82 & \\
\hline 243.2 & 2.41 & \\
\hline 248.2 & 2.71 & \\
\hline 249.2 & 2.81 & \\
\hline 261.1 & 11.56 & $(\mathrm{M}-2 \mathrm{Li}+\mathrm{H})^{-}$ \\
\hline 266.2 & 6.53 & $(\mathrm{M}-\mathrm{Li})^{-}\left({ }^{6} \mathrm{Li},{ }^{32} \mathrm{~S}\right)$ \\
\hline 267.2 & 100.00 & $(\mathrm{M}-\mathrm{Li})^{-}\left({ }^{7} \mathrm{Li},{ }^{32} \mathrm{~S}\right)$ \\
\hline 268.2 & 6.43 & $(\mathrm{M}-\mathrm{Li})^{-}\left({ }^{6} \mathrm{Li},{ }^{34} \mathrm{~S}\right)$ \\
\hline 269.2 & 8.24 & $(\mathrm{M}-\mathrm{Li})^{-}\left({ }^{7} \mathrm{Li},{ }^{34} \mathrm{~S}\right)$ \\
\hline 277.2 & 9.75 & $\left(3 \mathrm{C}_{3} \mathrm{H}_{8} \mathrm{O}_{3} \cdot \mathrm{H}\right)^{\cdot}$ \\
\hline
\end{tabular}




\begin{tabular}{|c|c|c|}
\hline Mass & Rel. Int. & Type \\
\hline 281.2 & 12.56 & $\left(3 \mathrm{C}_{3} \mathrm{H}_{8} \mathrm{O}_{3}-2 \mathrm{H}+\mathrm{Li}\right)^{-}$ \\
\hline 293.2 & 3.82 & \\
\hline 349.2 & 3.82 & \\
\hline 354.2 & 2.21 & \\
\hline 361.2 & 5.13 & $\left(\mathrm{M} \cdot \mathrm{SO}_{3} \mathrm{Li}\right)^{-}$ \\
\hline 367.2 & 34.37 & $\left(2 \mathrm{M}-\mathrm{CF}_{2} \mathrm{CF}_{2} \mathrm{SO}_{3} \mathrm{H}\right)^{-}\left({ }^{7} \mathrm{Li},{ }^{32} \mathrm{~S}\right)$ \\
\hline 368.2 & 1.81 & $\left(2 \mathrm{M}-\mathrm{CF}_{2} \mathrm{CF}_{2} \mathrm{SO}_{3} \mathrm{H}\right) \cdot\left({ }^{6} \mathrm{Li},{ }^{34} \mathrm{~S}\right)$ \\
\hline 369.2 & 6.03 & $\left(2 \mathrm{M}-\mathrm{CF}_{2} \mathrm{CF}_{2} \mathrm{SO}_{3} \mathrm{H}\right) \cdot\left({ }^{7} \mathrm{Li},{ }^{34} \mathrm{~S}\right)$ \\
\hline 377.2 & 2.31 & \\
\hline 435.2 & 2.81 & \\
\hline 455.2 & 3.32 & \\
\hline 467.3 & 3.02 & \\
\hline 540.3 & 2.01 & $(2 \mathrm{M}-\mathrm{Li})^{-}\left({ }^{6} \mathrm{Li},{ }^{32} \mathrm{~S}\right)$ \\
\hline 541.3 & 11.16 & $(2 \mathrm{M}-\mathrm{Li})^{-}\left({ }^{7} \mathrm{Li},{ }^{32} \mathrm{~S}\right)$ \\
\hline 543.3 & 1.71 & $(2 \mathrm{M}-\mathrm{Li})^{\cdot}\left({ }^{7} \mathrm{Li},{ }^{34} \mathrm{~S}\right)$ \\
\hline 641.4 & 1.81 & \\
\hline
\end{tabular}


TABLE XIII

$\mathrm{CF}_{2}\left(\mathrm{CF}_{2} \mathrm{SO}_{2} \mathrm{OLi}\right)_{2} \quad$ M.W. 324

\begin{tabular}{|c|c|c|}
\hline Positive & & \\
\hline Mass & Rel. Int. & Type \\
\hline 31.1 & 13.47 & $\mathrm{CF}^{+}$ \\
\hline 32.1 & 4.22 & $\mathrm{CHF}^{+}$ \\
\hline 33.1 & 29.09 & $\mathrm{CH}_{2} \mathrm{~F}^{+}$ \\
\hline 57.2 & 3.59 & $\mathrm{C}_{3} \mathrm{H}_{5} \mathrm{O}^{+}$ \\
\hline 59.2 & 5.63 & $\mathrm{C}_{3} \mathrm{H}_{7} \mathrm{O}^{+}$ \\
\hline 73.2 & 2.70 & $\mathrm{C}_{3} \mathrm{H}_{5} \mathrm{O}_{2}^{+}$ \\
\hline 94.1 & 2.46 & $\left(\mathrm{C}_{3} \mathrm{H}_{8} \mathrm{O}_{3} \cdot 2 \mathrm{H}\right)^{+}$ \\
\hline 98.2 & 8.63 & $\left(\mathrm{C}_{3} \mathrm{H}_{8} \mathrm{O}_{3} \cdot \mathrm{Li}\right)^{+}\left({ }^{6} \mathrm{Li}\right)$ \\
\hline 99.2 & 100.00 & $\left(\mathrm{C}_{3} \mathrm{H}_{8} \mathrm{O}_{3} \cdot \mathrm{Li}\right)^{+}\left({ }^{7} \mathrm{Li}\right), \mathrm{CSO}_{3} \mathrm{Li}^{+}$ \\
\hline 101.1 & 3.53 & $\mathrm{CF}_{2} \mathrm{CF}_{2} \mathrm{H}^{+}$ \\
\hline 104.2 & 5.96 & $\left(\mathrm{C}_{3} \mathrm{H}_{7} \mathrm{O}_{3} \cdot 2 \mathrm{Li}\right)^{+}\left({ }^{6} \mathrm{Li}\right)$ \\
\hline 105.2 & 37.08 & $\left(\mathrm{C}_{3} \mathrm{H}_{7} \mathrm{O}_{3} \cdot 2 \mathrm{Li}\right)^{+}\left({ }^{7} \mathrm{Li}\right)$ \\
\hline 111.2 & 3.67 & $\mathrm{CFSO}_{3}^{+}$ \\
\hline 155.2 & 9.09 & $\mathrm{CF}_{2} \mathrm{CF}_{2} \mathrm{SOLi}^{+}$ \\
\hline 191.2 & 2.16 & $\left(2 \mathrm{C}_{3} \mathrm{H}_{8} \mathrm{O}_{3} \cdot \mathrm{Li}\right)^{+}$ \\
\hline 201.3 & 1.73 & \\
\hline 245.1 & 1.35 & \\
\hline 331.1 & 1.54 & \\
\hline
\end{tabular}


TABLE XIV

$\mathrm{CF}_{2}\left(\mathrm{CF}_{2} \mathrm{SO}_{2} \mathrm{OLi}\right)_{2} \quad$ M.W. 324

\begin{tabular}{|c|c|c|}
\hline \multicolumn{2}{|c|}{ Negative } & \multirow[b]{2}{*}{ Type } \\
\hline Mass & Rel. Int. & \\
\hline 80.1 & 17.22 & $\mathrm{SO}_{3}^{-}, \mathrm{C}_{2} \mathrm{~F}_{2} \cdot \mathrm{H}_{2} \mathrm{O}^{-}$ \\
\hline 130.1 & 4.00 & $\mathrm{CF}_{2} \mathrm{SO}_{3}^{-}$ \\
\hline 211.2 & 22.51 & $\mathrm{CF}_{2} \mathrm{CFCF}_{2} \mathrm{SO}_{3}^{-}$ \\
\hline 227.2 & 27.40 & $\left(2 \mathrm{C}_{3} \mathrm{H}_{8} \mathrm{O}_{3} \cdot \mathrm{C}_{2} \mathrm{H}_{3} \mathrm{O}\right)^{-}$ \\
\hline 230.2 & 6.79 & $\mathrm{CF}_{2} \mathrm{CF}_{2} \mathrm{CF}_{2} \mathrm{SO}_{3} \cdot\left({ }^{32} \mathrm{~S}\right)$ \\
\hline 231.2 & 71.67 & $\mathrm{CF}_{2} \mathrm{CF}_{2} \mathrm{CF}_{2} \mathrm{SO}_{3} \mathrm{H}^{-}\left({ }^{32} \mathrm{~S}\right)$ \\
\hline 232.2 & 2.31 & $\mathrm{CF}_{2} \mathrm{CF}_{2} \mathrm{CF}_{2} \mathrm{SO}_{3} \cdot\left({ }^{34} \mathrm{~S}\right)$ \\
\hline 233.2 & 2.66 & $\mathrm{CF}_{2} \mathrm{CF}_{2} \mathrm{CF}_{2} \mathrm{SO}_{3} \mathrm{H}^{-}\left({ }^{34} \mathrm{~S}\right)$ \\
\hline 279.2 & 3.69 & $\mathrm{OSCF}_{2} \mathrm{CF}_{2} \mathrm{CF}_{2} \mathrm{SO}_{3} \mathrm{H}^{-}$ \\
\hline 298.2 & 3.82 & \\
\hline 299.2 & 2.84 & \\
\hline 311.2 & 3.86 & \\
\hline 316.2 & 6.66 & $(\mathrm{M}-\mathrm{Li})^{-}\left({ }^{6} \mathrm{Li},{ }^{32} \mathrm{~S}\right)$ \\
\hline 317.2 & 100.00 & $(\mathrm{M}-\mathrm{Li}) \cdot\left({ }^{7} \mathrm{Li},{ }^{32} \mathrm{~S}\right)$ \\
\hline 318.2 & 6.88 & $(\mathrm{M}-\mathrm{Li})^{-}\left({ }^{6} \mathrm{Li},{ }^{34} \mathrm{~S}\right)$ \\
\hline 319.2 & 8.97 & $(\mathrm{M}-\mathrm{Li})^{-}\left({ }^{7} \mathrm{Li},{ }^{34} \mathrm{~S}\right)$ \\
\hline 343.2 & 3.77 & $(M \cdot F)^{-}$ \\
\hline 449.2 & 4.22 & \\
\hline 467.2 & 3.15 & $\left(5 \mathrm{C}_{3} \mathrm{H}_{8} \mathrm{O}_{3} \cdot \mathrm{Li}\right)^{-}$ \\
\hline 469.2 & 2.93 & \\
\hline 535.2 & 2.71 & \\
\hline 555.3 & 5.60 & $\left(\mathrm{M}-\mathrm{CF}_{2} \mathrm{CF}_{2} \mathrm{CF}_{2} \mathrm{SO}_{3} \mathrm{H}\right)^{-}$ \\
\hline 640.4 & 1.55 & $(2 \mathrm{M}-\mathrm{Li})^{-}\left({ }^{6} \mathrm{Li},{ }^{32} \mathrm{~S}\right)$ \\
\hline 641.4 & 10.35 & $(2 \mathrm{M}-\mathrm{Li})^{-}\left({ }^{7} \mathrm{Li},{ }^{32} \mathrm{~S}\right)$ \\
\hline 642.4 & 1.15 & $(2 \mathrm{M}-\mathrm{Li})^{-}\left({ }^{6} \mathrm{Li},{ }^{34} \mathrm{~S}\right)$ \\
\hline
\end{tabular}




\begin{tabular}{|c|c|c|}
\hline Mass & Rel. Int. & \multicolumn{1}{|c|}{ Type } \\
\hline 643.3 & 1.87 & $(2 \mathrm{M} \cdot \mathrm{Li})^{-}\left({ }^{7} \mathrm{Li},{ }^{34} \mathrm{~S}\right)$ \\
\hline
\end{tabular}

TABLE XV

$$
\begin{array}{ll}
\left(\mathrm{CF}_{2} \mathrm{CF}_{2} \mathrm{SO}_{2} \mathrm{OLi}\right)_{2} & \text { M.W. } 324
\end{array}
$$

\begin{tabular}{|c|c|c|}
\hline Positive & & \\
\hline Mass & Rel. Int. & Type \\
\hline 31.1 & 12.38 & $\mathrm{CF}^{+}$ \\
\hline 32.1 & 3.65 & $\mathrm{CHF}^{+}$ \\
\hline 33.1 & 25.08 & $\mathrm{CH}_{2} \mathrm{~F}^{+}$ \\
\hline 57.2 & 2.76 & $\mathrm{C}_{3} \mathrm{H}_{5} \mathrm{O}^{+}$ \\
\hline 59.1 & 3.81 & $\mathrm{C}_{3} \mathrm{H}_{7} \mathrm{O}^{+}$ \\
\hline 73.1 & 2.16 & $\mathrm{C}_{3} \mathrm{H}_{5} \mathrm{O}_{2}^{+}$ \\
\hline 94.1 & 3.28 & $\left(\mathrm{C}_{3} \mathrm{H}_{8} \mathrm{O}_{3} \cdot 2 \mathrm{H}\right)^{+}$ \\
\hline 98.1 & 8.48 & $\left(\mathrm{C}_{3} \mathrm{H}_{8} \mathrm{O}_{3} \cdot \mathrm{Li}\right)^{+}\left({ }^{6} \mathrm{Li}\right)$ \\
\hline 99.1 & 100.00 & $\left(\mathrm{C}_{3} \mathrm{H}_{8} \mathrm{O}_{3} \cdot \mathrm{Li}\right)^{+}\left({ }^{7} \mathrm{Li}\right), \mathrm{CSO}_{3} \mathrm{Li}^{+}$ \\
\hline 100.1 & 3.07 & $\mathrm{CF}_{2} \mathrm{CF}_{2}{ }^{+}$ \\
\hline 104.2 & 5.04 & $\left(\mathrm{C}_{3} \mathrm{H}_{8} \mathrm{O}_{3} \cdot 2 \mathrm{Li}\right)^{+}\left({ }^{6} \mathrm{Li}\right)$ \\
\hline 105.2 & 32.26 & $\left(\mathrm{C}_{3} \mathrm{H}_{8} \mathrm{O}_{3} \cdot 2 \mathrm{Li}\right)^{+}\left({ }^{7} \mathrm{Li}\right)$ \\
\hline 111.2 & 3.21 & $\mathrm{CFSO}_{3}^{+}$ \\
\hline 155.2 & 4.68 & $\mathrm{CF}_{2} \mathrm{CF}_{2} \mathrm{SOLi}^{+}$ \\
\hline 201.3 & 2.05 & \\
\hline
\end{tabular}


TABLE XVI

$\begin{array}{ll}\left(\mathrm{CF}_{2} \mathrm{CF}_{2} \mathrm{SO}_{2} \mathrm{OII}\right)_{2} & \text { M.W. } 374\end{array}$

\begin{tabular}{|c|c|c|}
\hline \multicolumn{2}{|c|}{ Negative } & \multirow[b]{2}{*}{ Type } \\
\hline Mass & Rel. Int. & \\
\hline 19.1 & 2.99 & $F^{-}$ \\
\hline 80.1 & 19.11 & $\mathrm{SO}_{3} ; \mathrm{C}_{2} \mathrm{~F}_{2} \cdot \mathrm{H}_{2} \mathrm{O}$ \\
\hline 99.1 & 2.49 & \\
\hline 130.1 & 7.71 & $\left(\mathrm{C}_{3} \mathrm{H}_{4} \mathrm{O} \cdot \mathrm{C}_{3} \mathrm{H}_{6} \mathrm{O}_{2}\right)^{-}$ \\
\hline 131.2 & 3.43 & $\mathrm{C}_{3} \mathrm{~F}_{5}^{-}$ \\
\hline 161.1 & 2.66 & $\mathrm{CF}_{2} \mathrm{CFSO}_{3}{ }^{-}$ \\
\hline 180.1 & 2.15 & \\
\hline 243.2 & 4.91 & \\
\hline 261.2 & 38.61 & $\mathrm{C}_{4} \mathrm{~F}_{7} \mathrm{SO}_{3} \cdot\left({ }^{32} \mathrm{~S}\right)$ \\
\hline 262.2 & 2.25 & \\
\hline 263.2 & 2.76 & $\mathrm{C}_{4} \mathrm{~F}_{7} \mathrm{SO}_{3} \cdot\left({ }^{34} \mathrm{~S}\right)$ \\
\hline 277.2 & 23.65 & $\left(3 \mathrm{C}_{3} \mathrm{H}_{8} \mathrm{O}_{3} \cdot \mathrm{H}\right)^{-}$ \\
\hline 280.2 & 4.27 & $\left(\mathrm{CF}_{2}\right)_{4} \mathrm{SO}_{3}^{-}$ \\
\hline 281.2 & 37.21 & $\left(\mathrm{CF}_{2}\right)_{4} \mathrm{SO}_{3} \mathrm{H}^{-}$ \\
\hline 329.2 & 4.74 & \\
\hline 348.2 & 2.09 & \\
\hline 249.2 & 3.87 & \\
\hline 366.2 & 7.60 & $(\mathrm{M}-\mathrm{Li})^{-}\left({ }^{6} \mathrm{Li},{ }^{32} \mathrm{~S}\right)$ \\
\hline 367.2 & 100.00 & $(\mathrm{M}-\mathrm{Li})^{-}\left({ }^{7} \mathrm{Li},{ }^{32} \mathrm{~S}\right)$ \\
\hline 368.2 & 7.13 & $(\mathrm{M}-\mathrm{Li})^{-}\left({ }^{6} \mathrm{Li},{ }^{34} \mathrm{~S}\right)$ \\
\hline 369.2 & 9.93 & $(\mathrm{M}-\mathrm{Li})^{-}\left({ }^{7} \mathrm{Li},{ }^{34} \mathrm{~S}\right),\left(4 \mathrm{C}_{3} \mathrm{H}_{8} \mathrm{O}_{3} \cdot \mathrm{H}\right)^{-}$ \\
\hline 393.3 & 3.26 & $(M \cdot F)^{-}$ \\
\hline 741.4 & 6.33 & $(2 M-L i)^{-}$ \\
\hline
\end{tabular}


TABLE XVII

$\mathrm{O}\left(\mathrm{CF}_{2} \mathrm{CF}_{2} \mathrm{SO}_{2} \mathrm{OLi}\right)_{2} \quad$ M.W. 390

\begin{tabular}{|c|c|c|}
\hline Positive & & \\
\hline Mass & Rel. Int. & Type \\
\hline 18.1 & 3.67 & $\mathrm{H}_{2} \mathrm{O}^{+}$ \\
\hline 31.1 & 12.40 & $\mathrm{CF}^{+}$ \\
\hline 33.1 & 31.66 & $\mathrm{CH}_{2} \mathrm{~F}^{+}$ \\
\hline 57.1 & 3.57 & $\mathrm{C}_{3} \mathrm{H}_{5} \mathrm{O}^{+}$ \\
\hline 59.1 & 6.15 & $\mathrm{C}_{3} \mathrm{H}_{7} \mathrm{O}^{+}$ \\
\hline 73.2 & 11.44 & $\mathrm{C}_{3} \mathrm{H}_{5} \mathrm{O}_{2}{ }^{+}$ \\
\hline 94.1 & 4.20 & $\left(\mathrm{C}_{3} \mathrm{H}_{8} \mathrm{O}_{3} \cdot 2 \mathrm{H}\right)^{+}$ \\
\hline 98.1 & 9.65 & $\left(\mathrm{C}_{3} \mathrm{H}_{8} \mathrm{O}_{3} \cdot \mathrm{Li}\right)^{+}\left({ }^{6} \mathrm{Li}\right) ; \mathrm{CF}_{2} \mathrm{SO}^{+}$ \\
\hline 99.2 & 100.00 & $\left(\mathrm{C}_{3} \mathrm{H}_{8} \mathrm{O}_{3} \cdot \mathrm{Li}\right)^{+}\left({ }^{7} \mathrm{Li}\right), \mathrm{CSO}_{3} \mathrm{Li}^{+}$ \\
\hline 100.1 & 3.80 & $\mathrm{CF}_{2} \mathrm{CF}_{2}^{+}$ \\
\hline 101.1 & 2.39 & $\mathrm{CF}_{2} \mathrm{CF}_{2} \mathrm{H}^{+}$ \\
\hline 104.2 & 5.05 & $\left(\mathrm{C}_{3} \mathrm{H}_{7} \mathrm{O}_{3} \cdot 2 \mathrm{Li}\right)^{+}\left({ }^{(} \mathrm{Li}\right)$ \\
\hline 105.2 & 34.19 & $\left(\mathrm{C}_{3} \mathrm{H}_{7} \mathrm{O}_{3} \cdot 2 \mathrm{Li}\right)^{+}\left({ }^{7} \mathrm{Li}\right)$ \\
\hline 111.2 & 3.91 & $\mathrm{CFSO}_{3}^{+}$ \\
\hline 155.2 & 5.23 & $\mathrm{CF}_{2} \mathrm{CF}_{2} \mathrm{SOLi}^{+}$ \\
\hline 191.2 & 2.32 & $\left(\mathrm{C}_{3} \mathrm{H}_{8} \mathrm{O}_{3} \cdot \mathrm{Li}\right)^{+}$ \\
\hline
\end{tabular}


TABLE XVIII

$\mathrm{O}\left(\mathrm{CF}_{2} \mathrm{CF}_{2} \mathrm{SO}_{2} \mathrm{OLi}\right)_{2} \quad$ M.W. 390

\begin{tabular}{|c|c|c|}
\hline \multicolumn{2}{|c|}{ Negative } & \multirow[b]{2}{*}{ Type } \\
\hline Mass & Rel. Int. & \\
\hline 80.1 & 6.94 & $\mathrm{SO}_{3} ; \mathrm{C}_{2} \mathrm{~F}_{2} \cdot \mathrm{H}_{2} \mathrm{O}^{-}$ \\
\hline 97.1 & 2.20 & \\
\hline 113.1 & 5.39 & $\left(2 \mathrm{C}_{3} \mathrm{H}_{5} \mathrm{O}-\mathrm{H}\right)^{-}$ \\
\hline 117.1 & 2.48 & $\mathrm{HOCF}_{2} \mathrm{CF}_{2}^{-}$ \\
\hline 161.1 & 2.00 & $\mathrm{CF}_{2} \mathrm{CFSO}_{3}^{\circ}$ \\
\hline 177.2 & 22.94 & $\mathrm{OCF}_{2} \mathrm{CFSO}_{3}$ \\
\hline 203.2 & 3.50 & \\
\hline 277.2 & 5.30 & $\mathrm{CFCF}_{2} \mathrm{O}\left(\mathrm{CF}_{2}\right)_{2} \mathrm{SO}_{3}^{-}$ \\
\hline 293.2 & 5.68 & $\left(3 \mathrm{C}_{3} \mathrm{H}_{8} \mathrm{O}_{3} \mathrm{OH}\right)$ \\
\hline 296.2 & 3.63 & $\mathrm{OSO}_{2}\left(\mathrm{CF}_{2}\right)_{2} \mathrm{O}\left(\mathrm{CF}_{2}\right)_{2}^{-}$ \\
\hline 297.2 & 11.95 & $\mathrm{HOSO}_{2}\left(\mathrm{CF}_{2}\right)_{2} \mathrm{O}\left(\mathrm{CF}_{2}\right)_{2}^{-}$ \\
\hline 365.2 & 3.99 & \\
\hline 382.2 & 7.35 & $(\mathrm{M}-\mathrm{Li})^{-}\left({ }^{6} \mathrm{Li},{ }^{32} \mathrm{~S}\right)$ \\
\hline 383.2 & 100.00 & $(\mathrm{M}-\mathrm{Li})^{-}\left({ }^{7} \mathrm{Li},{ }^{32} \mathrm{~S}\right)$ \\
\hline 384.3 & 6.45 & $(\mathrm{M}-\mathrm{Li})^{-}\left({ }^{6} \mathrm{Li},{ }^{34} \mathrm{~S}\right)$ \\
\hline 385.2 & 9.74 & $(\mathrm{M}-\mathrm{Li})^{-}\left({ }^{7} \mathrm{Li},{ }^{34} \mathrm{~S}\right)$ \\
\hline 599.4 & 1.27 & \\
\hline 773.4 & 2.61 & $(2 \mathrm{M}-\mathrm{Li})^{-}$ \\
\hline
\end{tabular}


IR SPECTRA

The infrared spectra of the lithium salts of the pentafluorothio alkyl and perfluoroalkane sulfonic acids are given in Tables XIX-XXVII.

The pentafluorothio alkyl sulfonic acid salts have among their main features the S-F stretching mode at 830-910 $\mathrm{Cm}^{-1} 87,110,111$; the $\mathrm{S}-\mathrm{F}$ deformation mode at $580-615 \mathrm{~cm}^{-1} 110,111$ is weaker. It is likely then that one should assign the 835 $\mathrm{Cm}^{-1}$ peak of $\mathrm{SF}_{5} \mathrm{CH}_{2} \mathrm{CH}_{2} \mathrm{SO}_{2} \mathrm{OLi}$, the 836 peak of $\mathrm{SF}_{5} \mathrm{CH}_{2} \mathrm{CF}_{2} \mathrm{SO}_{2} \mathrm{OLi}$, and the $861 \mathrm{~cm}^{-1}$ peak of $\mathrm{SF}_{5} \mathrm{CHFCF}_{2} \mathrm{SO}_{2} \mathrm{OLi}$ to the S-F stretch, while interpreting the $609 \mathrm{~cm}^{-1}$ absorbance of $\mathrm{SF}_{5} \mathrm{CH}_{2} \mathrm{CH}_{2} \mathrm{SO}_{2} \mathrm{OLi}$, the $614 \mathrm{~cm}^{-1}$ absorbance of $\mathrm{SF}_{5} \mathrm{CH}_{2} \mathrm{CF}_{2} \mathrm{SO}_{2} \mathrm{OLi}$ and the $609 \mathrm{~cm}^{-1}$ absorbance of $\mathrm{SF}_{5} \mathrm{CHFCF}_{2} \mathrm{SO}_{2} \mathrm{OLi}$ as due to the S-F deformation.

Each of these salts has a $\mathrm{C}-\mathrm{H}$ bond in it, but the characteristic $\mathrm{C}-\mathrm{H}$ stretch absorption near $3000 \mathrm{~cm}^{-1} 112,113$ was not always clear. There is a weak peak at $3002 \mathrm{~cm}^{-1}$ in $\mathrm{SF}_{5} \mathrm{CH}_{2} \mathrm{CF}_{2} \mathrm{SO}_{2} \mathrm{OLi}$ and at $3023 \mathrm{~cm}^{-1}$ in $\mathrm{SF}_{5} \mathrm{CHFCF}_{2} \mathrm{SO}_{2} \mathrm{OLi}$. This characteristic absorption is a weak one, though ${ }^{112}$, so the result should not be unexpected.

An unfortunate feature of the fluorinated sulfonic acids, at least from the standpoint of infrared spectrum interpretation, is that the $1000-1400 \mathrm{~cm}^{-1}$ region is so complex. Carbon-carbon stretching vibrations appear in this region, ${ }^{112,114}$ and vibrational interactions for fluoro compounds are strong here. ${ }^{112,113}$ The $1000-1100 \mathrm{~cm}^{-1}$ frequency range for $C-F$ stretching vibrations ${ }^{86,112}$ and the $1100-1300$ 
$\mathrm{Cm}^{-1}$ frequency range for $\mathrm{CF}_{2}$ stretching vibrations ${ }^{87,112,113}$ overlap the $\mathrm{SO}_{3}$ symmetric stretch range $1050-1100 \mathrm{~cm}^{-1} 87,88,115$ and the $\mathrm{SO}_{3}$ asymmetric stretch range $1180-1280 \mathrm{~cm}^{-1} \cdot{ }^{87,88,115}$ As a result, unambiguous assignment of the vibrational modes involved is not possible.

Educated conjecture, however, is always possible. Assuming that the $\mathrm{SO}_{3}$ symmetric and asymmetric stretches will be good-sized peaks, that the asymmetric stretch will frequently be close to $1245-1250 \mathrm{~cm}^{-1}$ for our compounds 116 and that the symmetric stretch will be about $1059-1100 \mathrm{~cm}^{-1}$ for our compounds, assignments can be made. Asymmetric stretches will be found at $1189 \mathrm{~cm}^{-1}$ for $\mathrm{SF}_{5} \mathrm{CH}_{2} \mathrm{CH}_{2} \mathrm{SO}_{2} \mathrm{OLi}, 1223$ $\mathrm{Cm}^{-1}$ for $\mathrm{SF}_{5} \mathrm{CH}_{2} \mathrm{CF}_{2} \mathrm{SO}_{3} \mathrm{Li}$, and $1241 \mathrm{~cm}^{-1}$ for $\mathrm{SF}_{5} \mathrm{CHFCF}_{2} \mathrm{SO}_{3} \mathrm{Li}$. Symmetric stretches will be responsible for the peaks at $1084 \mathrm{~cm}^{-1}$ for $\mathrm{SF}_{5} \mathrm{CH}_{2} \mathrm{CH}_{2} \mathrm{SO}_{3} \mathrm{Li}$ and $1095 \mathrm{~cm}^{-1}$ for $\mathrm{SF}_{5} \mathrm{CH}_{2} \mathrm{CF}_{2} \mathrm{SO}_{3} \mathrm{Li}$; $1105 \mathrm{~cm}^{-1}$ for $\mathrm{SF}_{5} \mathrm{CHFCF}_{2} \mathrm{SO}_{3} \mathrm{Li}$.

The Li-O stretch is so variable that no characteristic frequency range can be given for it. ${ }^{117}$

Assignments for the perfluoroalkane disulfonic acid disalts will also have to be made on the basis of educated conjecture, because the characteristic $\mathrm{SO}_{3}$ and $\mathrm{CF}_{2}$ stretch ranges overlap.

Asymmetric $\mathrm{SO}_{3}$ stretching peaks will be the $1265 \mathrm{~cm}^{-1}$ for $\mathrm{CF}_{2}\left(\mathrm{SO}_{2} \mathrm{OLi}\right)_{2}, 1251 \mathrm{~cm}^{-1}$ for $\left(\mathrm{CF}_{2} \mathrm{SO}_{2} \mathrm{OLi}\right)_{2}, 1248 \mathrm{~cm}^{-1}$ for $\mathrm{CF}_{2}\left(\mathrm{CF}_{2} \mathrm{SO}_{2} \mathrm{OLi}\right)_{2}$ and $1253 \mathrm{~cm}^{-1}$ for $\left(\mathrm{CF}_{2} \mathrm{CF}_{2} \mathrm{SO}_{2} \mathrm{OLi}\right)_{2}$. Symmetric $\mathrm{SO}_{3}$ stretches will be seen at $1072 \mathrm{~cm}^{-1}$ for $\mathrm{CF}_{2}\left(\mathrm{SO}_{2} \mathrm{OLi}\right)_{2}, 1056$ 
$\mathrm{Cm}^{-1}$ for $\left(\mathrm{CF}_{2} \mathrm{SO}_{2} \mathrm{OLi}\right)_{2}, 1063 \mathrm{~cm}^{-1}$ for $\mathrm{CF}_{2}\left(\mathrm{CF}_{2} \mathrm{SO}_{2} \mathrm{OLi}\right)_{2}$ and 1044 $\mathrm{Cm}^{-1}$ for $\left(\mathrm{CF}_{2} \mathrm{CF}_{2} \mathrm{SO}_{2} \mathrm{OLi}\right)_{2}$. Perhaps we see $\mathrm{CF}_{2}$ stretches at 1117, 1223, $1285 \mathrm{~cm}^{-1}$ in the $\mathrm{CF}_{2}\left(\mathrm{SO}_{3} \mathrm{Li}\right)_{2}$ spectrum, at 1137 , 1152, 1271, and $1300 \mathrm{~cm}^{-1}$ in the $\left(\mathrm{CF}_{2} \mathrm{SO}_{3} \mathrm{Li}\right)_{2}$ spectrum, at 1148, 1161 and $1175 \mathrm{~cm}^{-1}$ in the $\mathrm{CF}_{2}\left(\mathrm{CF}_{2} \mathrm{SO}_{3} \mathrm{Li}\right)_{2}$ spectrum, and at 1124,1164 and $1187 \mathrm{~cm}^{-1}$ in the $\left(\mathrm{CF}_{2} \mathrm{CF}_{2} \mathrm{SO}_{3} \mathrm{Li}\right)_{2}$ spectrum.

The ether salt $\mathrm{O}\left(\mathrm{CF}_{2} \mathrm{CF}_{2} \mathrm{SO}_{2} \mathrm{OLi}\right)_{2}$ will have asymmetric $\mathrm{SO}_{3}$

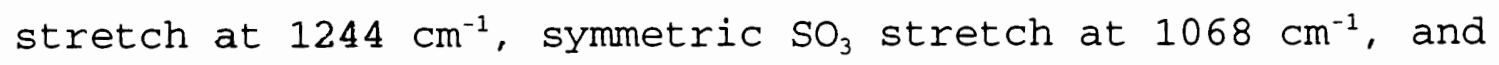
$\mathrm{CF}_{2}$ stretch at $1280 \mathrm{~cm}^{-1}$. The ether salt has a $\mathrm{C}-\mathrm{O}-\mathrm{C}$ stretch. Infrared absorption band for this stretch is located in the $1060-1150 \mathrm{~cm}^{-1}$ region ${ }^{118}$, so we can possibly assign the $1165 \mathrm{~cm}^{-1}$ absorbance as a C-O-C stretch.

The infrared spectrum of the polymer of $\mathrm{OCH}_{2}-\mathrm{CH}-\mathrm{CH}_{2}-\mathrm{OCF}_{2} \mathrm{CF}_{2} \mathrm{SO}_{2} \mathrm{OLi}$ shows no sign of the $\mathrm{S}-\mathrm{F}$ stretching mode around $800 \mathrm{~cm}^{-1} 85.86$ that is a characteristic of the sulfonyl fluoride from which it was made; the polymer is now present at the salt. There is a broad absorption at $1260 \mathrm{~cm}^{-1}$ that not only contains the asymmetric $\mathrm{SO}_{3}$ stretch (cf. the 1266-1279 $\mathrm{cm}^{-1}$ peak found for the triflate ion ${ }^{86}$ ), but also a buried symmetric $\mathrm{SO}_{3}$ stretch as well. It is known that the asymmetric stretch is present because a spectrum of the original polymer 119 shows no absorbance between $1245 \mathrm{~cm}^{-1}$ and $1335 \mathrm{~cm}^{-1}$.

The $\mathrm{C}-\mathrm{H}$ stretch near $3000 \mathrm{~cm}^{-1}$ is a shoulder nearly hidden in the water peak at $3519 \mathrm{~cm}^{-1}$. The broad band at $1115 \mathrm{~cm}^{-1}$ is probably due to a $\mathrm{C}-\mathrm{O}-\mathrm{C}$ stretch and a $\mathrm{CF}_{2}$ 
stretch.

TABLE XIX

IR DATA FOR $\mathrm{SF}_{5} \mathrm{CH}_{2} \mathrm{CH}_{2} \mathrm{SO}_{2} \mathrm{OLi}\left(\mathrm{cm}^{-1}\right)$

\begin{tabular}{|l|l|}
\hline $3578(\mathrm{~m})$ & $994(\mathrm{~m})$ \\
\hline $3522(\mathrm{~m})$ & $912(\mathrm{~m})$ \\
\hline $1638(\mathrm{~m})$ & $835(\mathrm{st}, \mathrm{br})$ \\
\hline $1438(\mathrm{w}, \mathrm{sh})$ & $805(\mathrm{w}, \mathrm{sh})$ \\
\hline $1427(\mathrm{w})$ & $705(\mathrm{w})$ \\
\hline $1264(\mathrm{~m})$ & $609(\mathrm{~m}, \mathrm{sh})$ \\
\hline $1238(\mathrm{~m}, \mathrm{sh})$ & $587(\mathrm{~m}, \mathrm{sh})$ \\
\hline $1190(\mathrm{st})$ & $568(\mathrm{st})$ \\
\hline $1157(\mathrm{~m})$ & $535(\mathrm{w})$ \\
\hline $1083(\mathrm{~m})$ & $465(\mathrm{w})$ \\
\hline $1072(\mathrm{~m})$ & $431(\mathrm{w})$ \\
\hline
\end{tabular}


TABLE XX

IR DATA FOR $\mathrm{SF}_{5} \mathrm{CH}_{2} \mathrm{CF}_{2} \mathrm{SO}_{2} \mathrm{OLI}\left(\mathrm{cm}^{-1}\right)$

\begin{tabular}{||l|l|}
\hline $3663(w, s h)$ & $1001(s t)$ \\
\hline $3543(w, s h)$ & $917(s t)$ \\
\hline $3466(\mathrm{~m}, \mathrm{br})$ & $900(\mathrm{st})$ \\
\hline $3128(w)$ & $836(\mathrm{st}, \mathrm{br})$ \\
\hline $3051(w)$ & $803(\mathrm{st}, \mathrm{sh})$ \\
\hline $3002(w)$ & $712(w)$ \\
\hline $1680(w)$ & $678(\mathrm{st})$ \\
\hline $1645(w)$ & $634(\mathrm{~m})$ \\
\hline $1418(\mathrm{~m})$ & $614(\mathrm{~m})$ \\
\hline $1337(w, s h)$ & $570(\mathrm{~m})$ \\
\hline $1287(\mathrm{st})$ & $557(\mathrm{~m}, \mathrm{sh})$ \\
\hline $1223(\mathrm{st}, \mathrm{br})$ & $537(w)$ \\
\hline $1122(\mathrm{~m}, \mathrm{sh})$ & $439(\mathrm{w})$ \\
\hline $1095(\mathrm{st})$ & \\
\hline $1062(\mathrm{st})$ & \\
\hline
\end{tabular}


TABLE XXI

IR DATA FOR $\mathrm{SF}_{5} \mathrm{CHFCF}_{2} \mathrm{SO}_{2} \mathrm{OLi}\left(\mathrm{cm}^{-1}\right)$

\begin{tabular}{||l|l|}
\hline $3536(\mathrm{~m})$ & $923(\mathrm{st}, \mathrm{sh})$ \\
\hline $3487(\mathrm{~m}, \mathrm{sh})$ & $861(\mathrm{st}, \mathrm{br})$ \\
\hline $3023(\mathrm{w})$ & $811(\mathrm{~m})$ \\
\hline $2341(\mathrm{w})$ & $733(\mathrm{w}, \mathrm{sh})$ \\
\hline $1645(\mathrm{~m})$ & $692(\mathrm{w}, \mathrm{sh})$ \\
\hline $1362(\mathrm{w}, \mathrm{sh})$ & $657(\mathrm{~m})$ \\
\hline $1289(\mathrm{st}, \mathrm{sh})$ & $609(\mathrm{~m})$ \\
\hline $1267(\mathrm{st})$ & $566(\mathrm{~m})$ \\
\hline $1241(\mathrm{st}, \mathrm{br})$ & $533(\mathrm{w}, \mathrm{sh})$ \\
\hline $1162(\mathrm{~m})$ & $514(\mathrm{~m})$ \\
\hline $1141(\mathrm{w}, \mathrm{sh})$ & $481(\mathrm{~m})$ \\
\hline $1122(\mathrm{~m})$ & $462(\mathrm{~m})$ \\
\hline $1105(\mathrm{w}, \mathrm{sh})$ & $455(\mathrm{~m})$ \\
\hline $1003(\mathrm{st})$ & $448(\mathrm{~m})$ \\
\hline
\end{tabular}


TABLE XXII

IR DATA FOR $\left(\mathrm{LiOSO}_{2}\right)_{2} \mathrm{CF}_{2}\left(\mathrm{~cm}^{-1}\right)$

\begin{tabular}{|l|l|}
\hline $3522(w)$ & $1072(\mathrm{~m})$ \\
\hline $3473(w)$ & $1055(w)$ \\
\hline $1631(w)$ & $1039(\mathrm{~m})$ \\
\hline $1497(w)$ & $955(w)$ \\
\hline $1434(w)$ & $938(w)$ \\
\hline $1286(s t, s h)$ & $711(w, s h)$ \\
\hline $1265(s t)$ & $698(\mathrm{~m})$ \\
\hline $1223(s t)$ & $620(w, s h)$ \\
\hline $1117(w)$ & $610(s t)$ \\
\hline $1085(w)$ & $568(w)$ \\
\hline & $545(w)$ \\
\hline
\end{tabular}


TABLE XXIII

IR DATA FOR $\left(\mathrm{CF}_{2} \mathrm{SO}_{2} \mathrm{OLi}\right)_{2} \quad\left(\mathrm{~cm}^{-1}\right)$

\begin{tabular}{||l|l|}
\hline $3571(w, s h)$ & $1137(\mathrm{~m}, \mathrm{sh})$ \\
\hline $3522(\mathrm{w})$ & $1081(\mathrm{~m})$ \\
\hline $3409(\mathrm{w}, \mathrm{br})$ & $1056(\mathrm{st})$ \\
\hline $1638(\mathrm{w})$ & $845(\mathrm{w})$ \\
\hline $1427(\mathrm{w})$ & $654(\mathrm{w}, \mathrm{sh})$ \\
\hline $1300(\mathrm{st}, \mathrm{sh})$ & $626(\mathrm{~m})$ \\
\hline $1272(\mathrm{st}, \mathrm{sh})$ & $561(\mathrm{~m})$ \\
\hline $1152(\mathrm{st})$ & $526(\mathrm{w})$ \\
\hline
\end{tabular}

TABLE XXIV

IR DATA FOR $\mathrm{CF}_{2}\left(\mathrm{CF}_{2} \mathrm{SO}_{2} \mathrm{OLi}\right)_{2} \quad\left(\mathrm{~cm}^{-1}\right)$

\begin{tabular}{||l|l|}
\hline $3592(w)$ & $987(w)$ \\
\hline $3508(w)$ & $847(w)$ \\
\hline $1638(m)$ & $780(w)$ \\
\hline $1317(s t, s h)$ & $712(w)$ \\
\hline $1305(s t, s h)$ & $666(s t, b r)$ \\
\hline $1248(s t, b r)$ & $607(w)$ \\
\hline $1175(m)$ & $584(w)$ \\
\hline $1161(m)$ & $569(w)$ \\
\hline $1148(m)$ & $546(w)$ \\
\hline $1100(m)$ & $532(w)$ \\
\hline $1063(s t)$ & $482(w)$ \\
\hline $1046(m, s h)$ & $461(w)$ \\
\hline $1012(m)$ & \\
\hline
\end{tabular}


TABLE XXV

IR DATA FOR $\left(\mathrm{CF}_{2} \mathrm{CF}_{2} \mathrm{SO}_{2} \mathrm{OLi}\right)_{2} \quad\left(\mathrm{~cm}^{-1}\right)$

\begin{tabular}{||l|l|}
\hline $3634(w, s h)$ & $1044(s t)$ \\
\hline $3501(\mathrm{~m})$ & $865(w)$ \\
\hline $3459(\mathrm{~m}, \mathrm{br})$ & $736(w)$ \\
\hline $1666(w, s h)$ & $730(w)$ \\
\hline $1631(\mathrm{~m})$ & $679(\mathrm{~m})$ \\
\hline $1518(w)$ & $619(\mathrm{~m})$ \\
\hline $1427(w)$ & $588(w)$ \\
\hline $1270(\mathrm{st})$ & $559(w)$ \\
\hline $1253(\mathrm{st}, \mathrm{sh})$ & $539(w)$ \\
\hline $1187(\mathrm{~m})$ & $493(w)$ \\
\hline $1164(\mathrm{~m})$ & $471(w)$ \\
\hline $1124(\mathrm{st})$ & \\
\hline
\end{tabular}


TABLE XXVI

IR DATA FOR ( $\left.\mathrm{LiOSO}_{2} \mathrm{CF}_{2} \mathrm{CF}_{2}\right)_{2} \mathrm{O} \quad\left(\mathrm{cm}^{-1}\right)$

\begin{tabular}{||l|l|}
\hline $3508(\mathrm{~m})$ & $850(w)$ \\
\hline $3445(\mathrm{~m}, \mathrm{sh}, \mathrm{br})$ & $749(w)$ \\
\hline $2924(\mathrm{w})$ & $670(w, s h)$ \\
\hline $2854(w)$ & $655(\mathrm{~m})$ \\
\hline $1642(\mathrm{~m})$ & $629(w, s h)$ \\
\hline $1346(\mathrm{~m}, \mathrm{sh})$ & $554(w)$ \\
\hline $1280(\mathrm{st}, \mathrm{sh})$ & $535(w)$ \\
\hline $1244(\mathrm{st})$ & $514(w)$ \\
\hline $1165(\mathrm{st})$ & $500(w)$ \\
\hline $1085(\mathrm{~m})$ & $489(w)$ \\
\hline $1068(\mathrm{~m})$ & $477(w)$ \\
\hline $1020(\mathrm{~m})$ & $462(w)$ \\
\hline $973(\mathrm{~m})$ & \\
\hline
\end{tabular}

TABLE XXVII

IR DATA FOR POLYMER OF $\overparen{\mathrm{OCH}_{2}-\mathrm{CH}}-\mathrm{CH}_{2}-0-\mathrm{CF}_{2} \mathrm{CF}_{2} \mathrm{SO}_{3} \mathrm{Li}$

\begin{tabular}{|l|l|}
\hline $3519(\mathrm{st}, \mathrm{v} \mathrm{br})^{\star}$ & $666(\mathrm{st})$ \\
\hline $1640(\mathrm{st})^{\star}$ & $630(\mathrm{st})$ \\
\hline $1406(\mathrm{~m})$ & $534(\mathrm{st})$ \\
\hline $1260(\mathrm{st})$ & $500(\mathrm{st})$ \\
\hline $1115(\mathrm{st})$ & \\
\hline $998(\mathrm{~m})$ & \\
\hline$*$ polymer salt contained water & \\
\hline
\end{tabular}


NUCLEAR MAGNETIC RESONANCE SPECTRA

${ }^{1} \mathrm{H},{ }^{19} \mathrm{~F}$ and ${ }^{13} \mathrm{C}$ nuclear magnetic resonance spectra of the pentafluorothio alkyl and perfluoroalkyl sulfonic acid salts were run to help characterize these compounds.

For the pentafluorothio compounds, the $\mathrm{SF}_{5}$ group is of major importance in explaining their NMR spectra. In the $\mathrm{SF}_{5}$ group, the fluorines are not all equivalent: the one axial fluorine (A) behaves differently from the four equatorial fluorines $\left(\mathrm{B}_{4}\right)$. In Pople notation, ${ }^{120}$ the $\mathrm{SF}_{5}$ groups is identified as an $\mathrm{AB}_{4}$ configuration. ${ }^{121-124}$ Because of the complex interactions between these two kinds of fluorine, the ${ }^{19} \mathrm{~F}$ NMR spectrum of the $\mathrm{SF}_{5}$ group shows a nine line pattern for the axial fluorine, and a twelve line pattern for the equatorial fluorines.122,124,125 Under the conditions for most of these spectra, the equatorial pattern appears as a doublet with fine structure. ${ }^{122}$ These $\mathrm{SF}_{5}$ fluorines influence the ${ }^{1} \mathrm{H}$, and ${ }^{13} \mathrm{C}$ NMR spectra through coupling. The equatorial fluorines are prominent in this regard, creating pentet patterns throughout the spectra.

Some comments on notation for $\mathrm{SF}_{5}$ compounds: " $\alpha$ " and " $\beta$ " refer to the carbon bonded to, and the carbon next to the carbon bonded to, the $\mathrm{SF}_{5}$ group respectively. These letters can therefore be used to denote the hydrogens or fluorines bonded to these carbons. From the pople notation for the configuration of the $\mathrm{SF}_{5}$ group, $\mathrm{AB}_{4}$, one can use "A" for "the axial fluorine" and "B" for "the equatorial 
fluorines" of the $\mathrm{SF}_{5}$ group. The subscripts "1" and "2" are sometimes needed when two atoms, like hydrogen or fluorine, bound to a single carbon are not magnetically equivalent.

For $\mathrm{SF}_{5} \mathrm{CH}_{2} \mathrm{CH}_{2} \mathrm{SO}_{2} \mathrm{OLi}$, there are two signal groups in the proton spectrum: a five-line group upfield, and a 13-line "rising sun" group downfield. The latter group is the more interesting of the two. There are two sets of alternating peaks: the larger peaks showing a $\mathrm{J}$ value of $8.1 \mathrm{~Hz}$ and the smaller peaks with $\mathrm{J}$ value $7.9 \mathrm{~Hz}$. It is clear from the large number of peaks that this $13-1$ ine $\alpha$ carbon pattern somehow arises from the coupling of the $\alpha$ carbon hydrogens with the $\beta$ carbon hydrogens and the $\mathrm{SF}_{5}$ equatorial fluorines, but a full explanation of this pattern remains problematic.

At first it was thought that the five line group might give clues to an explanation of the rising sun pattern. Willenbring has justly remarked that the bulky $\mathrm{SF}_{5}$ and $\mathrm{SO}_{3}$ groups will prefer to be in an anti configuration. ${ }^{88}$ This means that the methylene hydrogens will not be magnetically equivalent; in fact, the molecule will give an $\mathrm{AB}_{4} \mathrm{XX} \mathrm{X}^{\prime} \mathrm{Y} \mathrm{Y}^{\prime}$ pattern. ${ }^{126}$ This means that the $\alpha$ carbon subspectrum cannot be a simple one. ${ }^{123}$

Since there are no fluorines except in the $\mathrm{SF}_{5}$ group of $\mathrm{SF}_{5} \mathrm{CH}_{2} \mathrm{CH}_{2} \mathrm{SO}_{3} \mathrm{Li}$, the ${ }^{19} \mathrm{~F}$ spectrum shows simply the $\mathrm{SF}_{5}$ pattern described above. A high resolution spectrum for this compound yielded the resonance values for the nine-line 
axial fluorine pattern and the twelve line equatorial fluorine pattern.

The ${ }^{13} \mathrm{C}$ spectra reveal two carbons in the molecule, the $\alpha$ carbon signal downfield and the $\beta$ carbon signal upfield. The proton decoupled spectra show both of these signals as quintets, singlets split into five by the four $\mathrm{SF}_{5}$ equatorial fluorines. The magnitude of the coupling constant for the $\alpha$ carbon $(15.3 \mathrm{~Hz})$ is greater than it is for the $\beta$ carbon $(4.6 \mathrm{~Hz})$. For the proton-coupled spectrum, the $\beta$ carbon signal becomes a triplet of quintets due to the effect of the two $\beta$ hydrogens. The coupled spectrum of the $\alpha$ carbon is too weak and complex for analysis.

The proton spectrum of $\mathrm{SF}_{5} \mathrm{CH}_{2} \mathrm{CF}_{2} \mathrm{SO}_{2} \mathrm{OLi}$ shows a single pattern: a nine-ray rising sun. Willenbring et al. report that the equatorial sulfur fluorine-hydrogen coupling constant is almost exactly half of the $\beta$ carbon fluorinehydrogen coupling constant. ${ }^{87}$ This possibility would account for the number of peaks and approximate peak areas $(1-4-8-12-14-12-8-4-1)$ in this spectrum as well. For this spectrum $\mathrm{J}_{\mathrm{BH}_{\alpha}}=7.9 \mathrm{~Hz}, \mathrm{~J}_{\mathrm{CF}_{2} \mathrm{H}}=16.3 \mathrm{~Hz}$.

For the ${ }^{19} \mathrm{~F}$ spectrum, one finds that four, not two peaks with fine structure show up in the region for equatorial $\mathrm{SF}_{5}$ resonances. This effect does not appear in either the other two $\mathrm{SF}_{5}$ salts' spectra. The small set of doublets is probably due to an impurity, ${ }^{127}$ as the following evidence suggests. (1) The small set of doublets changes 
size relative to the large set of doublets. From the acid prepared by Willenbring to the sodium salt prepared by Willenbring to the lithium salt prepared here, the small set of doublets decreases in relative area. If the small set were a part of the same equatorial fluorine resonance as the large set, no such relative variation could occur. ${ }^{127}$ The number of resonances observed in the axial fluorine region was not the nine resonances usually seen for an $S_{5}$ compound, but twelve. This would make sense if the axial resonances for another $\mathrm{SF}_{5}$ containing compound were being observed along with those for $\mathrm{SF}_{5} \mathrm{CH}_{2} \mathrm{CF}_{2} \mathrm{SO}_{3} \mathrm{Li}$. (3) The equatorial fluorine subspectrum in an $\mathrm{SF}_{5}$ compound does not always appear as a pair of doublets with fine structure, as examination of examples taken from the literature will attest. ${ }^{121-123}$ Never, however, does one observe the entire equatorial resonance taking place over an interval of 400 $\mathrm{Hz}$, as would be the case of these four peaks were given by one compound. (4) The interval between peaks one and two is 4.5 little blocks on the spectrum grid, while the interval between peaks three and four is five blocks--close to being the same within experimental error. Five blocks is $141 \mathrm{~Hz}$; this is about the size of the coupling constant between axial and equatorial fluorines. This would be understandable if peaks one and two were produced by one $\mathrm{SF}_{5}$ containing compound, while peaks three and four were produced by another. 
There is one other signal in the $\mathrm{SF}_{5} \mathrm{CH}_{2} \mathrm{CF}_{2} \mathrm{SO}_{3} \mathrm{Li}$ fluorine spectrum, at $\phi=-112.0$; this is due to fluorines on the $\beta$ carbon. Although Willenbring et al. assign coupling constants for this subspectrum, ${ }^{87}$ such assignments cannot be made using first order principles alone and so do not appear here.

The ${ }^{13} \mathrm{C}$ spectra show two sets of peaks: the $\alpha$ carbon upfield and the $\beta$ carbon downfield. This is the reverse of the order for $\mathrm{SF}_{5} \mathrm{CH}_{2} \mathrm{CH}_{2} \mathrm{SO}_{3} \mathrm{Li}$, as Willenbring et al. observe for the corresponding acids. ${ }^{87}$ Presumably it is the fluorines present on the $\beta$ carbon that are responsible for this chemical shift reversal.

The $\alpha$ carbon signal for $\mathrm{SF}_{5} \mathrm{CH}_{2} \mathrm{CF}_{2} \mathrm{SO}_{3} \mathrm{Li}$ is split into a five line pattern by the four equatorial $\mathrm{SF}_{5}$ fluorines, into triplets of pentets by the two $\mathrm{CF}_{2}$ fluorines, and into triplets of triplets of pentets by its own hydrogens. The $\beta$ carbon signal is more interesting; it is a triplet in both the proton coupled and decoupled spectra. While willenbring et al. assign a coupling constant of $2.1 \mathrm{~Hz}$ for the $\mathrm{SF}_{5}$ equatorial fluorine- $\beta$ carbon splitting, ${ }^{87}$ the $\beta$ carbon peaks for the lithium salt show shoulders on the main peaks that could not be fully resolved. There is no sign of splitting from the hydrogens on the $\alpha$ carbon.

$\mathrm{SF}_{5} \mathrm{CHFCF}_{2} \mathrm{SO}_{2} \mathrm{OLi}$ can be predicted to give complex NMR spectra. The $\alpha$ carbon is asymmetric, causing the fluorines on the $\beta$ carbon to be non-equivalent. ${ }^{128}$ 
The single hydrogen in $\mathrm{SF}_{5} \mathrm{CHFCF}_{2} \mathrm{SO}_{2} \mathrm{Li}$ will have its proton NMR signal coupled with three kinds of fluorines. The four $\mathrm{SF}_{5}$ equatorial fluorines split this signal into a quintet; a $\beta$ carbon fluorine splits this into a doublet of quintets, and the $\alpha$ carbon fluorine splits this into a doublet of doublets of quintets.

It is noteworthy that one $\beta$ carbon fluorine couples with a $\alpha$ carbon hydrogen, while one does not, as willenbring et al. observe. Karplus found that the strength of coupling between vicinal carbon atoms depends on the dihedral angle between them. ${ }^{129}$ Presumably the same thing is true for fluorines as well as hydrogens. Because of the asymmetric $\alpha$ carbon, one $\beta$ carbon fluorine is so positioned on the average that it can couple with the $\alpha$ carbon hydrogen while the other $\beta$ carbon fluorine cannot.

The axial and equatorial fluorines of the $\mathrm{SF}_{5}$ group give the characteristic patterns noted at the beginning of this discussion.

The $\beta$ carbon fluorines call for comment. Since the $\alpha$ carbon is asymmetric, the $\beta$ carbon fluorines are not magnetically equivalent. They have very different chemical shifts $(-113.5$ and $-124.4 \mathrm{ppm})$, and split each other's signals into doublets. This much is clear; the patterns for the $\beta$ carbon fluorines and the $\alpha$ carbon fluorine as well are complex second order affairs.

As was true for $\mathrm{SF}_{5} \mathrm{CH}_{2} \mathrm{CF}_{2} \mathrm{SO}_{2} \mathrm{Li}$, the ${ }^{13} \mathrm{C}$ spectra of 
$\mathrm{SF}_{5} \mathrm{CHFCF}_{2} \mathrm{SO}_{2} \mathrm{OLi}$ has the $\alpha$ carbon subspectrum upfield and the $\beta$ carbon subspectrum downfield. However, in the case of $\mathrm{SF}_{5} \mathrm{CHFCF}_{2} \mathrm{SO}_{2} \mathrm{OLi}$, the two subspectra are closer together-presumably because of the fluorine on the $\alpha$ carbon.

The pair of non-equivalent $\beta$ carbon fluorines splits the $\beta$ carbon signal into a doublet of doublets, and the $\alpha$ carbon fluorine splits this into a doublet of doublets of doublets. Such is the symmetry of this splitting pattern that one cannot tell $J_{F_{\beta_{1}} c_{\beta}}$ from $J_{F_{\beta_{2}} c_{\beta}}$. The quality of the $\alpha$ carbon subspectrum is poor.

For the perfluoroalkane disulfonic acid dilithium salts, proton NMR spectra were run as a test for purity. Apart from water signals around $\delta=6$, (these spectra were run in deuterium oxide) no hydrogens were detected in these spectra. From NMR work one could state that all these compounds were perfluorinated.

The ${ }^{19} \mathrm{~F}$ NMR spectra should show a single peak for the one- and two-carbon disalts, and two $\mathrm{CF}_{2}$ resonances for the three-carbon, four-carbon, and four-carbon ether disalts. The $\mathrm{CF}_{2}$ resonances are in line with the literature values for the corresponding acids and potassium or sodium salts. ${ }^{82,83,89}$ The chemical shift values for fluorines $\mathrm{O}_{3} \mathrm{~S}-$ $\mathrm{CF}_{2} \mathrm{SO}_{3}$ are less negative than for fluorines $\mathrm{CF}_{2}-\mathrm{CF}_{2}-\mathrm{SO}_{3}$ which are in turn less negative than for fluorines $\mathrm{CF}_{2} \mathrm{CF}_{2}-\mathrm{CF}_{2}$. It is also worth noting that the resonance values for the fluorines on these lithium salts are between the literature 
values for the corresponding acids and the corresponding potassium salts.

Now the resonances for the one- and two-carbon perfluoroalkyl disulfonic acid disalts ought to be singlets because of symmetry, but this should not be true for the three- and four-carbon disalts. For the latter disalts, the fluorines on carbons bonded to sulfur and the fluorines on carbons not bonded to sulfur will be chemically but not magnetically equivalent. (Compare the hydrogens in 1-bromo2-chloroethane. ${ }^{130}$ ) An AA'MM' spectrum should be expected ${ }^{127}$, a non-first order arrangement. Accordingly the two $\mathrm{CF}_{2}$ resonances for the three-and four-carbon disalts are found on higher resolution to be unresolved multiplets, as was found to be the case for $\mathrm{CF}_{2}\left(\mathrm{CF}_{2} \mathrm{SO}_{2} \mathrm{~F}\right)_{2} \cdot{ }^{131}$

The singlets found for the ether salt $\mathrm{O}\left(\mathrm{CF}_{2} \mathrm{CF}_{2} \mathrm{SO}_{3} \mathrm{Li}\right)_{2}$ remain singlets even at high resolution. The couplings between the $\mathrm{OCF}_{2}$ fluorines and the $\mathrm{CF}_{2} \mathrm{~S}$ fluorines in $\mathrm{Ca}\left[\mathrm{CF}_{2}\left(\mathrm{OCF}_{2} \mathrm{CF}_{2} \mathrm{SO}_{3}\right)_{2}\right]$ and $\mathrm{Na}_{2}\left[\mathrm{CH}_{2}\left(\mathrm{OCF}_{2} \mathrm{CF}_{2} \mathrm{SO}_{3}\right)_{2}\right]$ were not resolved and were estimated to be less than $1.5 \mathrm{~Hz} .{ }^{132}$ Although the ${ }^{19} \mathrm{~F}$ spectrum might appear as though it came from another compound due to the lack of coupling, the ${ }^{13} \mathrm{C}$ spectrum (see below) gives unambiguous evidence that $\mathrm{OCF}_{2}$ and $\mathrm{SCF}_{2}$ are present.

The ${ }^{13} \mathrm{C}$ spectra for the perfluoroalkyl disulfonic acid salts show one kind of carbon for the one- and two-carbon compounds. The three-carbon compound spectra give evidence 
for two kinds of carbon, while the four-carbon compound spectra show second order effects. The chemical shifts agree with the values reported for the two-, three- and four-carbon acids and salts. ${ }^{83}, 133$

The one-carbon salt gives a triplet: the carbon signal is split into triplet by its own pair of fluorines. The two-carbon salt yields a triplet of triplets. The two carbons are magnetically equivalent. The signals for each carbon is split into triplets by its neighbor's two fluorines, and these triplets are further split into triplets of triplets by its own fluorines.

The three-carbon salt gives a triplet of triplets and a triplet of quintets; the one subspectrum comes from the two outer carbons, while the other subspectrum comes from the inner carbon. The two fluorines on the central carbon split the signal from the end carbons into a triplet; the four fluorines on the end carbons split the signal from the central carbon into a quintet. However each of these three carbons has two fluorines of its own, and the ${ }^{1} J_{C F}$ values are larger than the ${ }^{2} J_{C F}$ values: the triplet and quintet become a triplet of triplets and a triplet of quintets.

A triplet of triplets and a triplet of pentets seems to appear in the ${ }^{13} \mathrm{C}$ spectrum for the four carbon salt, too--at least at first glance. The subspectrum for the inner carbons is indeed a triplet of pentets, just as for the three-carbon salt. The triplet of triplets combination is 
not so perfect, though; the outer peaks for each of these sets of triplets are split into doublets. There is no satisfactory way to explain this detail using first order principles. ${ }^{133}$

The ${ }^{13} \mathrm{C}$ spectrum for the acid of the ether salt, $\mathrm{O}\left(\mathrm{CF}_{2} \mathrm{CF}_{2} \mathrm{SO}_{2} \mathrm{OH}\right)_{2}$, was reported to consist of two sets of triplets of triplets, one of the $\mathrm{OCF}_{2}$ carbon, one for the $\mathrm{CF}_{2} \mathrm{~S}$ carbon. ${ }^{134} \mathrm{~A}$ higher resolution spectrum run on the lithium salt revealed a second order spectrum. The fluorines in the $\mathrm{OCF}_{2} \mathrm{CF}_{2} \mathrm{~S}$ structure of the ether salt are no more magnetically equivalent than the hydrogens in $\mathrm{BrCH}_{2} \mathrm{CH}_{2} \mathrm{Cl} .{ }^{130}$ Since this is so, we cannot expect these fluorines to give anything but imperfect sets of triplets on coupling with the carbon.

A sample of the polymer of $\widehat{\mathrm{OCH}_{2}-\mathrm{CH}}-\mathrm{CH}_{2}-\mathrm{O}-\mathrm{CF}_{2} \mathrm{CF}_{2} \mathrm{SO}_{3} \mathrm{Li}$ was likewise submitted to ${ }^{1} \mathrm{H}$ and ${ }^{13} \mathrm{C}$ NMR analysis. In the proton spectrum, there is a pair of broad unresolved resonance centered near $\delta=3.7$ and 4.2 . This spectrum is therefore like the spectrum of the polymer without lithium. ${ }^{90}$

The ${ }^{19} \mathrm{~F}$ spectrum of the polymer salt gives resonances at -85 and $-116.5 \mathrm{ppm}$; this is close to the $-85.6,-112.2$ ppm reported for the unlithiated polymer. ${ }^{90}$ These peaks appear to be broad singlets, but no attempt was made to employ high resolution on them to prove the point.

The ${ }^{13} \mathrm{C}$ spectrum of the polymer salt also showed two broad unresolved subspectra: one from 59.8-71.3 for the 
carbons with hydrogens (cf. the $\mathrm{O}-\mathrm{CH}_{2}$ carbon in diethyl ether, for which $\delta=67.4 \mathrm{ppm})^{128}$, and the other 110.1-115.4 for the carbons with fluorines. The fluorinated subspectrum is much like the ${ }^{13} \mathrm{C}$ spectrum for the ether salt. This is as it should be, since both have $\mathrm{OCF}_{2} \mathrm{CF}_{2} \mathrm{SO}_{3} \mathrm{Li}$ groups.

\section{NUCLEAR MAGNETIC RESONANCE DATA}

The shift of the axial fluorine is measured from line six of the nine line pattern; it is also the sixth line from the left. ${ }^{88}$ The shift for the equatorial fluorines is measured from the middle of the integration. ${ }^{88}$

All chemical shifts are measured in ppm; all coupling constants are measured in Hertz. 
TABLE XXVIII

$\mathrm{SF}_{5} \mathrm{CH}_{2} \mathrm{CH}_{2} \mathrm{SO}_{3} \mathrm{LI}$

\begin{tabular}{||l|l||}
\hline \hline${ }^{1} \mathrm{H}:$ & \\
\hline$\delta_{\alpha}=4.12$ & $\delta_{\beta}=3.47$ \\
\hline Integral Ratios $\alpha: \beta=1.00: 1.02$ \\
\hline${ }^{19} \mathrm{~F}:$ & \\
\hline Axial Pattern & Equatorial Pattern \\
\hline$\phi=79.71$ & $\phi=62.88$ \\
\hline 81.22 & 62.98 \\
\hline 81.68 & 63.08 \\
\hline 82.97 & 63.17 \\
\hline 83.12 & 64.71 \\
\hline 83.43 & 64.80 \\
\hline 84.75 & 64.87 \\
\hline 85.03 & \\
\hline 86.52 & \\
\hline$\phi_{\mathrm{A}}=83.0$ & 64.94 \\
\hline${ }^{13} \mathrm{C}:$ & 65.04 \\
\hline$\delta_{\alpha}=67.2$ & \\
\hline $\mathrm{J}_{\mathrm{BC}}=15.2$ & $\delta_{\beta}=48.2$ \\
\hline $\mathrm{J}_{\mathrm{BC}}=4.5$ & \\
\hline
\end{tabular}


TABLE XXIX

$\mathrm{SF}_{5} \mathrm{CH}_{2} \mathrm{CF}_{2} \mathrm{SO}_{3} \mathrm{Li}$

\begin{tabular}{|c|c|}
\hline \multicolumn{2}{|l|}{${ }^{1} \mathrm{H}:$} \\
\hline \multicolumn{2}{|l|}{$\delta=4.61$} \\
\hline $\mathrm{J}_{\mathrm{BC}_{\alpha}}=7.9$ & $\mathrm{~J}_{\mathrm{HCF}_{2}}=16.3$ \\
\hline \multicolumn{2}{|l|}{${ }^{19} \mathrm{~F}:$} \\
\hline$\phi_{\mathrm{A}}=80.8$ & $\phi_{\mathrm{F}_{\beta}}=-110.8$ \\
\hline \multicolumn{2}{|c|}{ Integral Ratio $\left(\mathrm{A}: \mathrm{B}: \mathrm{F}_{\beta}\right)=1.2: 4.0: 1.8$} \\
\hline \multicolumn{2}{|l|}{${ }^{13} \mathrm{C}:$} \\
\hline$\delta_{\alpha}=67.2$ & $\delta_{\beta}=116.9$ \\
\hline $\mathrm{J}_{\mathrm{BC} \alpha}=17.4$ & $\mathrm{~J}_{\mathrm{HC}_{\alpha}}=144.24$ \\
\hline $\mathrm{J}_{\mathrm{BC}_{\beta}}=0$ & $\mathrm{~J}_{\mathrm{CF}_{2} \mathrm{C}_{\beta}}=281.0$ \\
\hline
\end{tabular}


TABLE XXX

$\mathrm{SF}_{5} \mathrm{CHFCF}_{2} \mathrm{SO}_{3} \mathrm{Li}$

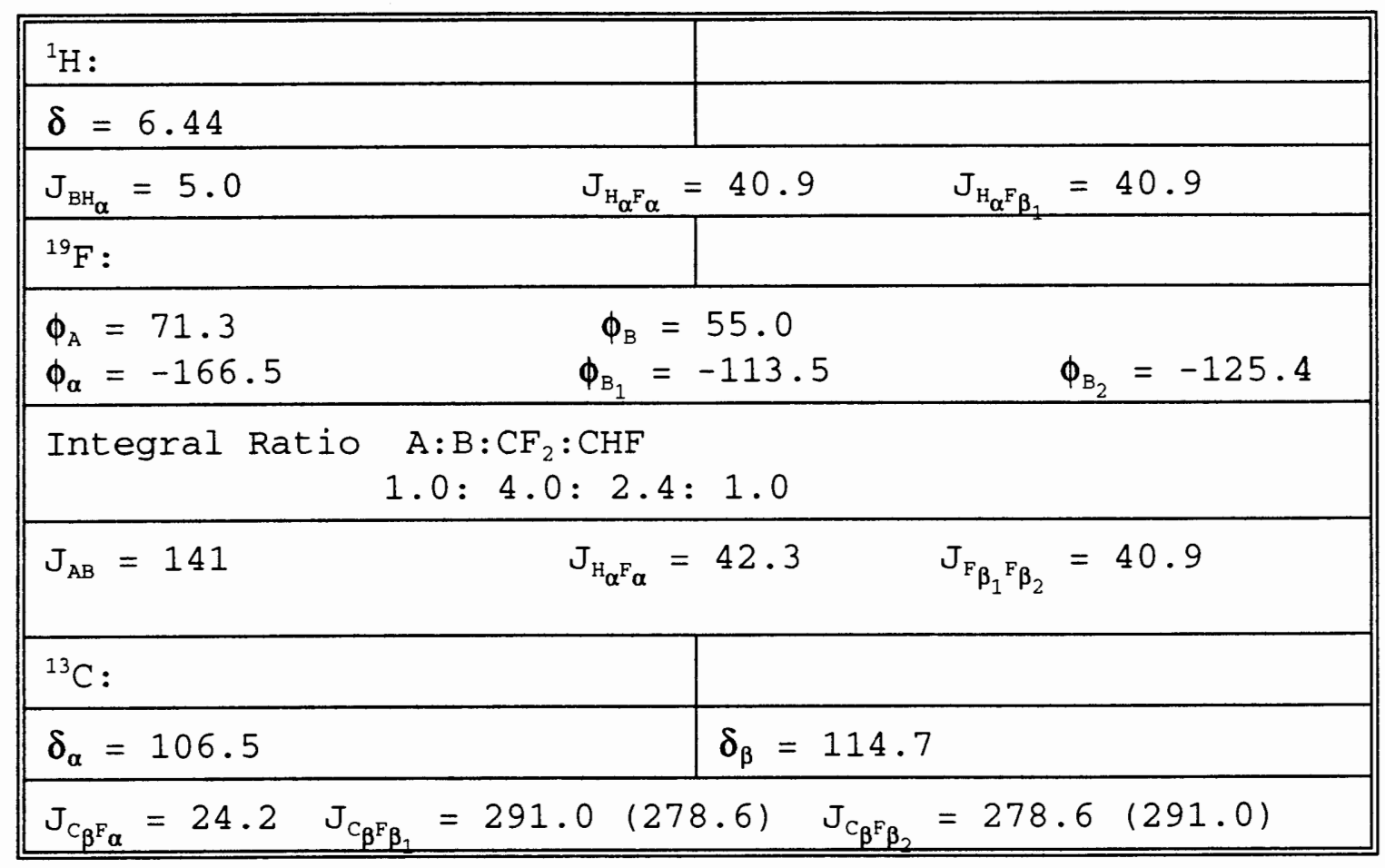

TABLE XXXI

${ }^{19} \mathrm{~F}--$ PERFLUOROALKYL DISULFONIC ACID DILITHIUM SALTS

$\mathrm{LiOSO}_{2}\left(\mathrm{CF}_{2}\right)_{\mathrm{n}} \mathrm{SO}_{2} \mathrm{OLi}$

\begin{tabular}{||l|l|l|l||}
\hline \hline$n$ & $\begin{array}{l}\phi \text { Outer Carbons } \\
(\mathrm{ppm})\end{array}$ & $\begin{array}{l}\phi \text { Inner Carbons } \\
(\mathrm{ppm})\end{array}$ & $\begin{array}{l}\text { Integral Ratio } \\
\text { Outer: Inner }\end{array}$ \\
\hline 1 & -107 & & \\
\hline 2 & -114.6 & & \\
\hline 3 & -114.3 & -120.3 & $1.00: 1.89$ \\
\hline 4 & -115.3 & -122 & $1.00: 0.98$ \\
\hline
\end{tabular}


$\mathrm{LiOSO}_{2}\left(\mathrm{CF}_{2}\right)_{2} \mathrm{O}\left(\mathrm{CF}_{2}\right)_{2} \mathrm{SO}_{2} \mathrm{OLi}$

\begin{tabular}{||l|l|l||}
\hline \hline $\begin{array}{l}\phi \mathrm{CF}_{2} \mathrm{~S} \text { Carbons } \\
(\mathrm{ppm})\end{array}$ & $\begin{array}{l}\phi \mathrm{CF}_{2} \mathrm{O} \text { Carbons } \\
(\mathrm{ppm})\end{array}$ & $\begin{array}{l}\text { Integral Ratio } \\
\mathrm{CF}_{2} \mathrm{~S}: \mathrm{CF}_{2} \mathrm{O}\end{array}$ \\
\hline-83.3 & -120.0 & $1.00: 1.01$ \\
\hline
\end{tabular}

TABLE XXXII

${ }^{13} \mathrm{C}$ PERFLUOROALKYL DISULFONIC ACID DILITHIUM SALTS

$\mathrm{LiOSO}_{2}\left(\mathrm{CF}_{2}\right)_{\mathrm{n}} \mathrm{SO}_{2} \mathrm{OLi}$

\begin{tabular}{||l|l|l|l|l||}
\hline $\mathrm{n}$ & $\begin{array}{l}\delta^{\mathrm{a}} \text { Outer Carbons } \\
(\mathrm{ppm})\end{array}$ & $\begin{array}{l}\delta^{\mathrm{b}} \text { Inner } \\
\text { Carbons }(\mathrm{ppm})\end{array}$ & ${ }^{1} \mathrm{~J}_{\mathrm{CF}}$ & ${ }^{2} \mathrm{~J}_{\mathrm{CF}}$ \\
\hline 1 & 119.0 & & 310 & \\
\hline 2 & 115.5 & & 288 & 37.0 \\
\hline 3 & 115.6 & & 292 & 36.5 \\
\hline 3 & & 112.7 & 264 & 32.3 \\
\hline 4 & 115.2 & & 291 & 34 \\
\hline 4 & & 112.7 & 269 & 32 \\
\hline
\end{tabular}

$\mathrm{LiOSO}_{2}\left(\mathrm{CF}_{2}\right)_{2} \mathrm{O}\left(\mathrm{CF}_{2}\right)_{2} \mathrm{SO}_{2} \mathrm{OLi}$

\begin{tabular}{|l|l|l|l||}
\hline$\delta \mathrm{CF}_{2} \mathrm{~S}$ Carbons & $\delta \mathrm{CF}_{2} \mathrm{O}$ Carbons & ${ }^{1} \mathrm{~J}_{\mathrm{CF}}$ & ${ }^{2} \mathrm{~J}_{\mathrm{CF}}$ \\
\hline 116.4 & & 290 & 31.8 \\
\hline & 111.6 & 290 & 37.2 \\
\hline
\end{tabular}

a. Band center of multiplets; outer carbons attached to sulfur.

b. Band center of multiplets; inner carbons attached to carbon. 
CHAPTER V

OTHER PATHWAYS

A number of other reactions were run in order to find easier and more productive pathways for preparing lithium salts of fluoroacids. Pathways for the production of dry lithium sulfonate salts were especially desirable. The salts of lithium are notorious for their hygroscopicity-lithium chloride will dissolve in the puddle of water it attracts from the air--and sulfonate salts are no exception. Weeks of drying on the vacuum line with constant stirring were required for these salts--and sometimes even this was not enough. Therefore productions of the salts in nonaqueous media were explored.

A general method for the synthesis of water free metal carboxylates from acid halides and metal trimethylsilanolates ${ }^{135}$ was developed in the laboratory of $\mathrm{M}$. Armand into a preparation of water-free sulfonates from sulfonyl fluorides and potassium trimethylsilanolate. ${ }^{136}$ A switch from potassium to lithium yields the lithium sulfonates desired:

$\mathrm{R}_{\mathrm{f}} \mathrm{SO}_{2} \mathrm{~F}+\left(\mathrm{CH}_{3}\right)_{3} \mathrm{SiOLi} \longrightarrow \mathrm{R}_{\mathrm{f}} \mathrm{SO}_{2} \mathrm{OLi}+\left(\mathrm{CH}_{3}\right)_{3} \mathrm{SiF}$

The preparation attempt involved the use of 
perfluorooctane sulfonyl fluoride. A commercial grade of this compound, 3M Fluorad FX-8, was here employed, an NMR estimate of its purity amounting to about $95 \% .{ }^{116}$ A $0.49 \mathrm{~g}$ (0.0051 moles) portion of lithium trimethylsilanolate (Aldrich, 97\%) was reacted with $3.80 \mathrm{~g}$ of Fluorad, the sulfonyl fluoride being in excess (0.0751 moles). A $50 \mathrm{ml}$ round bottomed flask was charged with the reactants, and about $25 \mathrm{ml}$ of Molecular Sieve 4A-dried tetrahydrofuran (Aldrich, 99+8). The flask was heated on a hot plate in a glove bag. The yellow trimethylsilanolate color slowly disappeared. Evaporation of the THF proceeded slowly; the product was evidently very soluble in it. Petroleum ether (grade and manufacture unknown) was then added, and a light yellow precipitate formed. Yield: $30.6 \%$.

This good preparative method would have required fine tuning to give large yields. Rapid evaporation would be necessary to minimize decomposition of moisture sensitive materials in the leaky glove bag. Our eight-carbon product may have been more soluble in petroleum ether than the compounds produced in high yield in the laboratory of Prof. Armand.

An attempt to prepare difficultly soluble silver sulfonates was made, since many silver compounds such as the carboxylates ${ }^{137}$ are sparingly soluble. The silver salts of $\mathrm{R}_{\mathrm{f}} \mathrm{SO}_{3} \mathrm{H}$ or $\mathrm{HOSO}_{2}\left(\mathrm{CF}_{2}\right)_{\mathrm{n}} \mathrm{SO}_{2} \mathrm{OH}$ could then be treated with $\mathrm{LiCl}$, giving the corresponding lithium sulfonates. 
A $1.62 \mathrm{~g}$ sample of $\left(\mathrm{CF}_{2} \mathrm{SO}_{2} \mathrm{OK}\right)_{2}(0.0479$ moles; $3 \mathrm{M} \mathrm{L}-5433)$ and $1.71 \mathrm{~g} \mathrm{AgNO}_{3}(0.0101$ moles; Mallinckrodt AR grade) was dissolved in water; very little precipitate was observed. Methanol was added, but not much more precipitated. The weight of the wet precipitate was $0.09 \mathrm{~g}$.

This disappointment taught that poor solubility for a silver sulfonate is not a given; silver triflate is very soluble. ${ }^{138}$ Discovering the right set of concentration and solvent composition conditions to maximize the solubility of the reactants and minimize the solubility of the product might take a great deal of time.

A synthetic route to lithium sulfonates by way of silver and trimethylsilyl compounds was contemplated:

$$
\begin{gathered}
2 \mathrm{HOSO}_{2} \mathrm{R}_{\mathrm{f}}+\mathrm{Ag}_{2} \mathrm{O} \longrightarrow \mathrm{H}_{2} \mathrm{O}+2 \mathrm{AgOSO}_{2} \mathrm{R}_{\mathrm{f}} \\
\mathrm{AgOSO}_{2} \mathrm{R}_{\mathrm{f}}+\left(\mathrm{CH}_{3}\right)_{3} \mathrm{SiCl} \longrightarrow \mathrm{AgCl} \downarrow+\left(\mathrm{CH}_{3}\right)_{3} \mathrm{SiOSO}_{2} \mathrm{R}_{\mathrm{f}} \\
\left(\mathrm{CH}_{3}\right)_{3} \mathrm{SiOSO}_{2} \mathrm{R}_{\mathrm{f}}+\mathrm{LiCl} \longrightarrow\left(\mathrm{CH}_{3}\right)_{3} \mathrm{SiCl} \uparrow+\mathrm{LiOSO}_{2} \mathrm{R}_{\mathrm{f}}
\end{gathered}
$$

where $R_{f}$ here is some fluorine containing group. Similar equations can be written for disulfonic acids.

Preparations like (23) have been employed with success before; silver trifluoromethane sulfonate has been prepared this way. ${ }^{139,140}$ Examples of (24) are likewise extant; trimethylsilyl trifluoromethanesulfonate was first prepared in this way. ${ }^{141}$

It is reaction (25) that is new; ${ }^{117}$ some comment is necessary. Here we are trying to get a hard silicon atom ${ }^{142}$ (to use Pearson's hard and soft acid and base nomenclature) 
to exchange a harder trifluoromethane sulfonate ion for a softer chloride ion. Extensive reaction would not be expected, since hard-hard combinations would be preferred. It is true, however, that cleavage of the silicon-chlorine bond using heteroatom containing nucleophiles--the reverse of the process desired--is an equilibrium process. ${ }^{142}$ In this case the desired process is an unfavorable equilibrium-but an equilibrium can be influenced by volatility of one of the products. ${ }^{142}$ Since trimethylsilyl chloride is more volatile than either of the reactants, it follows that reaction may be forced to completion by removing the $\left(\mathrm{CH}_{3}\right)_{3} \mathrm{SiCl}$. It is worth trying to see if heating will work to make this reaction succeed.

Because this third reaction was the only one of the three that was not a standard preparation, several trials of it were made. Lithium chloride (Aldrich, 99.99+8) was reacted with trimethylsilyl triflate (Aldrich, 96\%). In the first test, methanol was employed as a solvent. This methanol was not completely dry, and the triflate reacted with the residue of water in the methanol. So running the reaction in a solvent was given up, and the use of a reaction vessel instead of a round-bottomed flask was adopted.

In the second test, $0.78 \mathrm{~g}$ LiCl $(0.018$ moles $)$ was placed in a $100 \mathrm{ml}$ reaction vessel with $4.79 \mathrm{~g}(0.0216$ moles) $\left(\mathrm{CH}_{3}\right)_{3} \mathrm{SiOSO}_{2} \mathrm{CF}_{3}$. The weighing took place in a dry 
box, and the closed reaction vessel was then removed and attached to the vacuum line. A $200 \mathrm{~mm} \mathrm{Hg}$ pressure of nitrogen was used to purge the line, and a $50 \mathrm{~mm} \mathrm{Hg}$ pressure of nitrogen was maintained in the line during reaction. the reaction vessel was allowed to stir at room temperature, and was connected to the line through a nitrogen cold trap.

Although this arrangement was intended to provide a way to condense trimethylsilyl chloride as produced, so driving the reaction to completion, $1.51 \mathrm{~g}$ of weight was found in the reaction vessel after evacuating the vessel of volatile contents. This weight corresponded to a 34.98 yield for seven days' reaction.

The volatile materials were then transferred back into the reaction vessel, and the reaction was continued. This time there were two changes: (1) the vessel was to be heated to $40^{\circ} \mathrm{C}$ and (2) the trap was not used. At first, temperature control was poor, and the temperature rose at times to $100^{\circ} \mathrm{C}$. After four days of reaction, the weight of solids in the vessel was $2.50 \mathrm{~g}$ corresponding to an $82.3 \%$ yield. The vessel was then charged with $1.38 \mathrm{~g}$ of trimethylsilyl triflate, and another three days of heating to $44-48^{\circ} \mathrm{C}$ gave a $2.63 \mathrm{~g}$ weight of solids--an $88.5 \%$ yield. Because the gain in yield was so small, it was decided to discontinue reaction. This sample had a melting point of $363^{\circ} \mathrm{C}$, a figure that is likely high because of the presence of $\mathrm{LiCl}$ (m.p. $\left.610^{\circ} \mathrm{C}\right)^{143}$ - - cf. m.p. $\mathrm{CF}_{3} \mathrm{SO}_{2} \mathrm{ONa}: 251^{\circ} \mathrm{C} \cdot{ }^{143}$ 
A third trial of this reaction was undertaken; $0.62 \mathrm{~g}$ LiCl (0.015 moles) was stirred with $3.81 \mathrm{~g}\left(\mathrm{CH}_{3}\right)_{3} \mathrm{SiOSO}_{2} \mathrm{CF}_{3}$ (0.0171 moles) at $44-47^{\circ} \mathrm{C}$ for nine days to give $56.7 \%$ yield. Another six days of heating at $62-67^{\circ} \mathrm{C}$ gave a $68.7 \%$ yield $(1.76 \mathrm{~g})$. An 89.88 sample of this mixture, $1.58 \mathrm{~g}$, was then stirred with $1.06 \mathrm{~g}$ trimethylsilyl triflate (0.00477 moles) in a round-bottomed flask with condenser and drying tube. After heating to $90^{\circ} \mathrm{C}$ for over 20 hours, it was found that conversion to lithium triflate was essentially complete $(102.48$ yield; $2.10 \mathrm{~g})$. However, a sample of the remaining powder gave a solution that yielded a precipitate with silver nitrate. In spite of the apparent weight, some chloride remained in the product.

In the fourth and final trial of the lithium chloridetrimethylsilyl triflate reaction, the equilibrium nature of this interaction was considered. A sample of lithium chloride (Aldrich, 99.99+8) thought to weigh $0.75 \mathrm{~g}(0.018$ moles) was stirred with an excess, $20.08 \mathrm{~g}$ (0.09034 moles), of trimethylsilyl triflate (Aldrich, 99\%) in a reaction vessel at $72^{\circ} \mathrm{C}$ for two weeks. Then the reaction vessel, cooled to about $-15^{\circ} \mathrm{C}$ using an ethylene glycol-liquid nitrogen slush bath, was connected to the vacuum line through a liquid nitrogen--cooled cold trap. The trimethylsilyl chloride produced was condensed into a trap cooled to $-196^{\circ} \mathrm{C}$; only a small portion of the much less volatile trimethylsilyl triflate was removed. This 
procedure was repeated after $5,5,4$, and 4 days until the weight changes in the reaction vessel and in the cold trap were negligible. The remainder of the trimethylsilyl triflate was then pumped off to give a final weight for the reaction vessel contents of $3.03 \mathrm{~g}$, which would correspond to 0.0194 moles of pure lithium triflate--a 1088 yield. A sample of the reaction vessel's contents gave no precipitate with silver nitrate solution.

The product sample obtained did indeed show the characteristics of lithium triflate. The ${ }^{19} \mathrm{~F}$ nuclear magnetic resonance spectrum showed only a singlet at $\phi=-$ 79.8. This is a spectral region where fluorines on carbons bonded to sulfonate groups appear; compare the $\phi=-83.3$ for the analogous fluorines on $\mathrm{O}\left(\mathrm{CF}_{2} \mathrm{CF}_{2} \mathrm{SO}_{3} \mathrm{Li}\right)_{2}$.

The infrared spectrum likewise shows characteristics of a fluorinated sulfonate. Using the criteria for infrared spectra employed above in Chapter 4, the $1234 \mathrm{~cm}^{-1}$ band may be assigned to the $\mathrm{CF}_{2}$ stretch, the $1267 \mathrm{~cm}^{-1}$ band to the $\mathrm{SO}_{3}$ asymmetric stretch and the $1094 \mathrm{~cm}^{-1}$ band to the $\mathrm{SO}_{3}$ symmetric stretch. 
CHAPTER VI

\section{RESULTS AND DISCUSSION}

\section{PREPARATION}

The main method for the preparation of lithium sulfonates consisted of (1) the use of ion exchange resin to make an acid from its corresponding salt, and (2) the neutralization of that acid with lithium hydroxide using a $\mathrm{pH}$ meter. The ion exchange method is simple, rapid, quantitative, cheap and non-destructive of sample. The neutralization process was tricky at times because the endpoint could be overshot easily--as the descriptions of syntheses bear witness. This problem could have been overcome by first converting the Amberlite IR-120 to the lithium form with lithium chloride, then passing an aqueous solution of the corresponding metal salt through this lithiated resin.

The barium salt-lithium sulfate procedure for making difluoromethane disulfonic acid dilithium salt proceeded smoothly, for the most part. However the industrial product barium salt was not entirely water soluble, and removal of the particles was difficult. The digestion of barium sulfate to give particles large enough for filtration can also be difficult. Perhaps the ion exchange procedure 
should have been used in this case as well.

Although these aqueous preparations are comparatively readily performed, the long periods of drying required to render the samples suitable for polymer electrolyte work are a drawback.

The lithium trimethylsilanolate sulfonyl fluoride preparation gave a disappointing 30.68 yield. Dr. Armand's student got 858 yields using this kind of reaction ${ }^{136}$, and the yields for the carboxyl analogues using the related reaction of alkali metal trimethyl silanolates on acid halides, etc., were uniformly higher (51-988). ${ }^{135}$ The glove bag employed in this preparation was leaky, allowing moisture to react with the trimethylsilanolate. The round bottomed flask was not shaped properly for rapid evaporation; it took many days to reduce the solvent level sufficiently to induce precipitation. The eight carbon product may have been more soluble in the petroleum ether used as precipitant than Dr. Armand's student's products were. Solvent and equipment changes would have been necessary to adopt this sound synthetic method to present conditions.

The lithium chloride-trimethylsilyl triflate reaction shows promise, pointing towards a general method for the preparation of lithium alkyl sulfonates. By taking advantage of the equilibrium nature of this reaction and removing the trimethylsilyl chloride product repeatedly, it 
was possible to obtain a chloride-free salt product. The technique will have to be refined before it can be considered a practical general method, however: a procedure that produces only one mole of salt for every five moles of trimethylsilyl alkyl sulfonate starting material cannot be considered a procedure of choice.

The polymer salt preparation would probably have been simplified if greater knowledge of the polymer had been available. Three preparations of polymer salt were attempted on the assumption that polymerization does not affect the reaction of the sulfonyl fluoride moiety with lithium hydroxide. Only the batch made from a polymer sample that was not placed on the vacuum line to remove volatile oligomers gave a near neutral product with lithium hydroxide ${ }^{144}$; this preparation was reported above. This fact would seem to indicate that the structure of the high molecular weight species are such that the sulfonyl fluoride moiety is not always available for reaction. The hydroxyl ions could not reach some of the sulfonyl fluorides for reaction and consequently made the resulting solution alkaline.

Greater knowledge of the relative solubilities of the polymer and the polymer salt in various solvents might have allowed the construction of a different and more effective synthetic method for the preparation.

For each of the lithium sulfonate salts, ignorance of 
the temperature of decomposition made synthetic work more difficult. Heated reaction mixtures frequently proceed to completion faster, and heating aids the expulsion of water from a drying product. But the lithium ion is small and thus easily polarized (Fajan's Rules) ${ }^{17}$ so its salts have a greater tendency towards breakdown. ${ }^{117}$ An infrared spectrum of $\left(\mathrm{CF}_{2} \mathrm{SO}_{2} \mathrm{OLi}\right)_{2}$ dried at $68^{\circ} \mathrm{C}$ showed a number of peaks not present in the spectrum of the same salt dried at room temperature. This was a sign that heating should be used with caution.

TABLE XXXIII

DECOMPOSITION POINT OF LITHIUM SULFONATES

\begin{tabular}{||c|c|}
\hline \multicolumn{1}{|c|}{ Compound } & Decomposition Point $\left({ }^{\circ} \mathrm{C}\right)$ \\
\hline \hline $\mathrm{SF}_{5} \mathrm{CH}_{2} \mathrm{CH}_{2} \mathrm{SO}_{2} \mathrm{OLi}$ & 2900 \\
\hline $\mathrm{SF}_{5} \mathrm{CH}_{2} \mathrm{CF}_{2} \mathrm{SO}_{2} \mathrm{OLi}$ & 258 \\
\hline $\mathrm{SF}_{5} \mathrm{CHFCF}_{2} \mathrm{SO}_{2} \mathrm{OLi}$ & 231 \\
\hline $\mathrm{CF}_{2}\left(\mathrm{SO}_{2} \mathrm{OLi}\right)_{2}$ & 224 \\
\hline$\left(\mathrm{CF}_{2} \mathrm{SO}_{2} \mathrm{OLi}\right)_{2}$ & 264 \\
\hline $\mathrm{CF}_{2}\left(\mathrm{CF}_{2} \mathrm{SO}_{2} \mathrm{OLi}\right)_{2}$ & 295 \\
\hline$\left(\mathrm{CF}_{2} \mathrm{CF}_{2} \mathrm{SO}_{2} \mathrm{OLi}\right)_{2}$ & 312 \\
\hline
\end{tabular}


TABLE XXXIV

SOLUBILITY OF PERFLUOROALKYL DISULFONIC ACID DILITHIUM SALTS

\begin{tabular}{||l|c|}
\hline \multicolumn{1}{|c|}{ Compounds } & $\begin{array}{c}\text { Aqueous Solubility } \\
\left(\mathrm{g} / \mathrm{L} ; 25^{\circ} \mathrm{C}\right)\end{array}$ \\
\hline \hline $\mathrm{CF}_{2}\left(\mathrm{SO}_{2} \mathrm{OLi}\right)_{2}$ & 56 \\
\hline$\left(\mathrm{CF}_{2} \mathrm{SO}_{2} \mathrm{OLi}\right)_{2}$ & 80 \\
\hline $\mathrm{CF}_{2}\left(\mathrm{CF}_{2} \mathrm{SO}_{2} \mathrm{OLi}\right)_{2}$ & 32 \\
\hline$\left(\mathrm{CF}_{2} \mathrm{CF}_{2} \mathrm{SO}_{2} \mathrm{OLi}\right)_{2}$ & 55 \\
\hline$\left(\mathrm{CF}_{2} \mathrm{CF}_{2} \mathrm{CF}_{2} \mathrm{SO}_{2} \mathrm{OLi}\right)_{2}$ & 5.6 \\
\hline
\end{tabular}

TABLE XXXV

CONDUCTIVITY OF LITHIUM SULFONATES IN PEO

( 8 MOLES OF PEO OXYGEN: 1 MOLE OF SULFONATE LITHIUM)

\begin{tabular}{||c|c|c||}
\hline \multicolumn{1}{|c|}{ Compound } & $\begin{array}{c}\text { Conductivity } \\
\left(\Omega^{-1} \mathrm{Cm}^{-1}, 60^{\circ} \mathrm{C}\right)\end{array}$ & $\begin{array}{c}\text { Conductivity } \\
\left(\Omega^{-1} \mathrm{Cm}^{-1}, 100^{\circ} \mathrm{C}\right)\end{array}$ \\
\hline \hline$\left(\mathrm{CF}_{2} \mathrm{SO}_{2} \mathrm{OLi}\right)_{2}$ & $3 \times 10^{-8}$ & $2 \times 10^{-7}$ \\
\hline $\mathrm{CF}_{2}\left(\mathrm{CF}_{2} \mathrm{SO}_{2} \mathrm{OLi}\right)_{2}$ & $3 \times 10^{-8}$ & $8 \times 10^{-7}$ \\
\hline$\left(\mathrm{CF}_{2} \mathrm{CF}_{2} \mathrm{SO}_{2} \mathrm{OLi}\right)_{2}$ & $4 \times 10^{-7}$ & $3 \times 10^{-6}$ \\
\hline $\mathrm{O}\left(\mathrm{CF}_{2} \mathrm{CF}_{2} \mathrm{SO}_{2} \mathrm{OLi}\right)_{2}$ & $6 \times 10^{-7}$ & $5 \times 10^{-6}$ \\
\hline $\mathrm{SF}_{5} \mathrm{CHFSO}_{2} \mathrm{Li}$ & $2 \times 10^{-4}$ & $1 \times 10^{-3}$ \\
\hline $\mathrm{SF}_{5} \mathrm{CF}_{2} \mathrm{SO}_{2} \mathrm{Li}$ & $1 \times 10^{-4}$ & $3 \times 10^{-4}$ \\
\hline
\end{tabular}

PROPERTIES OF THE LITHIUM COMPOUNDS

Stability

None of these lithium sulfonates melts on heating; each sinters and discolors. Since discoloration is not a process 
with clear beginning or end, it is difficult to assign decomposition temperatures to these compounds. The temperature at which a compound shows a clear sign of turning brown or gray was the temperature chosen for reporting in Table XXXIII.

It is evident that the $\mathrm{SF}_{5}$ compounds decompose at lower temperatures at the alkyl portion of the compound becomes increasingly fluorinated. It apparently becomes easier to split off $\mathrm{HF}$, with subsequent energetically favorable formation of $\mathrm{LiF}^{117}$, as these compounds become more fluorinated.

It is also evident that the perfluoroalkyl disalts decompose at higher temperatures as the number of alkyl carbons increases. This is expected behavior for most homologous alkyl series.

Willenbring reports that $\mathrm{SF}_{5} \mathrm{CH}_{2} \mathrm{HC}_{2} \mathrm{SO}_{2} \mathrm{ONa}$ melts at $260^{\circ} \mathrm{C}$ and $\mathrm{SF}_{5} \mathrm{CH}_{2} \mathrm{CF}_{2} \mathrm{SO}_{2} \mathrm{ONa}$ at $279^{\circ} \mathrm{C} .{ }^{88}$ Although the trend reported seems to be opposite to the trend for the corresponding lithium salt decomposition temperatures, it is difficult to make any assessment without the decomposition temperature for $\mathrm{SF}_{5} \mathrm{CHFCF}_{2} \mathrm{SO}_{2} \mathrm{ONa}$.

\section{Solubility}

The solubilities of these compounds were not rigorously or systematically determined; many trials were made on tiny amounts for the purpose of determining the right solvent for NMR work. The sulfonates are polar compounds, and dissolve 
in polar solvents. Water was the best solvent of all those tried for both the $\mathrm{SF}_{5}$ compounds and the perfluoroalkyl compounds. The solubilities of the $\mathrm{SF}_{5}$ compounds were not determined because of the amount of each salt prepared was small. The solubilities of the perfluoroalkyl disalts were determined roughly (see discussion-preparation of Lithium Sulfonates for details); the results appear in Table XXXIV. Two trends are evident in these solubilities: solubility decreases as molecular weight increases, and (2) the $2 \mathrm{n}$ homologues are more soluble than the $2 \mathrm{n}-1$ homologues. The first of these trends is common in homologous series, but there is no ready explanation of the second--if indeed these rough solubility figures are not in error.

Next to water, these compounds dissolve better in methanol than in any other solvent tried. The $S_{5}$ compounds were more soluble in methanol than the perfluoroalkyl disalts. The two carbon disalt was soluble in dioxane to the extent of less than $5 \mathrm{~g} / \mathrm{L}$, and in dimethyl sulfoxide and trifluoroacetic acid to the extent of less than $1 \%$. The six carbon disalt was soluble in tetrahydrofuran to the extent of less than $2 \mathrm{~g} / \mathrm{L}$.

\section{Conductivity}

Dr. Michael Lerner and his research group at Oregon State University measured the conductivities of several of these salts in poly(ethylene oxide) in a ratio of eight oxygens of the PEO to one lithium of the salt. ${ }^{93}$ Table XXXV 
gives these conductivities at $60^{\circ} \mathrm{C}$ and $100^{\circ} \mathrm{C}$. For the four salts measured, the two-, and three-, and four-carbon disalt and the ether salt $\mathrm{O}\left(\mathrm{CF}_{2} \mathrm{CF}_{2} \mathrm{SO}_{2} \mathrm{OLi}\right)_{2}$, the ether salt has the highest conductivity at both temperatures. However, none of these disalts compares favorably with lithium triflate, $\mathrm{CF}_{3} \mathrm{SO}_{2} \mathrm{OLi}$, determined by Robitaille and Fauteux to have conductivity $10^{-5} \Omega^{-1} \mathrm{~cm}^{-1}$ at $60^{\circ} \mathrm{C}$ for the same $8: 1$ PEO to salt ratio. ${ }^{72}$ It appears that sulfonic acid disalts do not have the superior conductivity that Bannister, Davies, Ward and McIntyre predicted. ${ }^{74}$

However, the conductivities of the two one carbon $\mathrm{SF}_{5}$ salts $\mathrm{SF}_{5} \mathrm{CF}_{2} \mathrm{SO}_{2} \mathrm{OLi}$ and $\mathrm{SF}_{5} \mathrm{CHFSO}_{2} \mathrm{OLi}$, prepared by Nicolas $\mathrm{N}$. Hamel, are 2-3 orders of magnitude higher--comparable with $\mathrm{N}\left(\mathrm{CF}_{3} \mathrm{SO}_{2}\right)_{2} \mathrm{Li}$ and $\mathrm{C}\left(\mathrm{CF}_{3} \mathrm{SO}_{2}\right)_{3} \mathrm{Li}$ (see Table I). These salts are now eligible for testing with real lithium anodes and lithium-intercalating cathodes to see if they survive the rigors of the hundreds of charging and discharging cycles that are a part of normal battery life.

\section{CONCLUSIONS}

Since a good research project raises more questions than it settles, it is appropriate here to ask the following questions as good topics for future research:

(1) What happened to cause the prediction of Bannister, Davies, Ward and McIntyre ${ }^{74}$ that perfluoroalkyl disulfonic acid dilithium salts should have superior 
conductivity to fail?

(2) Nicolas N. Hamel's $\mathrm{SF}_{5} \mathrm{CHFSO}_{2} \mathrm{OLi}$ conducts better than his $\mathrm{SF}_{5} \mathrm{CF}_{2} \mathrm{SO}_{2} \mathrm{OLi}$. Usually the presence of electronreleasing hydrogen in a salt of this kind is sufficient to give it an inferior conductivity to a salt that is saturated with electron-withdrawing fluorines. Why does the hydrogen containing salt have a better conductivity here?

(3) What makes these two $\mathrm{SF}_{5}$ salts better conductors than the perfluoroalkyl disulfonic acid disalts?

(4) Of the four disalts tested, the salt with the ether linkage turned out to be a better conductor than the straight chain salts. Why? 


\section{REFERENCES}

1. Bruno Scrosati in Modern Batteries, Vincent, C.A. with F. Bonino, M. Lazzari and B. Scrosati Eds.; Edward Arnold: London, 1984; Chapter 7 .

2. Duward F. Shriver and Gregory C. Farrington, Chemical and Engineering News 63 , (20) 42 (1985).

3. Alan Hooper, Contemporary Physics 19, No. 2, 147 (1978).

4. W. van Gool, Annual Review of Materials Science 4, 311 (1974)

5. P. McGeehin and A. Hooper, Journal of Materials Science 12, 1 (1977).

6. D.H. Whitmore, Journal of Crystal Growth 39, 160 (1977).

7. G.C. Farrington in Solid state Batteries, C.A.C. Sequeira and A. Hooper Eds., Martinus Nijhoff, Dordrecht Boston Lancaster (1985) p. 29.

8. G.C. Farrington and J.L Briant, Science 204, 1371 (1979).

9. J. B. Bates, J.-C. Wang and N.J. Dudney, Physics Today 35, (7) 46 (1982).

10. B.B. Owens and G.R. Argue, Science 157, 308 (1967).

11. S. Geller, Science 157, 310 (1967).

12. S. Geller, Accounts of Chemical Research 11, 87 (1979).

13. J.N. Bradley and P.D. Greene, Transactions of the Faraday Society 63,2516 (1967).

14. G.C. Farrington in Solid state Batteries, C.A.C. Sequeira and A. Hooper, Eds., Martinus Nijhoff, Dordrecht Boston Lancaster 1985 p. 19.

15. J.B. Goodenough in Encyclopedia of Materials Science and Engineering, Michael Bever, Ed.; Pergamon-MIT, Cambridge, Vol VI, 4778 (1986). 
16. Y.Y. Yao and J.T. Kummer, Journal of Inorganic and Nuclear Chemistry $\underline{29}, 2453$ (1967) as cited in references (9), (18).

17. J.E. Huheey, Inorganic Chemistry 3rd Ed., HarperCollins, New York, 1983.

18. K.P. Jagannathan, S.K. Tiku, H.S. Ray, A. Ghosh, E.C. Subbarao in Solid Electrolytes and Their Applications, E.C. Subbarao, Ed., Plenum, New York and London, 1980.

19. W. Baukal in From Electrocatalysis to Fuel Cells, G. Sandstede Ed., Battell Seattle Research Center and University of Washington Press, Seattle and London, 1972 .

20. B.B. Owens in Advances In Electrochemistry and Electrochemical Engineering, P. Delahay and C.W. Tobias Eds., Wiley Interscience, 1971, Vol. 8.

21. Fast Ion Transport In Solids: Solid State Batteries and Devices, W. Van Gool, Ed., North Holland, 1973.

22. B.B. Owens, P.M. Skarstad and D.F. Untereker in Handbook of Batteries and Fuel Cells D. Linden Ed., McGraw-Hill, New York, 1984 .

23. M. Gauthier, A. Belanger, B. Kapfer, G. Vassort, M. Armand in Polymer Electrolyte Reviews-2, J.R. McCallum and C.A. Vincent Eds., Elsevier Applied Science, London New York, 1989.

24. Günther Holzäpfel in Encyclopedia of Physical Science and Technology, Academic Press, 1987, Vol. 13 p. 39.

25. M.G. Kanatzidis, Chemical and Engineering News 68 , 36 (1990).

26. F.M. Gray, Solid Polymer Electrolytes VCH Publishers, New York, 1991.

27. T. Oi, Annual Reviews of Materials Science 16, 185 $(1986)$.

28. C.A. Vincent, Progress in Solid state Chemistry 17, 145 (1987).

29. D.F. Shriver, B.L. Papke, M.A. Ratner, R. Dupon, T. Wong, M. Brodwin, Solid State Ionics 5 , 83 (1981).

30. D.E. Fenton, J.M. Parker and P.V. Wright, Polymer 14, 589 (1973), cited in reference (28). 
31. P.V. Wright, British Polymer Journal I, 319 (1975) cited in reference (28).

32. M.B. Armand in polymer Electrolyte Reviews-1, J.R. McCallum and C.A. Vincent Eds., Elsevier Applied, Science London and New York, 1987.

33. Y. Takahashi and H. Tadokoro, Macromolecules $\underline{6}, 672$ (1973) cited in reference (28).

34. B.L. Papke, M.A. Ratner \& D.F. Shriver, Journal of the Electrochemical Society 129, 1434 (1982)

35. B.L. Papke, M.A. Ratner \& D.F. Shriver, Journal of the Physical Chemistry of Solids $\underline{42}, 493$ (1981).

36. M.A. Ratner In Polymer Electrolyte Reviews-1 J.R. McCallum and C.A. Vincent Eds., Elsevier Applied Science London and New York 1987.

37. P.V. Wright in Polymer Electrolyte Reviews-2 J.R. McCallum and C.A. Vincent Eds., Elsevier Applied Science, London and New York, 1989.

38. G.C. Farrington and R.G. Linford in Polymer Electrolyte Reviews-2 J.R. MCCallum and C.A. Vincent Eds., Elsevier Applied Science, London and New York, 1989.

39. M. Minier, C. Berthier, W. Gorecki, Journal de Physique $\underline{45}, 739$ (1984).

40. S. Pantaloni, S. Passerini, F. Croce, B. Scrosati, A. Roggero, M. Andrei, Electrochimica Acta 34, 635 (1989)

41. F.M. Gray in Polymer Electrolyte Reviews-1 J.R. McCallum and C.A. Vincent Eds., Elsevier Applied Science, London and New York, 1987.

42. J.M.G. Cowie in Polymer Electrolyte Reviews-1 J.R. McCallum and C.A. Vincent Eds., Elsevier Applied Science, London and New York, 1987.

43. C. Booth, C.V. Nicholas, D.J. Wilson in Polymer Electrolyte Reviews-2 J.R. McCallum and C.A. Vincent, Eds., Elsevier Applied Science, London and New York, 1989 .

44. C. Wang, Q. Liu, Q. Cao, Q. Meng, I. Yang, Solid State Ionics 53-56 (Part 2), 1106 (1992); Chem Abstr. 1992 $117(22): 223739 \mathrm{~h}$ 
45. K. Akashiro, T. Nagai, H. Horiie, T. Manabe, Japanese Patent 63136409 A2 8 Jun 1988 Showa; Chem Abstr. 1988 $109(16): 132065 d$.

46. K. Akashiro, T. Nagai, H. Horiie, T. Manabe, Japanese Patent 63136407 A2 8 Jun 1988 Showa Chem Abstr. 1988 $109(16)$ : $132067 f$.

47. E. Tsuchida, H. Ohno, K. Tsunemi, N. Kobayashi, Solid State Ionics 11 (3) 227 (1983) Chem Abstr. 1983 $100(14)$ : $112807 \mathrm{~h}$.

48. M. Watanabe and N. Ogata In polymer Electrolyte Reviews 1 J.R. McCallum and C.A. Vincent Eds., Elsevier Applied Science, London and New York, 1987.

49. K.M. Abraham, M. Alamgir, R.D. Moulton, Proceedings of the 34th Annual Power Sources Symposium, p. 81.; Chem Abstr. $1990116(14): 132659 \mathrm{v}$.

50. S. A. Dobrowski, J.E. McIntyre, I.M. Ward and G.R. Davies, British Patent 2216132 A1 4 Oct 1989; Chem Abstr. 1989 112(16): 140792r.

51. D.G.H. Ballard, P. Cheshire, J. Brzeworski, European Patent 260847 A1 24 Mar. 1988; Chem Abstr. 1988 109(6): $40767 f$.

52. R. Huq, G.C. Farington, R. Koksbang, P.E. Tonder, Solid State Ionics $\underline{57}(3-4), 277$ (1992), Chem Abstr. 1992 $118(4): 29054 \mathrm{~m}$.

53. M.L. Kaplan, E.A. Reitman, R.J. Cava, Polymer 30, 504 (1989); Chem Abstr. 1989 110(26):232419m.

54. N. Kobayashi, N. Kubo, R. Hirohashi, Electrochimica Acta 37(9), 1515 (1992); Chem Abstr. 1992 $117(16): 161716$ n.

55. L.A. Dominey, T.J. Blakley, V.R. Koch, Proceedings of the Twenty-fifth IECEC Meeting, August 16, 1990; Reno, Nevada.

56. P.G. Bruce and F. Krok, Solid State Ionics $\underline{36}, 171$ (1989).

57. M.B. Armand in Solid State Batteries, C.A.C. Sequeira and A. Hooper Eds., Martinus Nijhoff, Dordrecht Boston Lancaster, (1985).

58. D.A. Winn, J.M. Schemilt and B.C.H. Steele, Materials Research Bulletin 11, 559 (1976). 
59. D.W. Murphy and P.A. Christian, Science 205, (4407) 651 (1979).

60. M.S. Wittingham, Science 192, 1126 (1976).

61. D. Deroo, Second International Symposium on Polymer Electrolytes, B. Scrosati Ed., Elsevier, London 433 (1989).

62. P. Baudry, M.A. Aegerter, D. Deroo, B. Valla, Journal of Electrochemical Society 138, 460 (1991).

63. O. Bohnke and C. Bohnke, Journal of the Electrochemical Society 138, 3612 (1991).

64. M. S. Wilson and S. Gottesfeld, Journal of the Electrochemical Society, 139, L28 (1992).

65. T.E. Springer, T.A. Zawodzinski, S. Gottesfeld, Journal of Electrochemical Society 138, 2334 (1991).

66. M.W. Verbrugge and R.F. Hill, Journal of the Electrochemical Society 137, 3770 (1990).

67. A. Bettelheim, A. Raven, M. Polak and D. Ozer, Journal of the Electrochemical Society 139, 132 (1992).

68. D. Linden, Handbook of Batteries and Fuel Cells, McGraw Hill, New York (1984)

69. J.R. MCCallum and C.A. Vincent in Polymer Electrolyte Reviews-1 J.R. McCallum and C.A. Vincent Eds., Elsevier Applied Science, London and New York, 1987.

70. M.B. Armand, J.M. Chabagno, M.. Duclot in Fast Ion Transport In Solids, P.M. Vashishta, J.N. Mundy, G.K. Shenoy Eds., North Holland, (1979).

71. P.R. Sorensen, and T. Jacobsen, Electrochimica Acta 27, (12) 1671 (1982).

72. C.D. Robitaille \& D. Fauteux, Journal of Electrochemical Society 133, (2) 315 (1986).

73. A. Vallee, S. Besner, J. Prud'homme, Electrochimica Acta 37(9), 1579 (1992).

74. D.J. Bannister, G.R. Davies, I.M. Ward, J.E. McIntyre, Polymer Communications 25, 1291 (1984)

75. W.A. Sheppard, Journal of the American Chemical Society 85, 1314 (1963). 
76. D. Benrabah, D. Baril, J.-Y Sanchez, M.B. Armand, G.L. Gard, Journal of the Chemical Society-Faraday Transactions 89, (2) 355 (1993).

77. S. Sylla, J.-Y. Sanchez, M.B. Armand, Electrochimica Acta $37(9), 1699$ (1992).

78. J. Burdon and J.C. Tatlow in Advances in Fluorine Chemistry, M. Stacy, J.C. Tatlow and A.B. Sharpe Eds., Butterworths, London Vol. 1 (1960).

79. Nagase, S. Fluorine Chemistry Reviews, P. Tarrant Ed., Dekker, New York, , Vol. 1 (1967).

80. T. Gramstad and R. N. Haszeldine, Journal of the Chemcial Society 1956, 2640.

81. E.J.M. O'Sullivan, F.W. Klink, C.C. Liu, E.B. Yeager, Journal of Electrochemical Society 132 (10), 2424 (1985) .

82. H. Saffarian, P. Ross, F. Behr, G. Gard, Journal of Electrochemical Society $139(9), 2391$ (1992).

83. R. Herkelmann and P. Sartori, Journal of Fluorine Chemistry 노, 299 (1989).

84. J.M. Canich, M.M. Ludvig, G.I. Gard and J.M. Shreeve, Inorganic Chemistry $\underline{23}$ (19), 4403 (1984).

85. G.L. Gard, A. Waterfeld, R. Mews, J. Mohtasham and R. Winter, Inorganic Chemistry 29, 4588 (1990).

86. R.J. Terjeson, J. Mohtasham and G.L. Gard, Inorganic Chemistry 27, 2916 (1988).

87. R.J. Willenbring, J. Mohtasham, R. Winter, G.L. Gard, Canadian Journal of Chemistry 67, 2037 (1989).

88. R.J. Willenbring Master's thesis, Portland state University (1987).

89. W. Cen, Z-X Dong, T.-J. Huang, D.Su and J. M. Shreeve, Inorganic Chemistry 27, 1376 (1988).

90. N.N. Hamel, G.A. Russell\& G.L. Gard, Journal of Fluorine Chemistry, in press.

91. L.-F. Chen, J. Mohtasham and G. L. Gard, Journal of Fluorine Chemistry 46,39 (1990). 
92. D.F. Shriver and M.A. Drezdzon, The Manipulation of Air Sensitive Compounds Wiley Interscience, New York (1986), p. 57 .

93. Michael Lerner, private communication to G.L. Gard.

94. J.C. Hansen and P.M. Savu, European Patent O 444822 A1 Feb 21, 1991.

95. In-house work.

96. R. Paterson, An Introduction to Ion Exchange Heyden and Sons, Ltd., London, Sadtler Research Laboratories, Philadelphia (1970).

97. F. Helffrich, Ion Exchange McGraw-Hill, New York (1962).

98. K. Dorfner, Ion Exchangers: Prperties and Applications (A. Fe'-Coers, ed.) Ann Arbor Science, Ann Arbor, Michigan (1972).

99. 1985 Annual Book of ASTM Standards Section 11 water and Environmental Technology, Volume 11.02 Water (II), ASTM, Philadelphia (1985); D-2187 (E).

100. N.N. Greenwood and A. Earnshaw, Chemistry of the Elements, Pergamon, Oxford (1984).

101. M. Barber, R.S. Bordoli, G.J. Elliott, R.D. Sedgwick and A.N. Tyler, Analytical Chemistry $\underline{54}$, (4) $645 \mathrm{~A}$ (1982).

102. M. Barber, R.S. Bordoli, R.D. Sedgwick and A.N. Tyler, Nature 293, 270 (1981).

103. F.A. White and G.M. Hood, Mass Spectrometry:

Applications In Science and Enqineering, Wiley Interscience, New York, (1986).

104. P.A. Lyon, K.B. Tomer and M.L. Gross, Analytical Chemistry 57, 2984 (1985).

105. Chang-Hwa Ryu, Private communication.

106. C. Larsen, U. Anthoni, P.H. Nielsen and C. Christophersen, Organic Mass Spectroscopy 22, 117 (1987).

107. E. Schröder, H Münster, H. Budzikiewicz, Organic Mass Spectrometry 21, 707 (1986). 
108. F.W. Röllgen and H.-R. Schulten, Zeitschirft Für Naturforschung 30a, 1685 (1975).

109. D.N. Heller, C. Fenselaw, J. Yergey, R.J. Cotter \& D. Larkin, Analytical Chemistry 56,2274 (1984).

110. L.H. Cross, G. Cushing and H.L. Roberts, Spectrochimica Acta 17, 334 (1961).

111. R.A. DeMarco and W.B. Fox, Journal of Fluorine Chemistry 12, 137 (1978).

112. J.K. Brown and K.J. Morgan in Advances In Fluorine Chemistry 4, M. Stacey, J.C. Tatlow and A.G. Sharpe, Eds., Butterworth, Washington, (1965).

113. D.G. Weiblen in Fluorine Chemistry II J.H. Simons, Ed., Academic Press, New York, 1954.

114. L.J. Bellamy, The Infrared Spectra of Complex Molecules Chapman and Hall, London, John Wiley, New York, 1975.

115. G. Socrates, Infrared Characteristic Group Frequencies wiley-Interscience, Chichester, 1980.

116. Nicolas N. Hamel, private communication.

117. G.L. Gard, private communication.

118. J.K. Brown and K.J. Morgan in Advances in Fluorine Chemistry 4, M. Stacey, J.C. Tatlow and A.G. Sharpe Eds., Butterworth, Washington (1965).

119. Spectrum taken by N. Robert Holcomb.

120. J.A. Pople, W.G. Schneider and H.J. Bernstein, High Resolution Nuclear Magnetic Resonance McGraw-Hill, New York, 1959.

121. R.K. Harris and K.J. Packer, Journal of the Chemical Society 1961, 4736 .

122. C.I. Merrill, S.M. Williamson, G.H. Cady and D.F. Eggers Jr., Inorganic Chemistry 1, (2) 215 (1962).

123. N. Boden, J.W. Emsley, J. Feeney \& L.H. Sutcliffe, Transactions of the Faraday Society 59,620 (1962).

124. M.G. Barlow, R.R. Dean and J. Lee, Transactions of Faraday Society (2) $\underline{62}, 321$ (1969). 
125. N. Muller, P.C. Lauterbur \& G.F. Svatos, Journal of the American Chemical Society 79, 1043 (1957).

126. Notice that reference 123 above identifies $\mathrm{ClCH}_{2} \mathrm{CH}_{2} \mathrm{SF}_{5}$ as an $\mathrm{AB}_{4} \mathrm{XX} \mathrm{XY}^{\prime} \mathrm{Y}$ ' pattern.

127. Dr. David H. Peyton, private communication.

128. R.M. Silverstein, G.C. Bassler and T.C. Morrill, Spectrometric Identification of Organic Compounds 5 th ed., John Wiley, New York, 1991.

129. H.S. Gutowsky, M. Karplus \& D.M. Grant, Journal of Chemical Physics 31, (5) 1278 (1959).

130. A. Ault, Journal of Chemical Education 51, (I1) 729 (1974).

131. E. Hollitzer and P. Sartori, Journal of Fluorine Chemistry 35,329 (1987).

132. G.L. Gard, N.N. Hamel, J. Mohtasham, A. Waterfeld, and R. Mews, Journal of Fluorine Chemistry $\underline{5}, 313$ (1991).

133. Dale Braden, private communication.

134. J. Mohtasham, G.L. Gard, Portland State University, J.P. Canselier, Ecole Nationale Superieure D'Ingenieurs de Genie Chimique, "C-13 NMR Studies of Fluorosultones and Fluorosulfonic Acids", 46th Regional ACS Meeting, La Grande, Oregon, June 1991.

135. E. D. Laganis \& B.L. Chenard, Tetrahedron Letters 25 , (51) 5831 (1984).

136. Michel Armand to Gary L. Gard, private communication (March 5, 1991).

137. N.R. Thompson "Silver", Vol. 3 of Comprehensive Inorganic Chemistry, J. C. Bailar, H.J. Emeléus, R. Nyholm, A.F. Trotman-Dickenson, Eds., Pergamon Press, Oxford 1973 .

138. R.N. Haszeldine and J.M. Kidd, Journal of Chemical Society, 1954, 4228 .

139. T. Gramstad and R.N. Haszeldine, Journal of the Chemical Society 1956, 173.

140. G.M. Whitesides and F.D. Gutowski, Journal of Organic Chemistry 41, 2882 (1976). 
141. M. Schmeißer, P. Sartori \& B. Lippsmeier, Chemische Berichte 103, 868 (1970).

142. E.W. Colvin, Silicon In Organic Synthesis, Butterworths, London, (1981).

143. Dictionary of Inorganic Compounds, J.E. Macintyre Executive Ed., Chapman and Hall, London, 1992.

144. N. Robert Holcomb, private communication. 
APPENDIX

FIGURES 


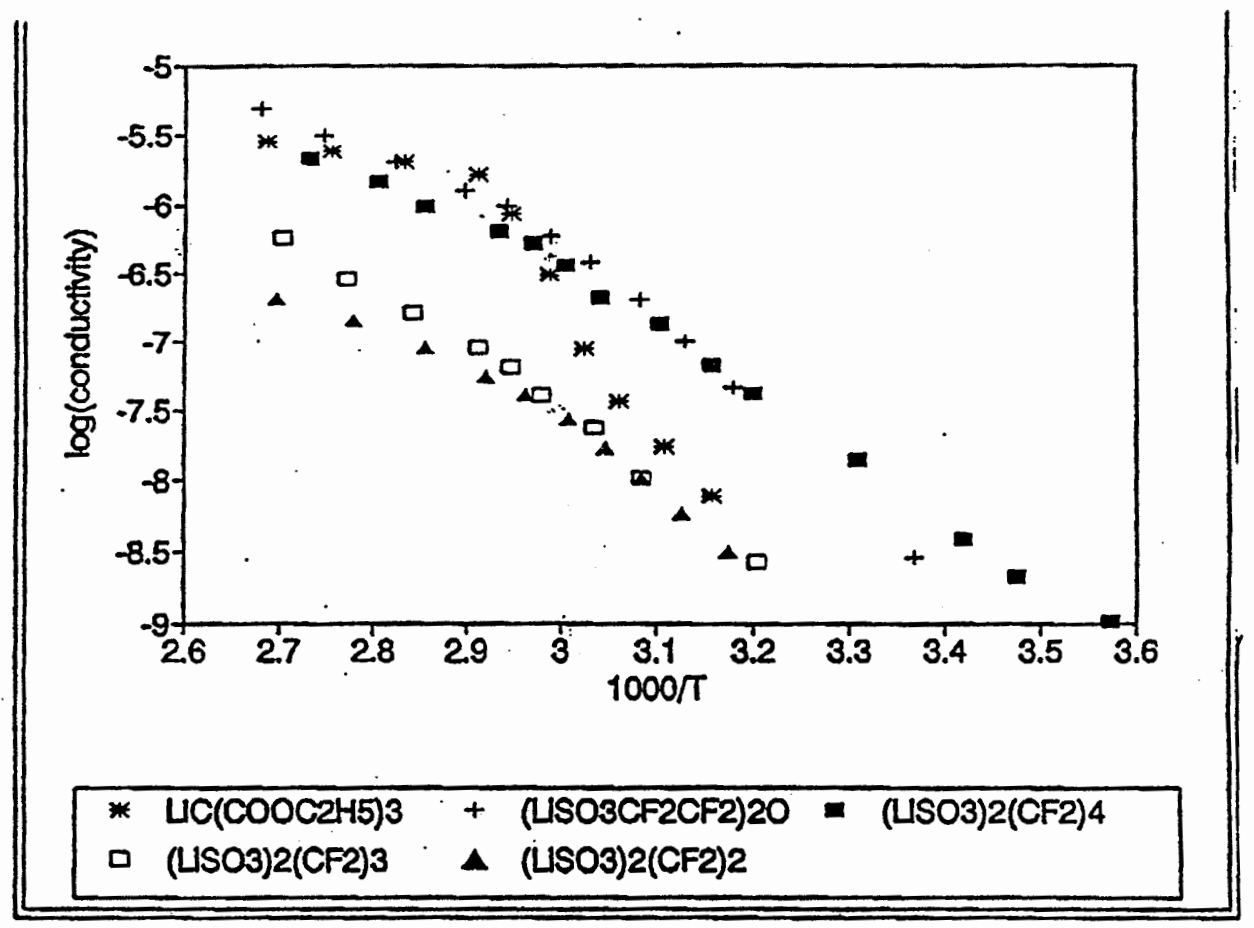

FIGURE 1: Plot of Log (Conductivity. $\Omega \cdot \mathrm{cm}$ ) vs. $1000 / \mathrm{T}$ (in K) for Perfluoroalkane Disulfonic Acid Dilithium Salts 


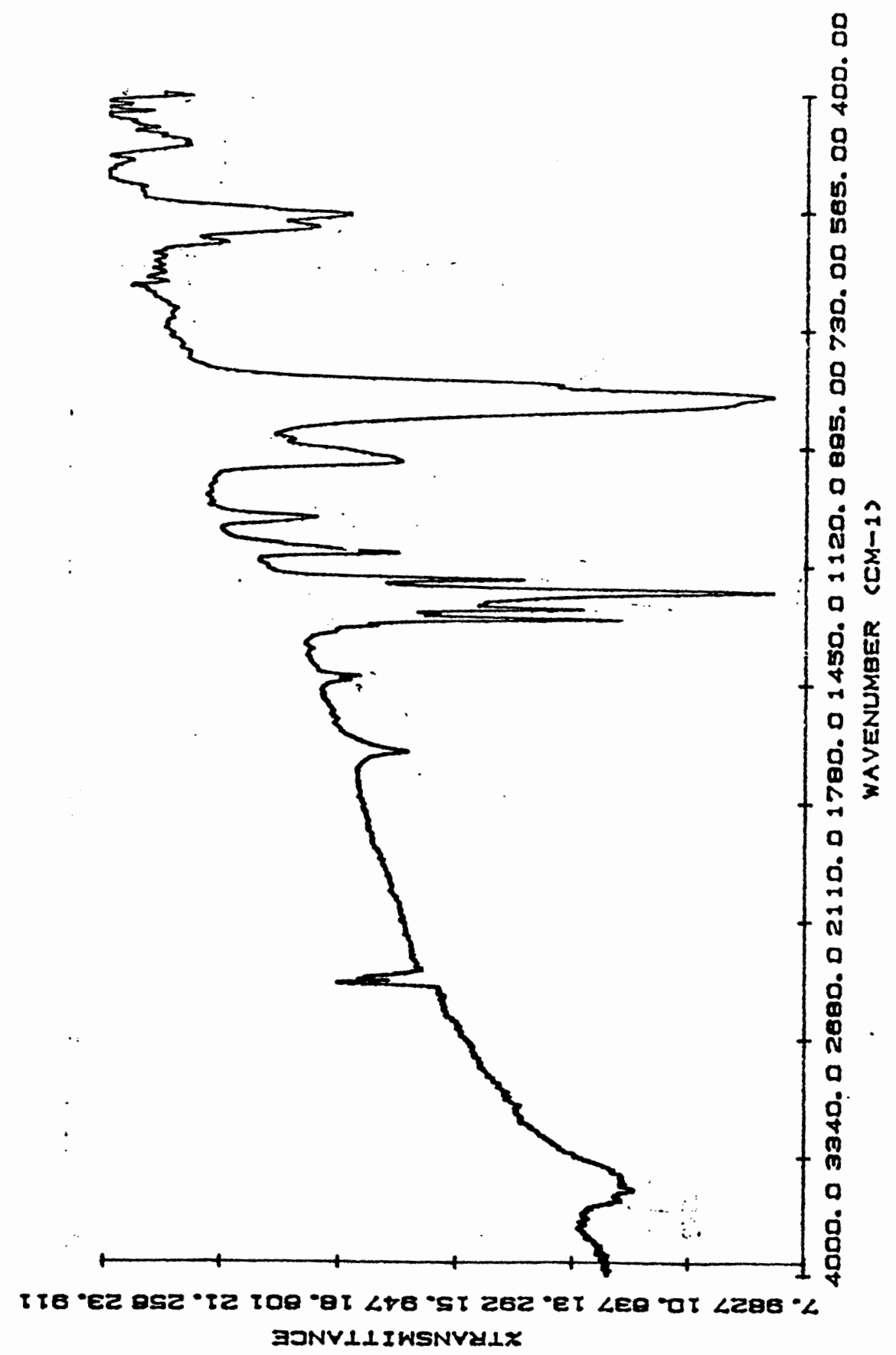

FIGURE 2: Infrared Spectrum of $\mathrm{SF}_{5} \mathrm{CH}_{2} \mathrm{CH}_{2} \mathrm{SO}_{3} \mathrm{Li}$ 


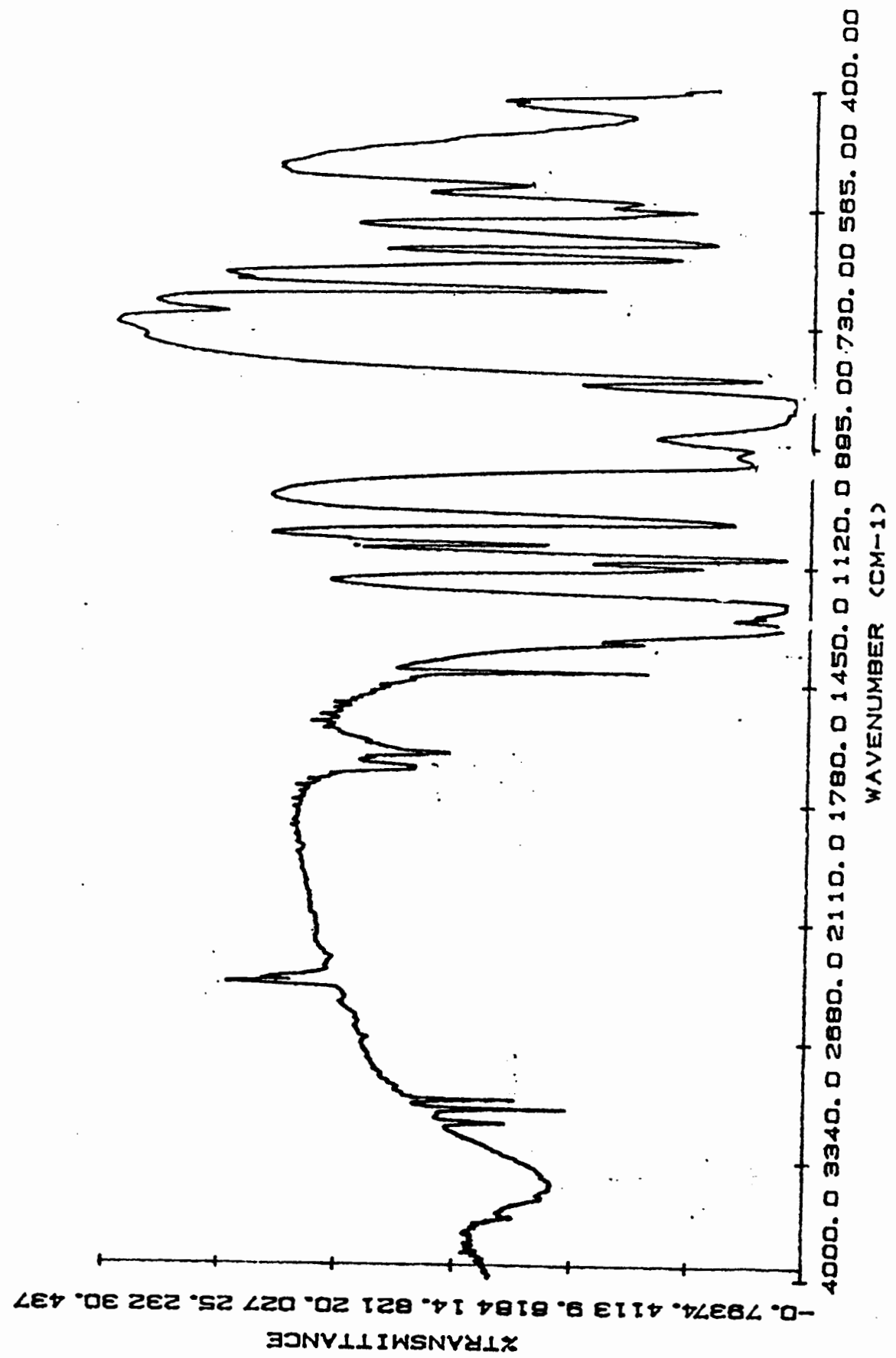

FIGURE 3: Infrared Spectrum of $\mathrm{SF}_{5} \mathrm{CH}_{2} \mathrm{CF}_{2} \mathrm{SO}_{3} \mathrm{Li}$ 


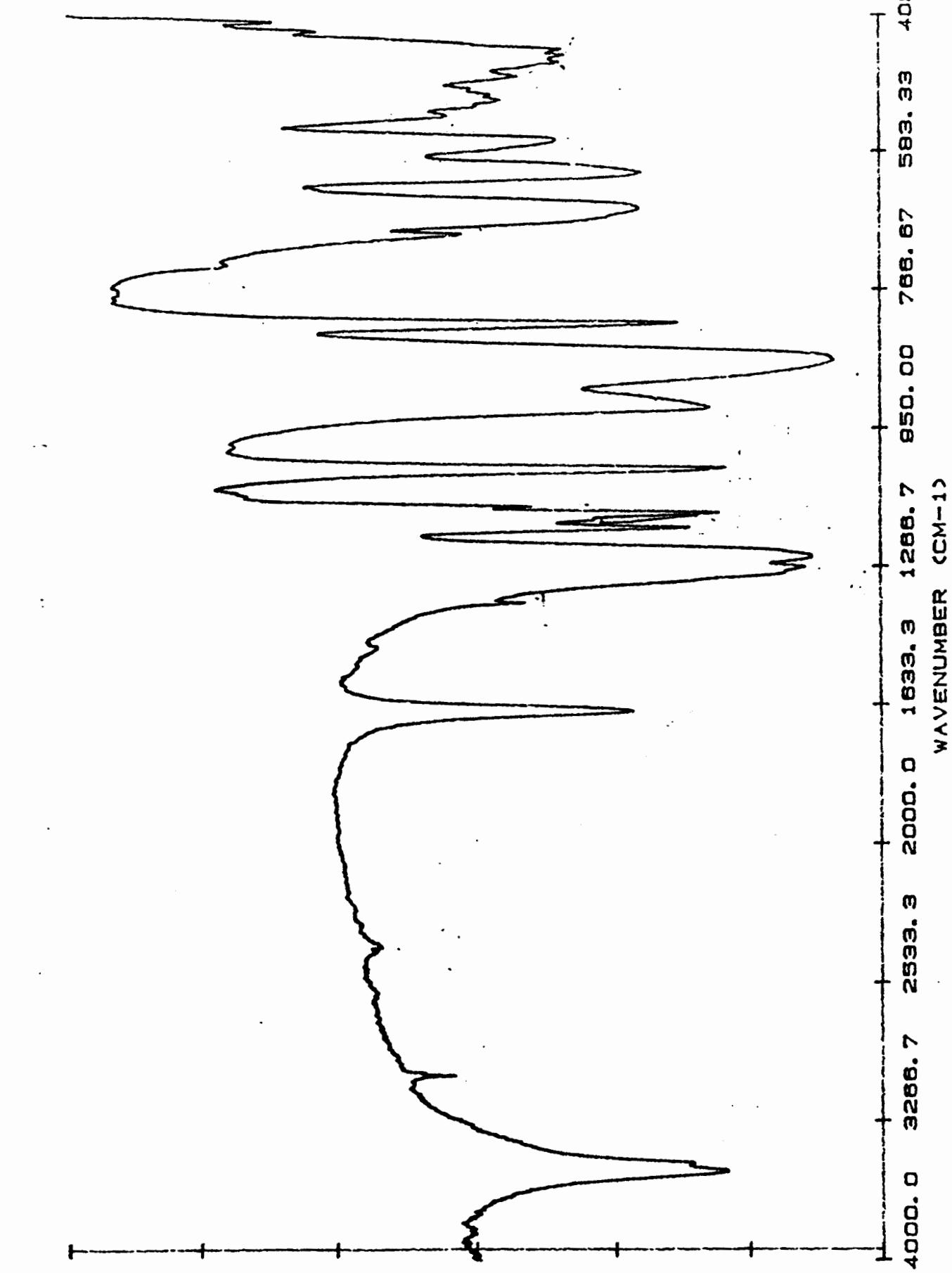

吕

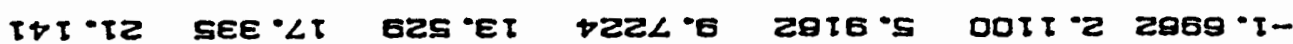

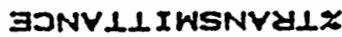

FIGURE 4: Infrared Spectrum of $\mathrm{SF}_{5} \mathrm{CHFCF}_{2} \mathrm{SO}_{3} \mathrm{Li}$ 


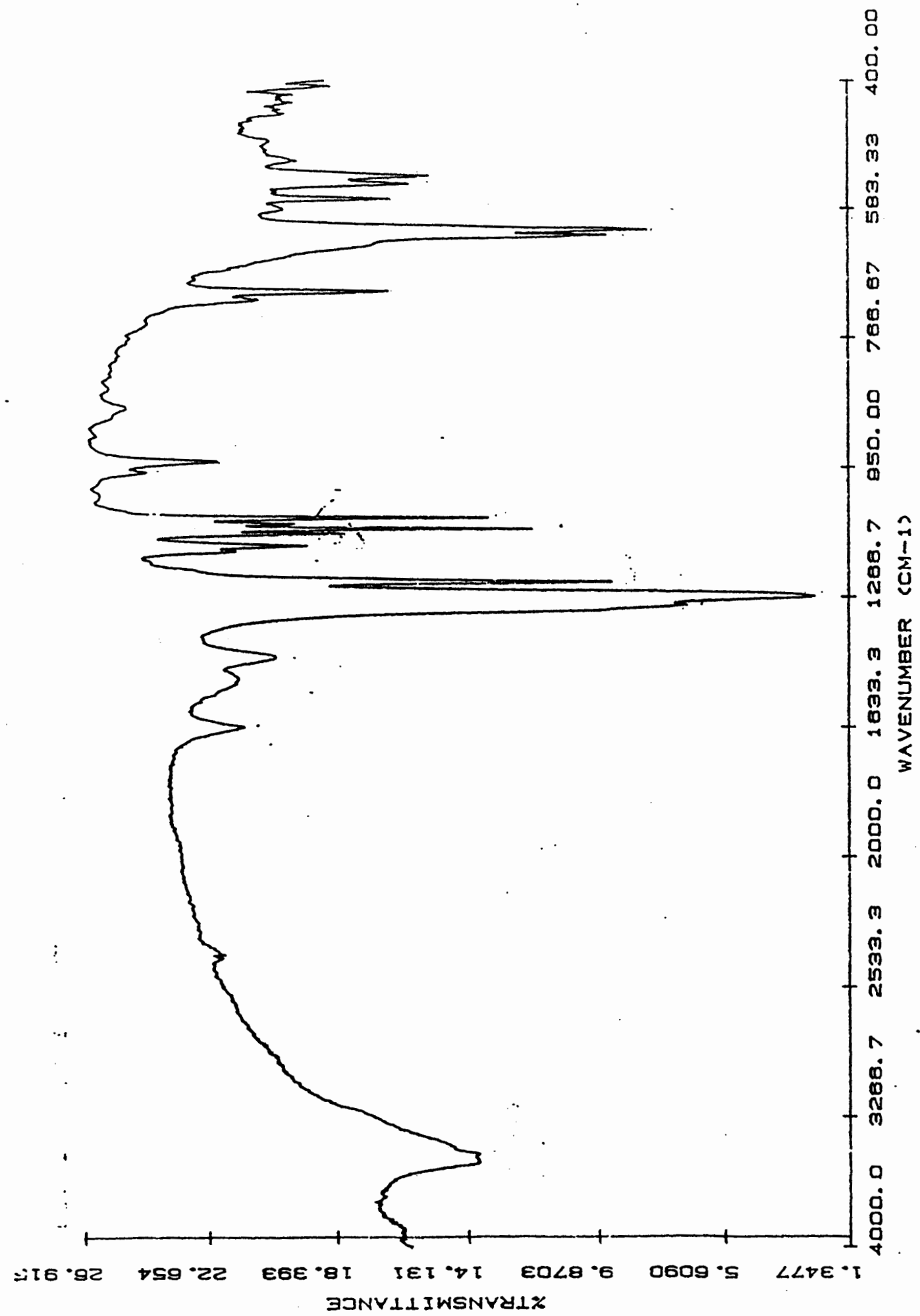

FIGURE 5: Infrared Spectrum of $\mathrm{CF}_{2}\left(\mathrm{SO}_{3} \mathrm{Li}\right)_{2}$ 


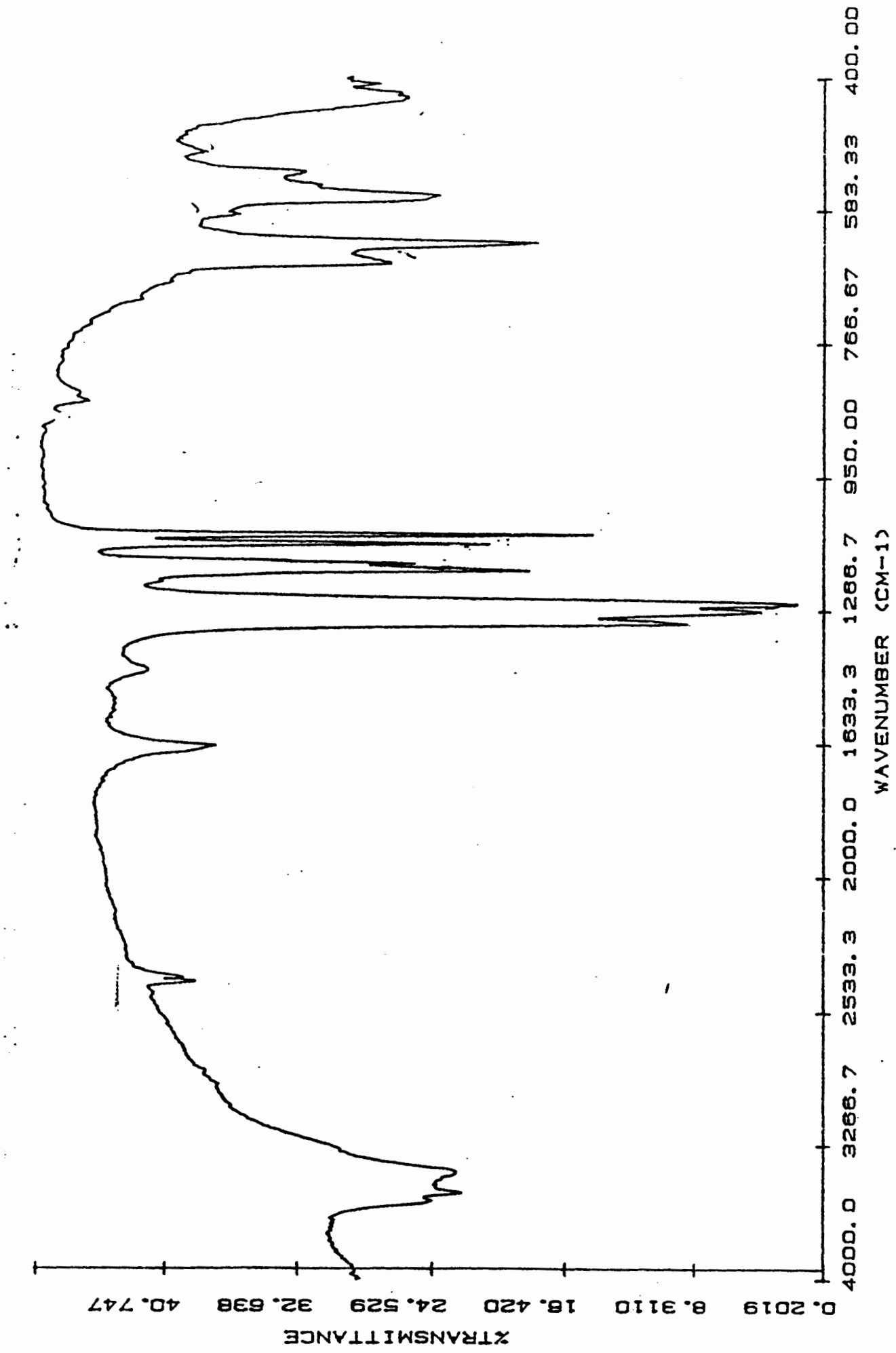

FIGURE 6: Infrared Spectrum of $\left(\mathrm{CF}_{2} \mathrm{SO}_{3} \mathrm{Li}\right)_{2}$ 


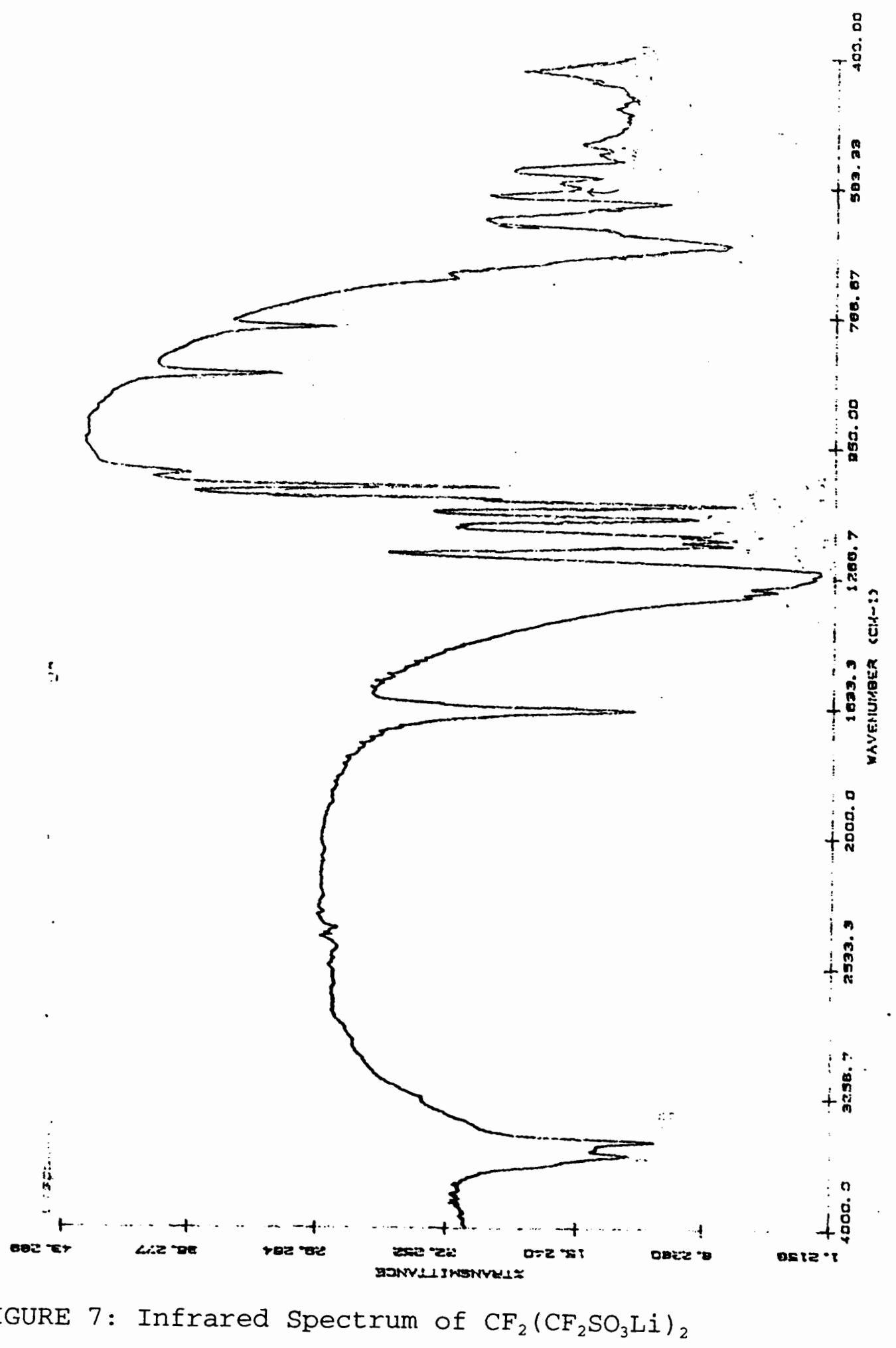




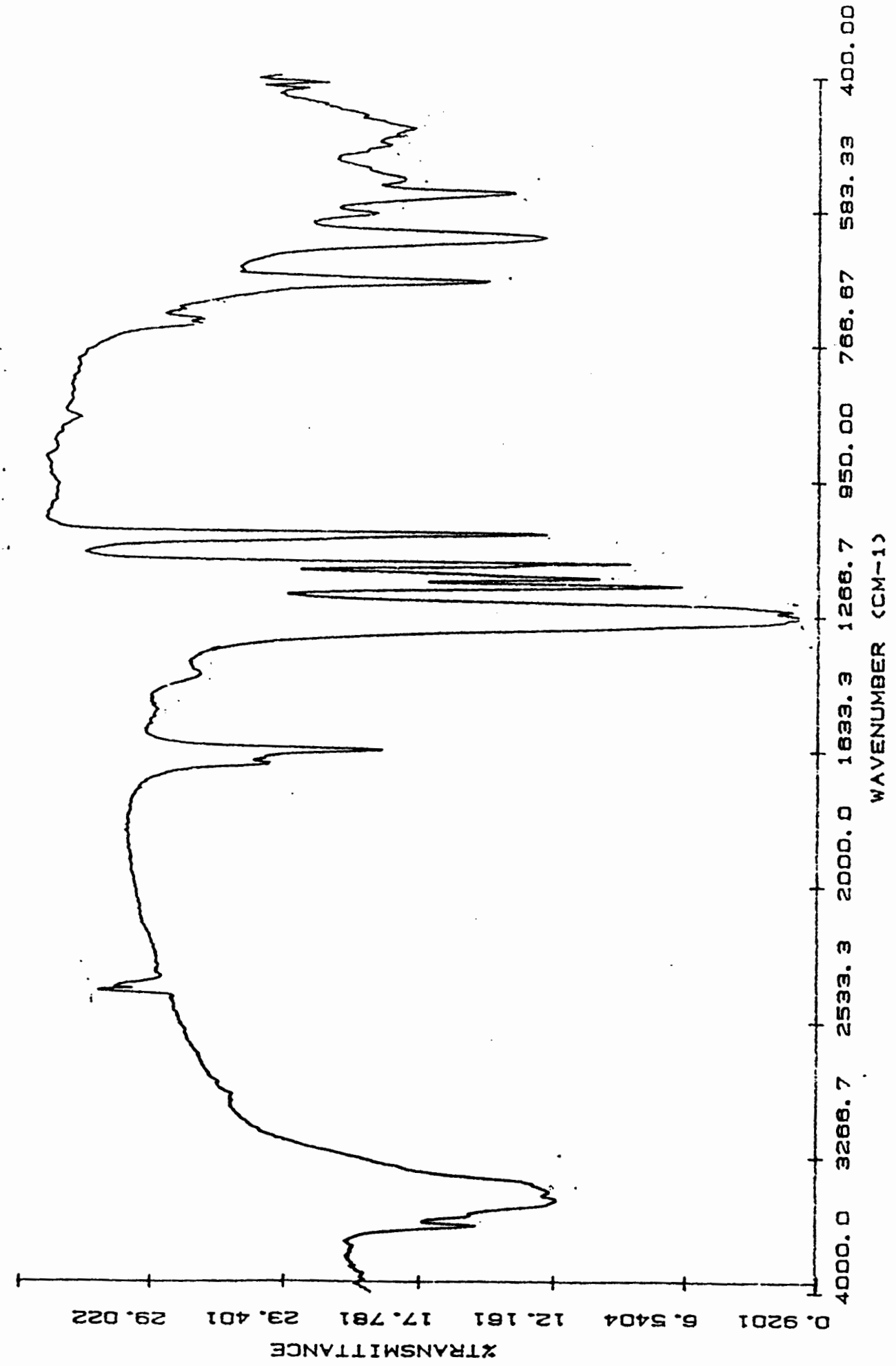

FIGURE 8: Infrared Spectrum of $\left(\mathrm{CF}_{2} \mathrm{CF}_{2} \mathrm{SO}_{3} \mathrm{Li}\right)_{2}$ 


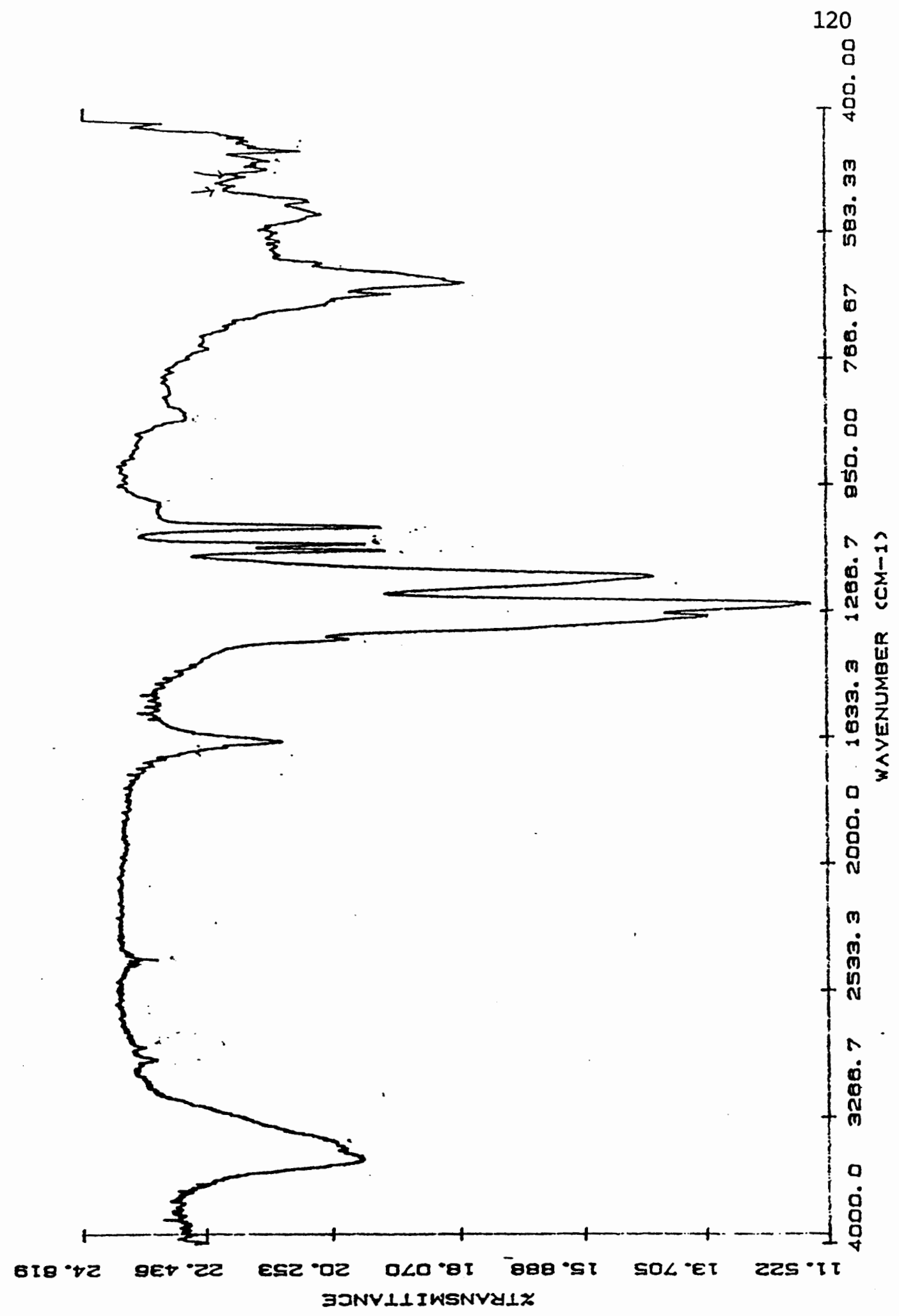

FIGURE 9: Infrared Spectrum of $\mathrm{O}\left(\mathrm{CF}_{2} \mathrm{CF}_{2} \mathrm{SO}_{3} \mathrm{Li}\right)_{2}$ 


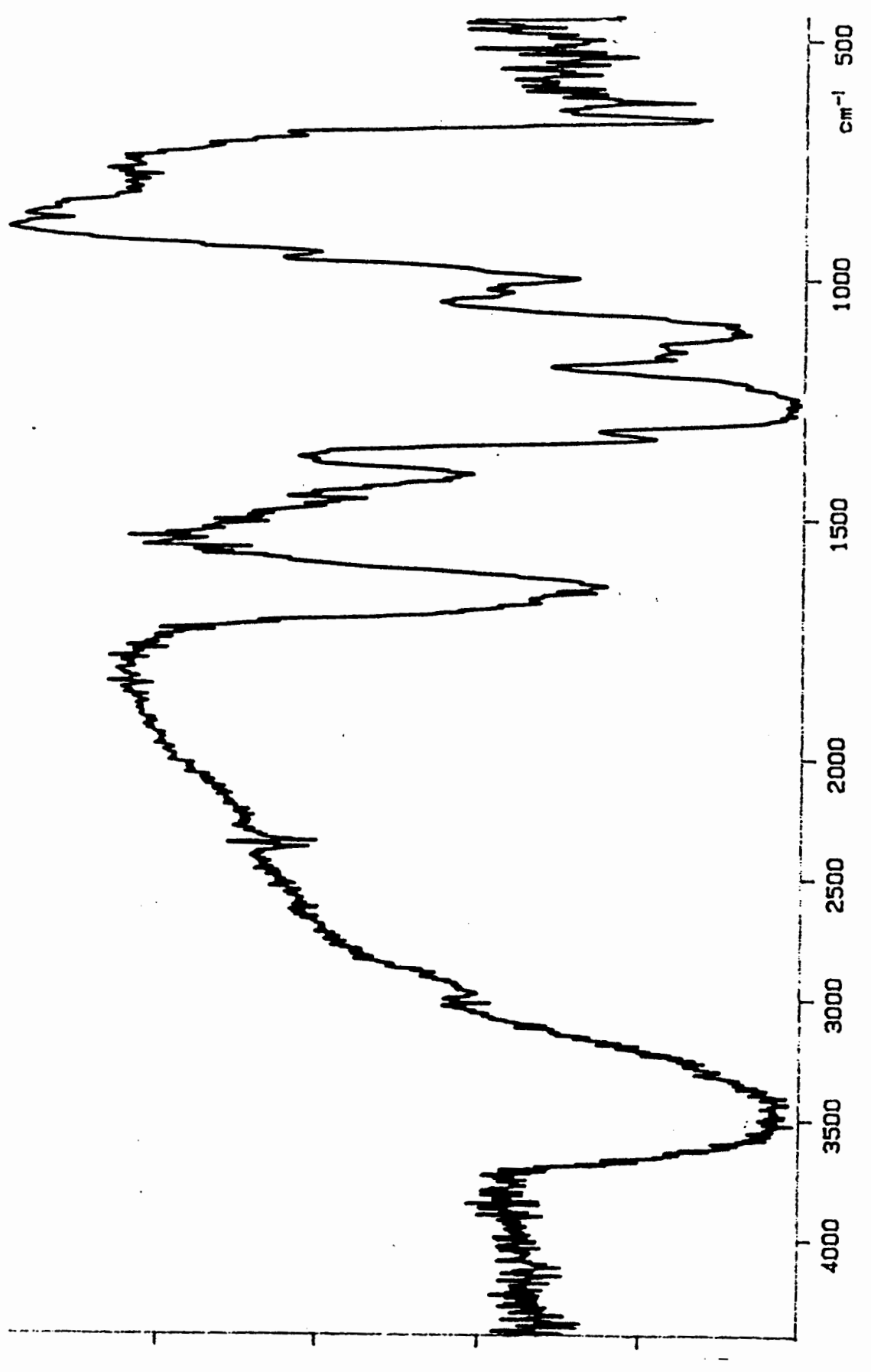

FIGURE 10:

Infrared Spectrum of $\left(\mathrm{OCH}_{2} \mathrm{C}\left(\mathrm{CH}_{2} \mathrm{OCF}_{2} \mathrm{CF}_{2} \mathrm{SO}_{3} \mathrm{Li}\right) \mathrm{H}\right)_{n}$ 

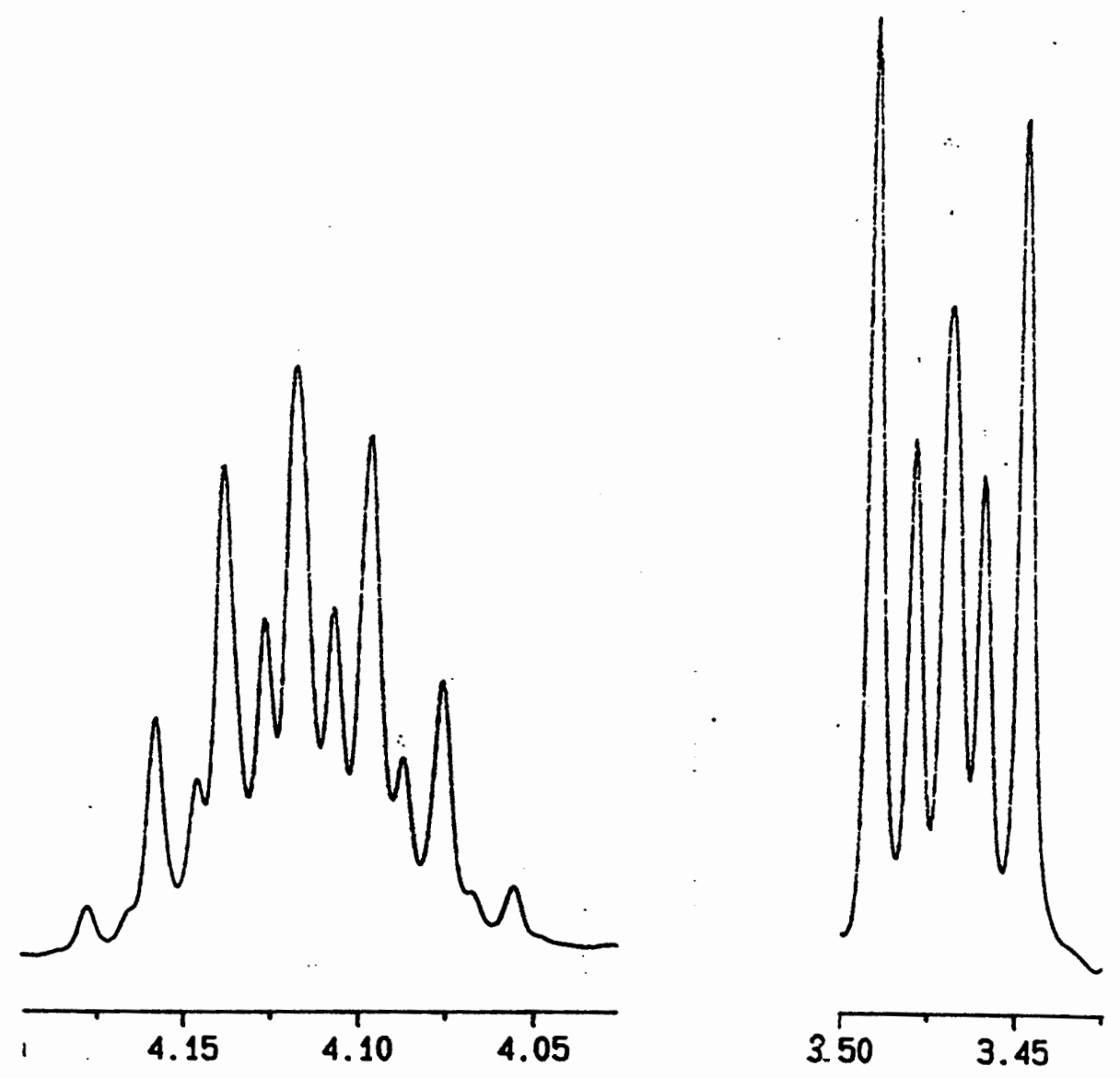

FIGURE 11: $\quad{ }^{1} \mathrm{H}$ NMR Spectrum of $\mathrm{SF}_{5} \mathrm{CH}_{2} \mathrm{CH}_{2} \mathrm{SO}_{3} \mathrm{Li}$ 

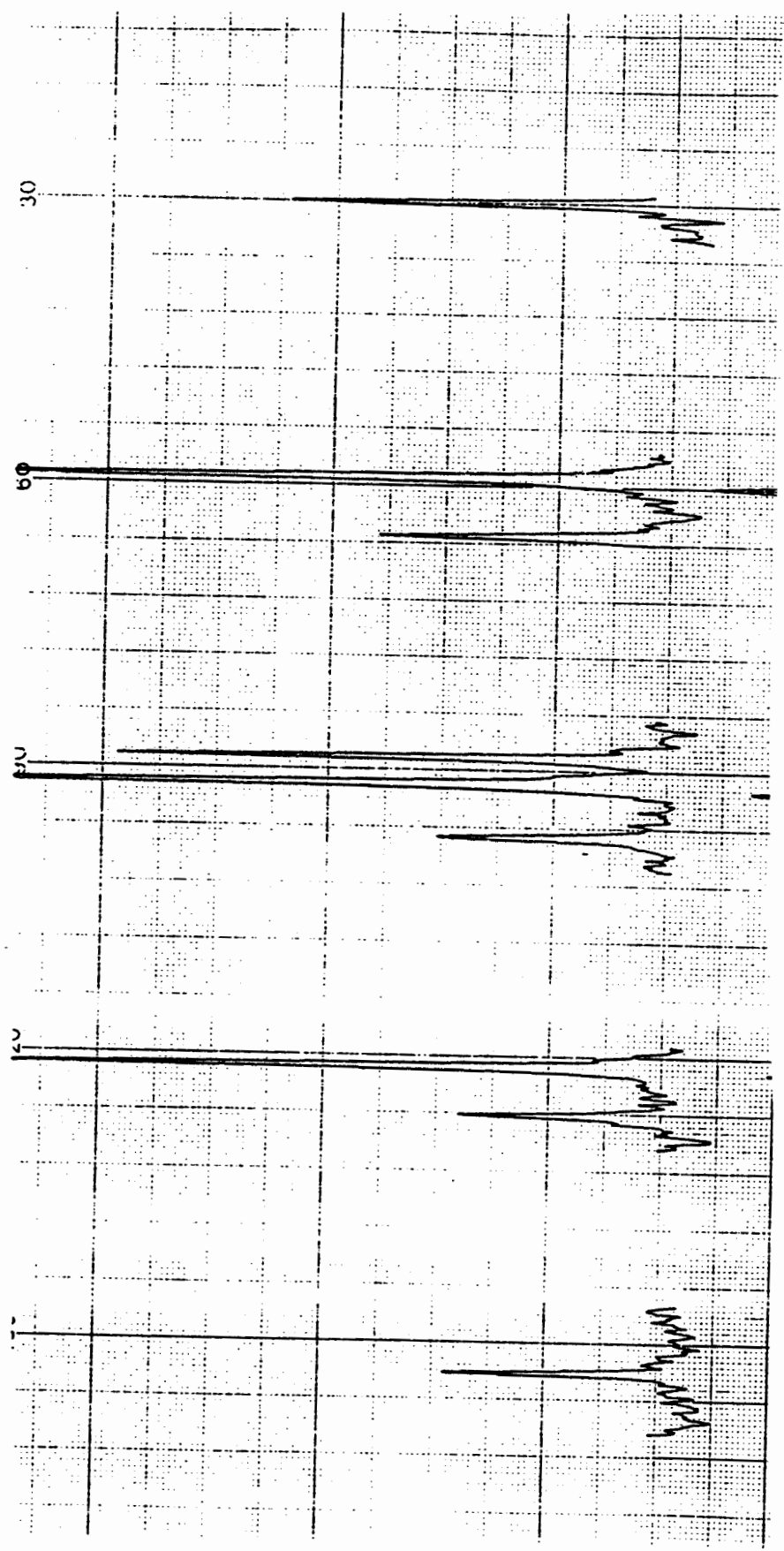

$\begin{array}{ll} & { }^{19} \mathrm{~F} \text { NMR Spectrum of } \mathrm{SF}_{5} \mathrm{CH}_{2} \mathrm{CH}_{2} \mathrm{SO}_{3} \mathrm{Li}-\mathrm{SF}_{5} \text { Axial } \\ \text { Fluorine } & \text { 12: }\end{array}$ 


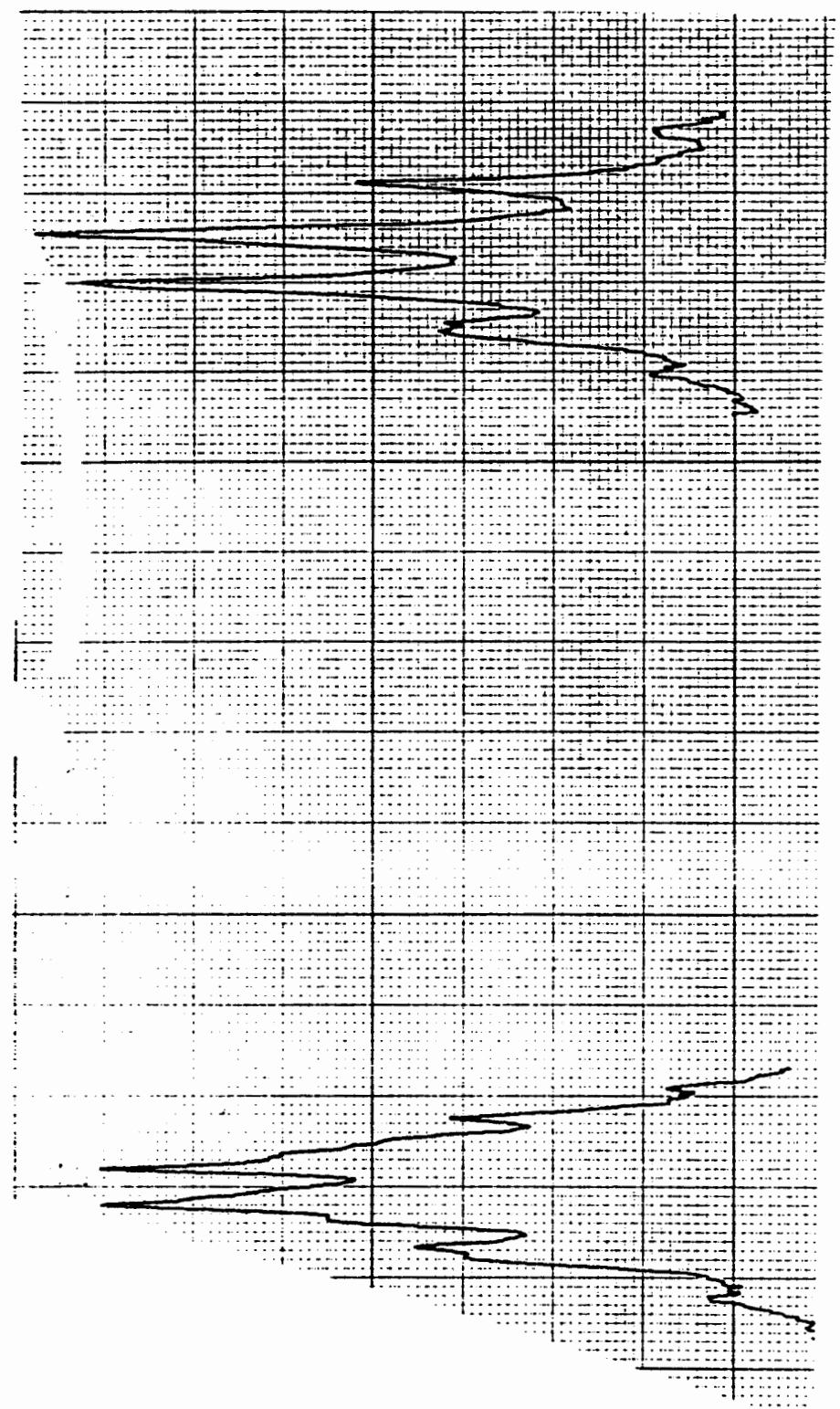

FIGURE 13: $\quad{ }^{19} \mathrm{~F}$ NMR Spectrum of $\mathrm{SF}_{5} \mathrm{CH}_{2} \mathrm{CH}_{2} \mathrm{SO}_{3} \mathrm{Li}-\mathrm{SF}_{5}$ Equatorial Fluorines 


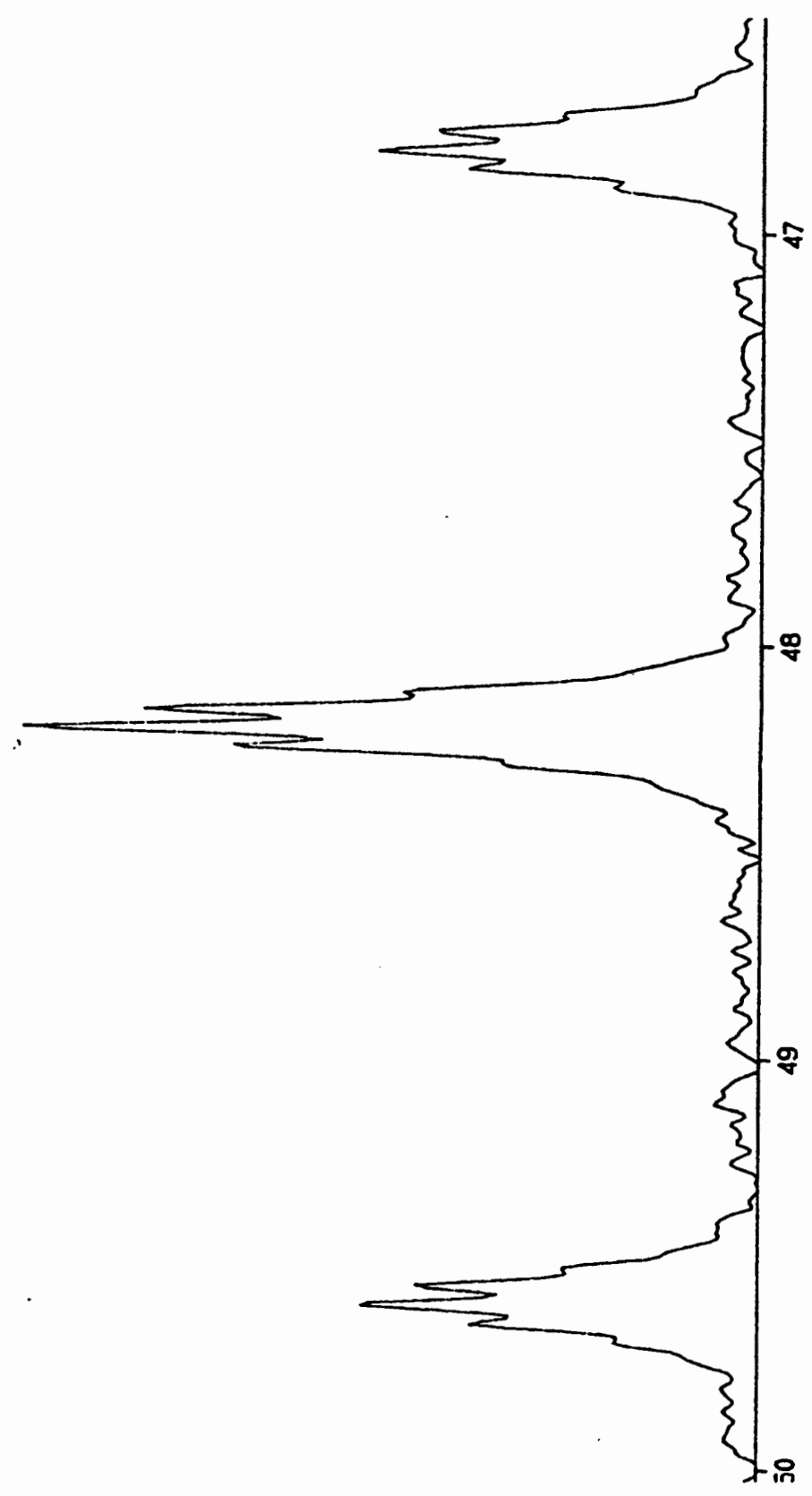

FIGURE 14: ${ }^{19} \mathrm{~F}$ NMR Spectrum of $\mathrm{SF}_{5} \mathrm{CH}_{2} \mathrm{CH}_{2} \mathrm{SO}_{3} \mathrm{Li}-\boldsymbol{\beta}$ Carbon; Proton Coupled 


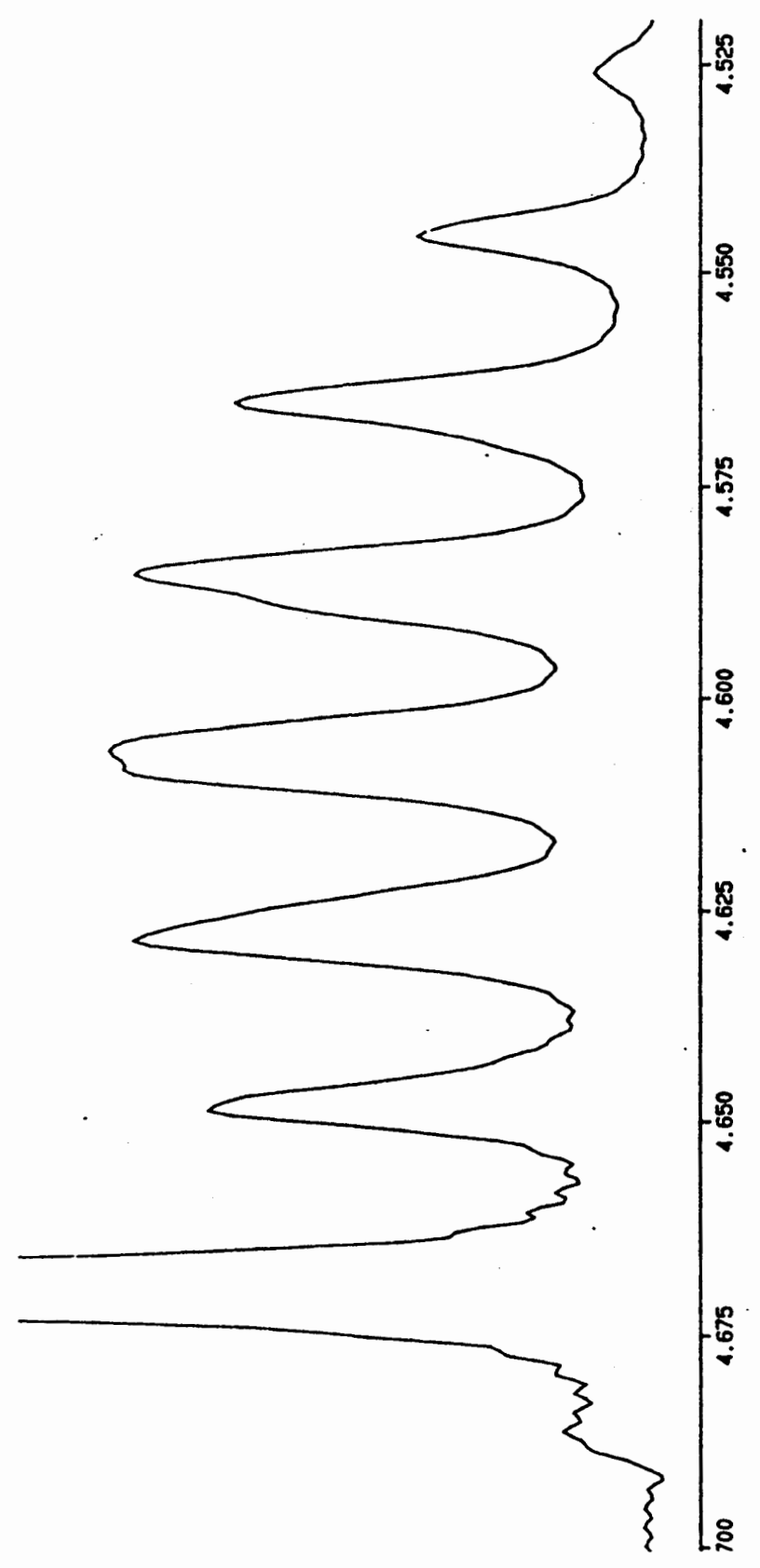

FIGURE 15: $\quad{ }^{1} \mathrm{H}$ NMR Spectrum of $\mathrm{SF}_{5} \mathrm{CH}_{2} \mathrm{CF}_{2} \mathrm{SO}_{3} \mathrm{Li}$ (HDO Peak at about $\delta=4.67$ ) 
$C \underline{F}_{6}$

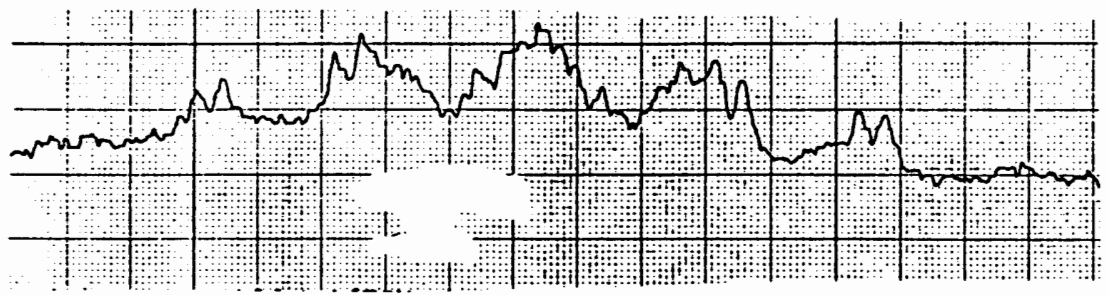

$\mathrm{SF}_{5}$

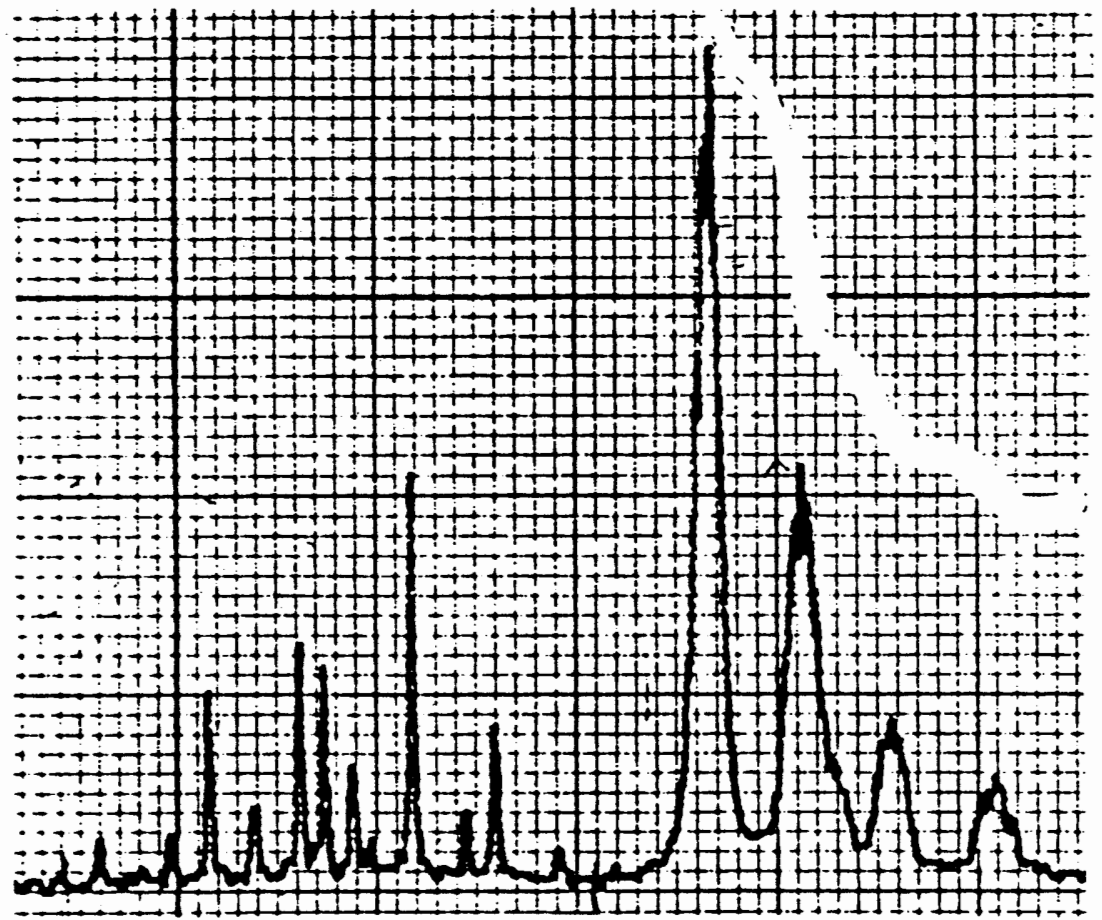

FIGURE 16 :

${ }^{19} \mathrm{~F}$ NMR Spectrum of $\mathrm{SF}_{5} \mathrm{CH}_{2} \mathrm{CF}_{2} \mathrm{SO}_{3} \mathrm{Li}$ 
$\mathrm{C}_{\alpha}$
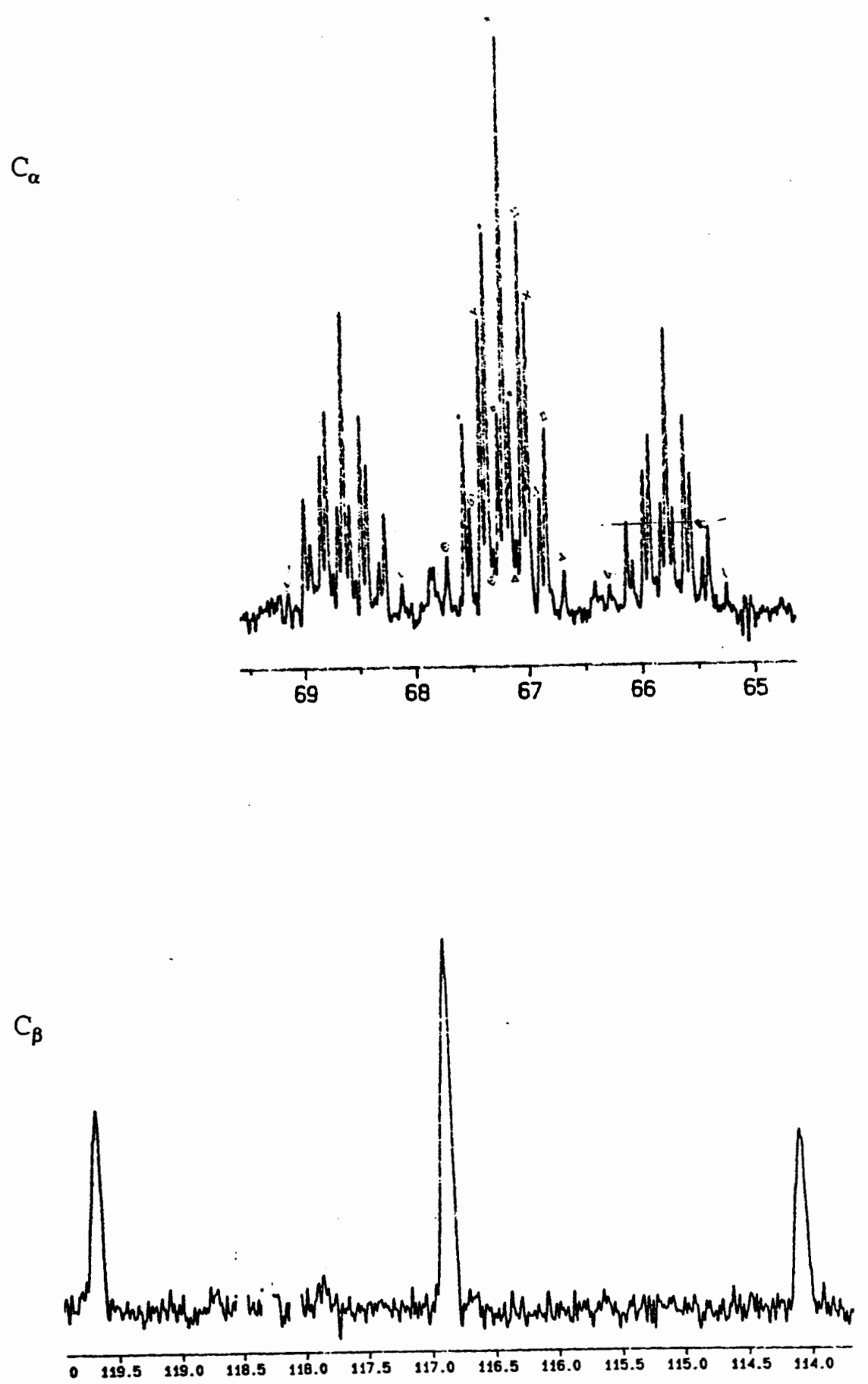

FIGURE 17 :

${ }^{13} \mathrm{C}$ NMR Spectrum of $\mathrm{SF}_{5} \mathrm{CH}_{2} \mathrm{CF}_{2} \mathrm{SO}_{3} \mathrm{Li}$-Proton Coupled 


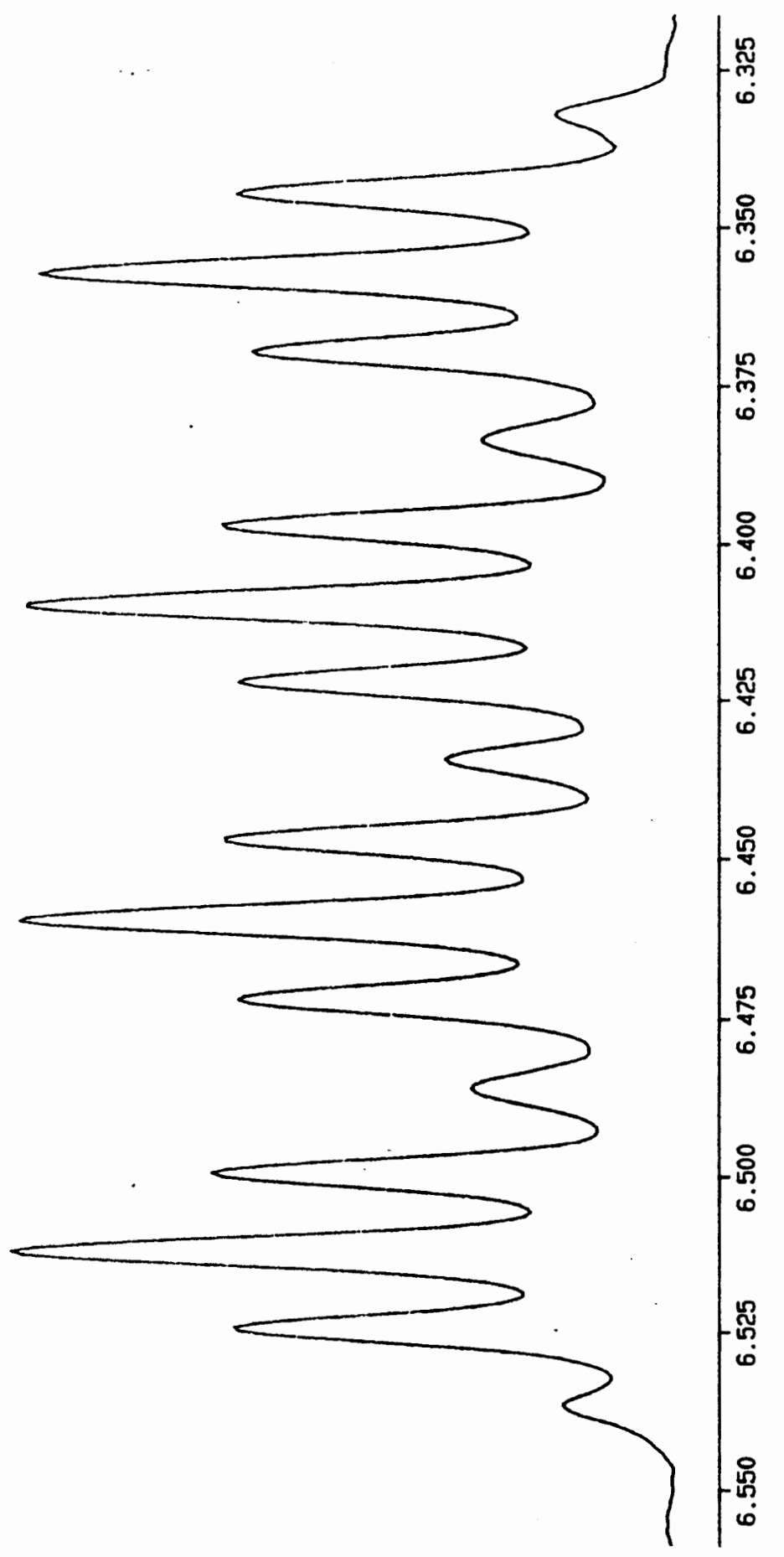

FIGURE 18: $\quad{ }^{1} \mathrm{H}$ NMR Spectrum of $\mathrm{SF}_{5} \mathrm{CHFCF}_{2} \mathrm{SO}_{3} \mathrm{Li}$ 

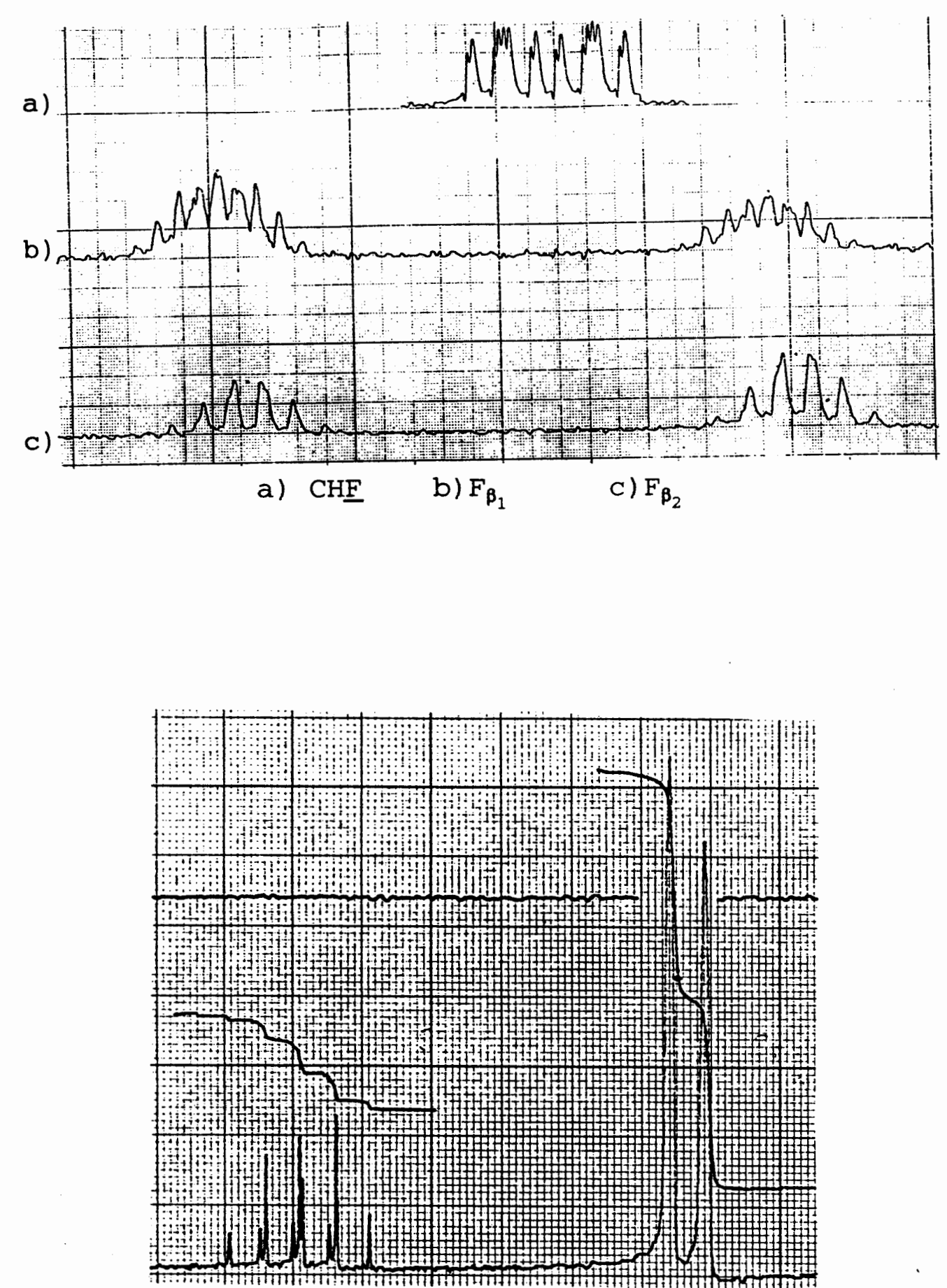

$\mathrm{SF}_{5}$ 


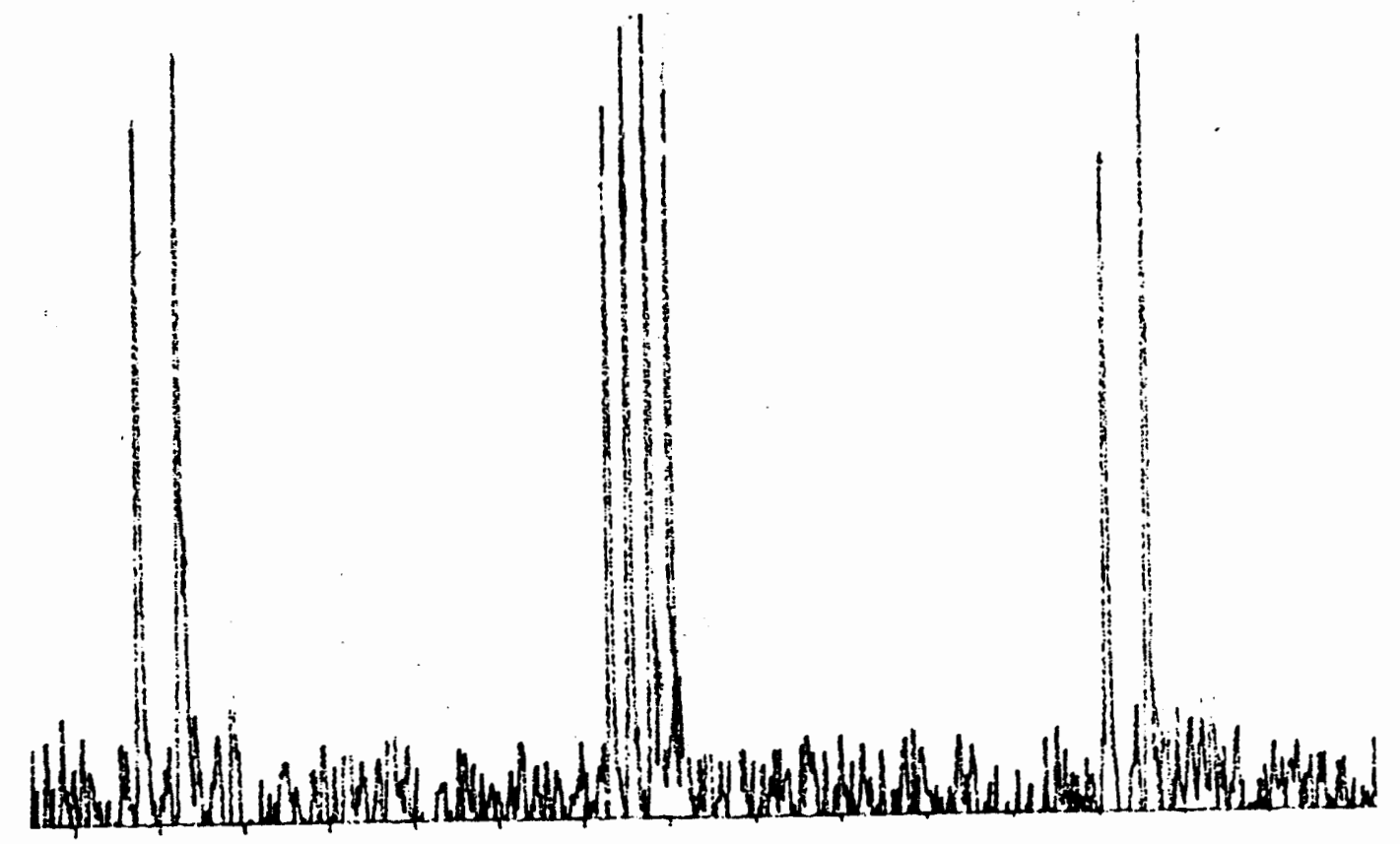

FIGURE 20: ${ }^{13} \mathrm{C}$ NMR Spectrum of $\mathrm{SF}_{5} \mathrm{CHFCF}_{2} \mathrm{SO}_{3} \mathrm{Li}-\boldsymbol{\beta}$ Carbon, Proton Decoupled 

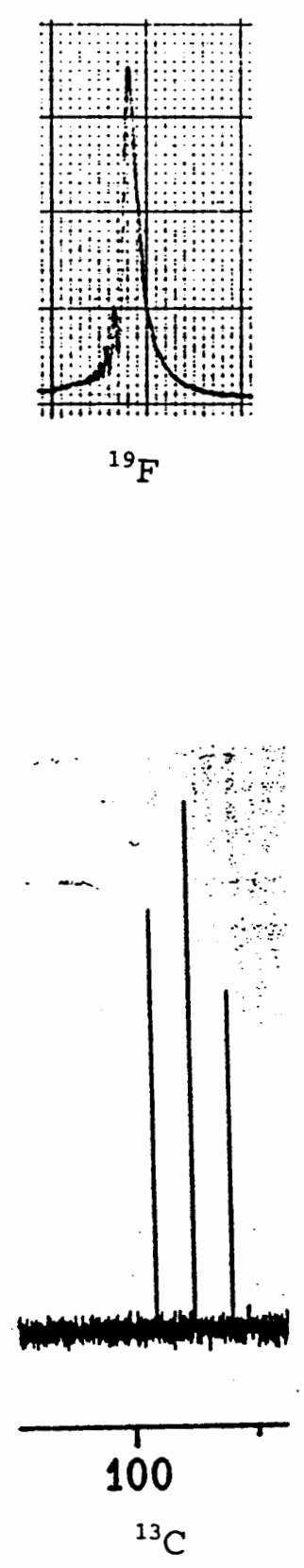

FIGURE 21: ${ }^{19} \mathrm{~F}$ and ${ }^{13} \mathrm{C}$ NMR spectra of $\mathrm{CF}_{2}\left(\mathrm{SO}_{3} \mathrm{Li}\right)_{2}$ 


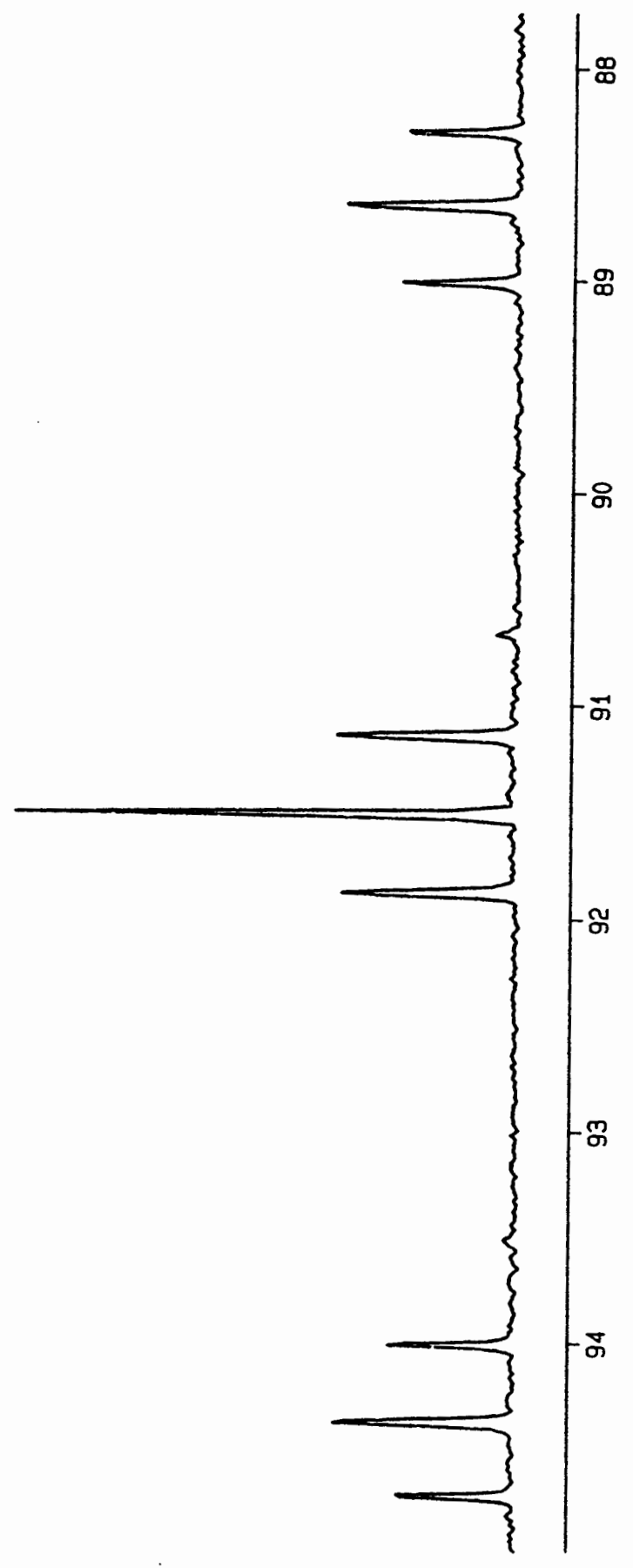

FIGURE 22: ${ }^{13} \mathrm{C}$ NMR Spectrum of $\left(\mathrm{CF}_{2} \mathrm{SO}_{3} \mathrm{Li}\right)_{2}$ 

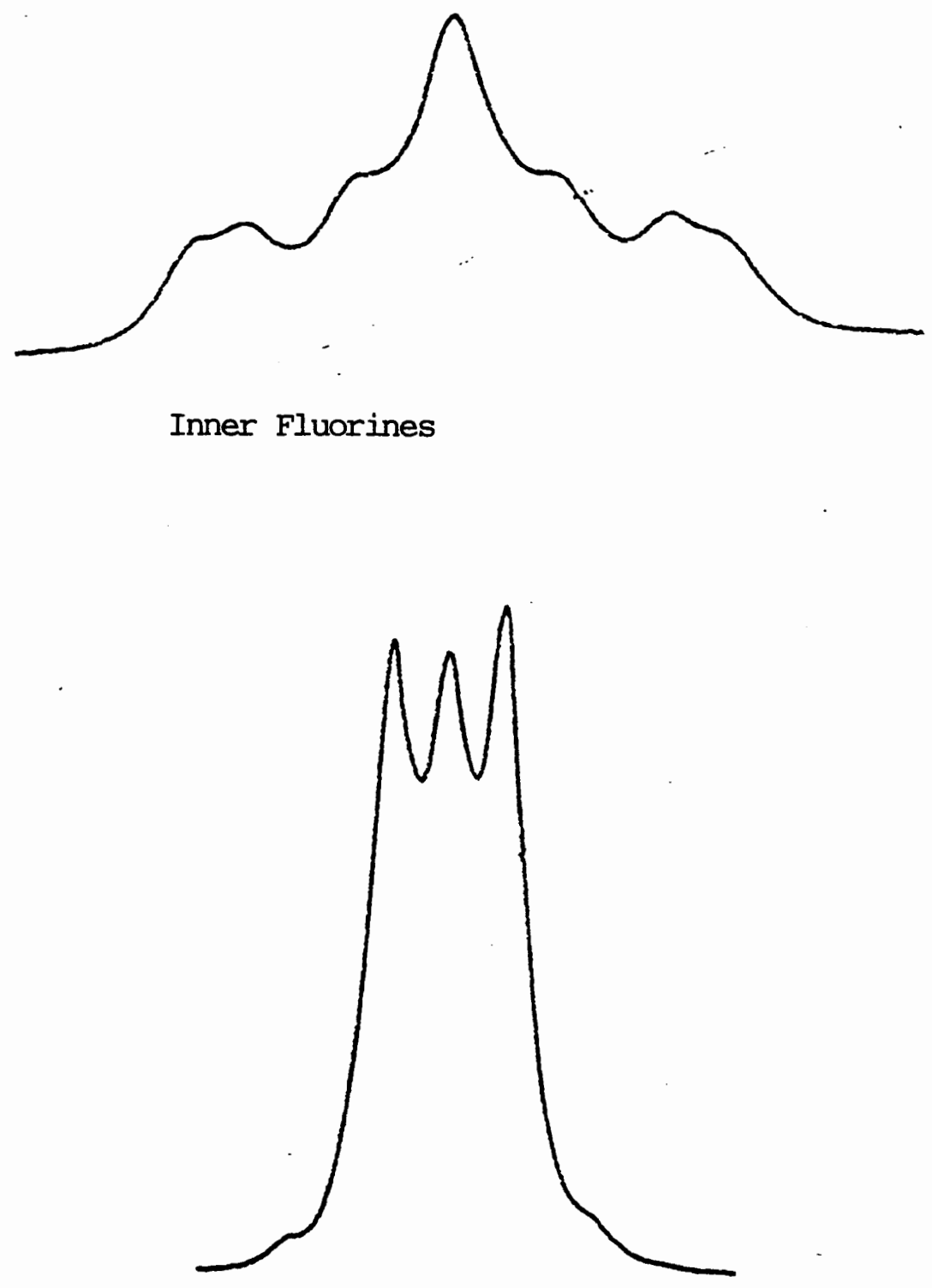

Outer Fluorines

FIGURE 23: ${ }^{19} \mathrm{~F}$ NMR Spectra of $\mathrm{CF}_{2}\left(\mathrm{CF}_{2} \mathrm{SO}_{3} \mathrm{Li}\right)_{2}$ 


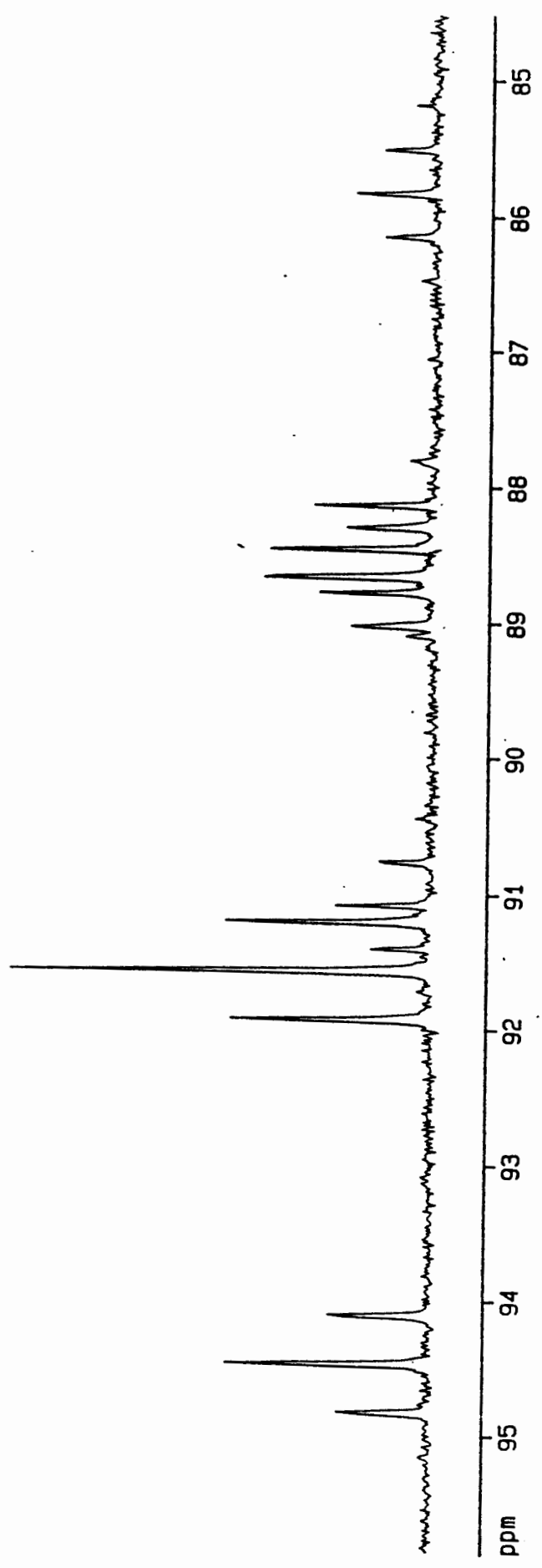

FIGURE 24: ${ }^{13} \mathrm{C}$ NMR spectrum of $\mathrm{CF}_{2}\left(\mathrm{CF}_{2} \mathrm{SO}_{3} \mathrm{Li}\right)_{2}$ 

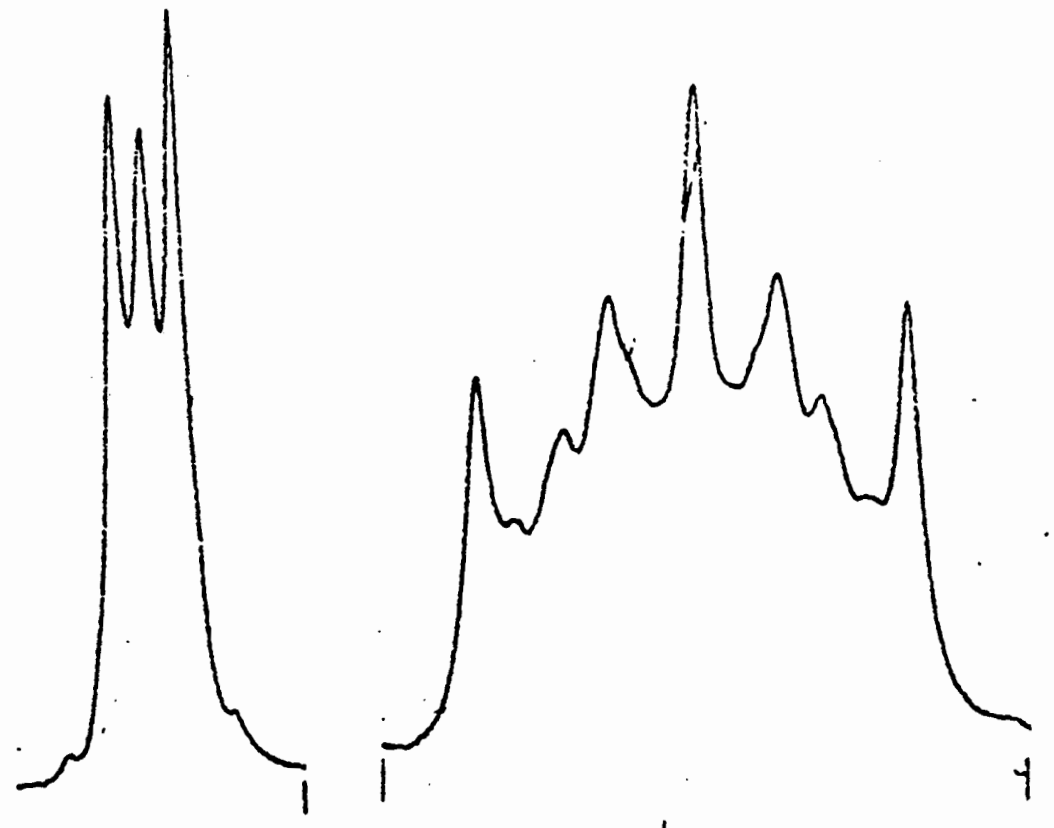

Inner Fluorines
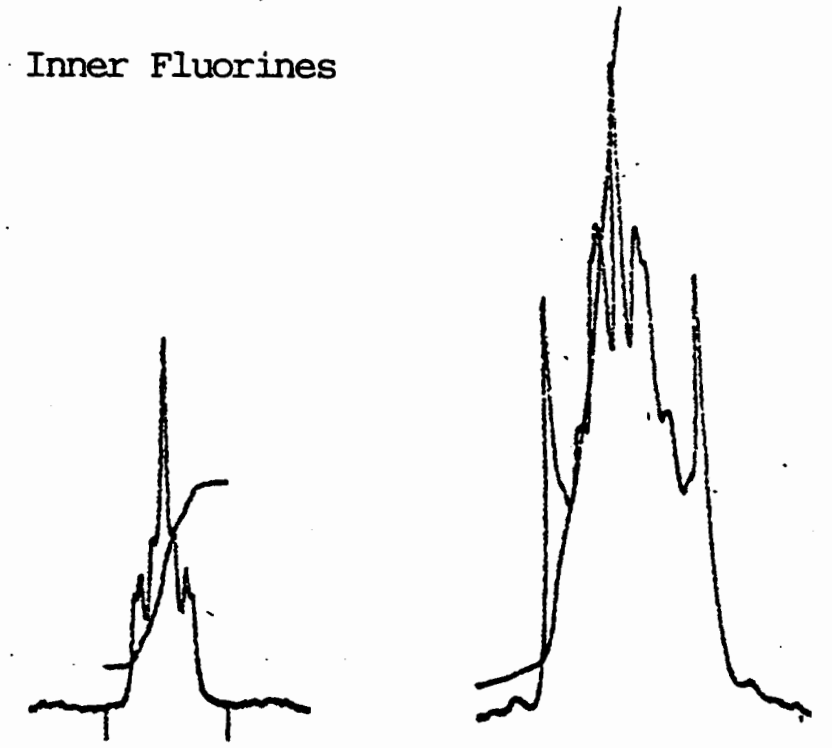

Outer Fluorines

FIGURE 25:

${ }^{19} \mathrm{~F}$ NMR Spectra of $\left(\mathrm{CF}_{2} \mathrm{CF}_{2} \mathrm{SO}_{3} \mathrm{Li}\right)_{2}$

Possibly contaminated with $\mathrm{CF}_{2}\left(\mathrm{CF}_{2} \mathrm{SO}_{3} \mathrm{Li}\right)_{2}$ 


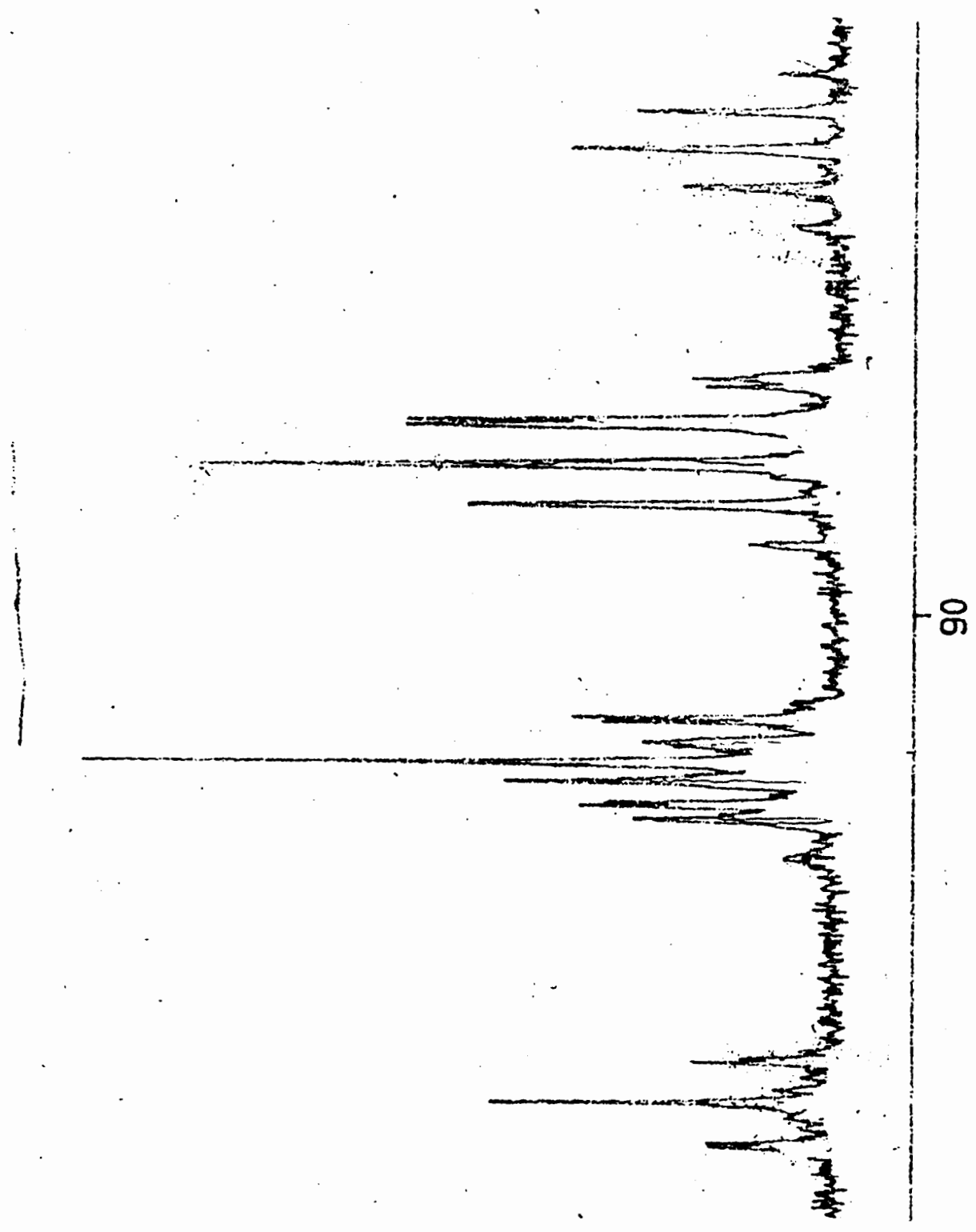

FIGURE 26: $\quad{ }^{13} \mathrm{C}$ NMR spectra of $\left(\mathrm{CF}_{2} \mathrm{CF}_{2} \mathrm{SO}_{3} \mathrm{Li}\right)_{2}$ 

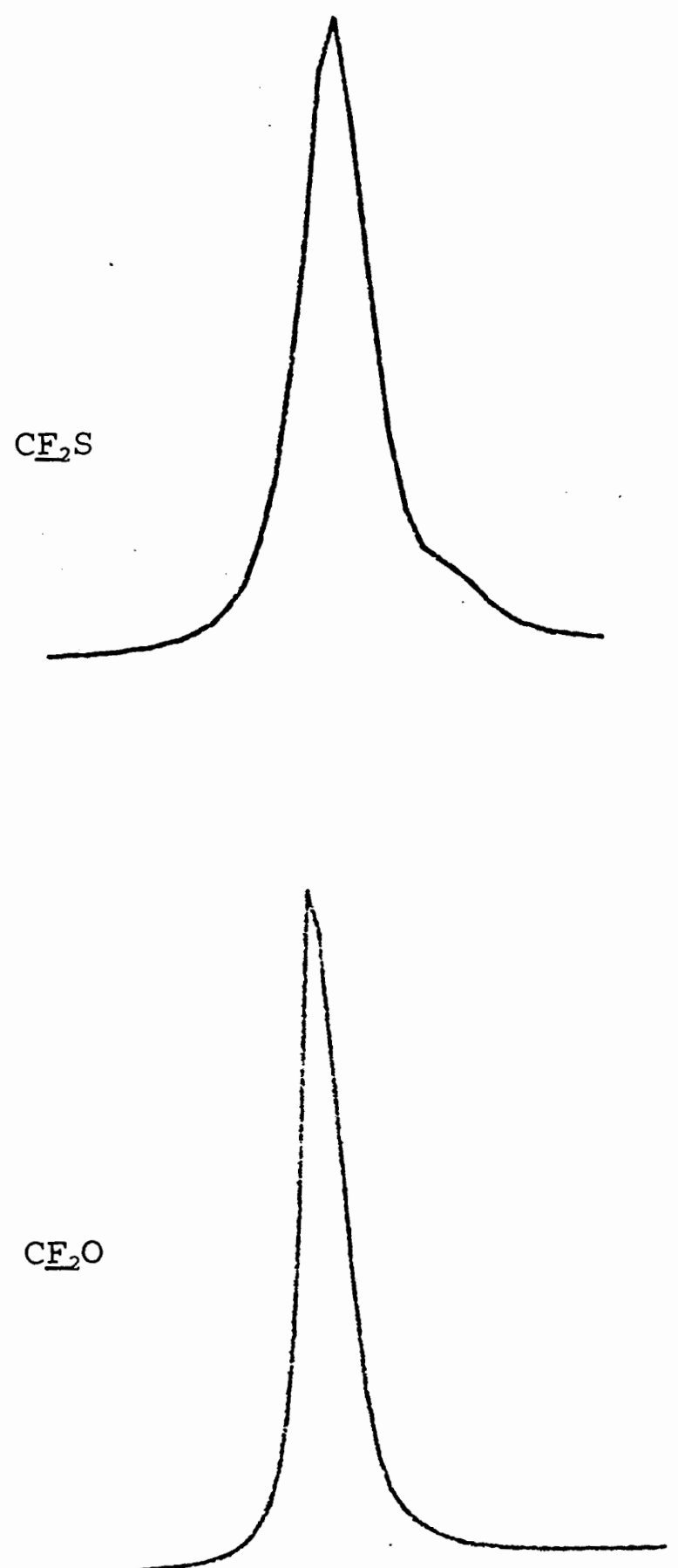

FIGURE 27 :

${ }^{19} \mathrm{~F}$ NMR Spectra of $\mathrm{O}\left(\mathrm{CF}_{2} \mathrm{CF}_{2} \mathrm{SO}_{3} \mathrm{Li}\right)_{2}$ 

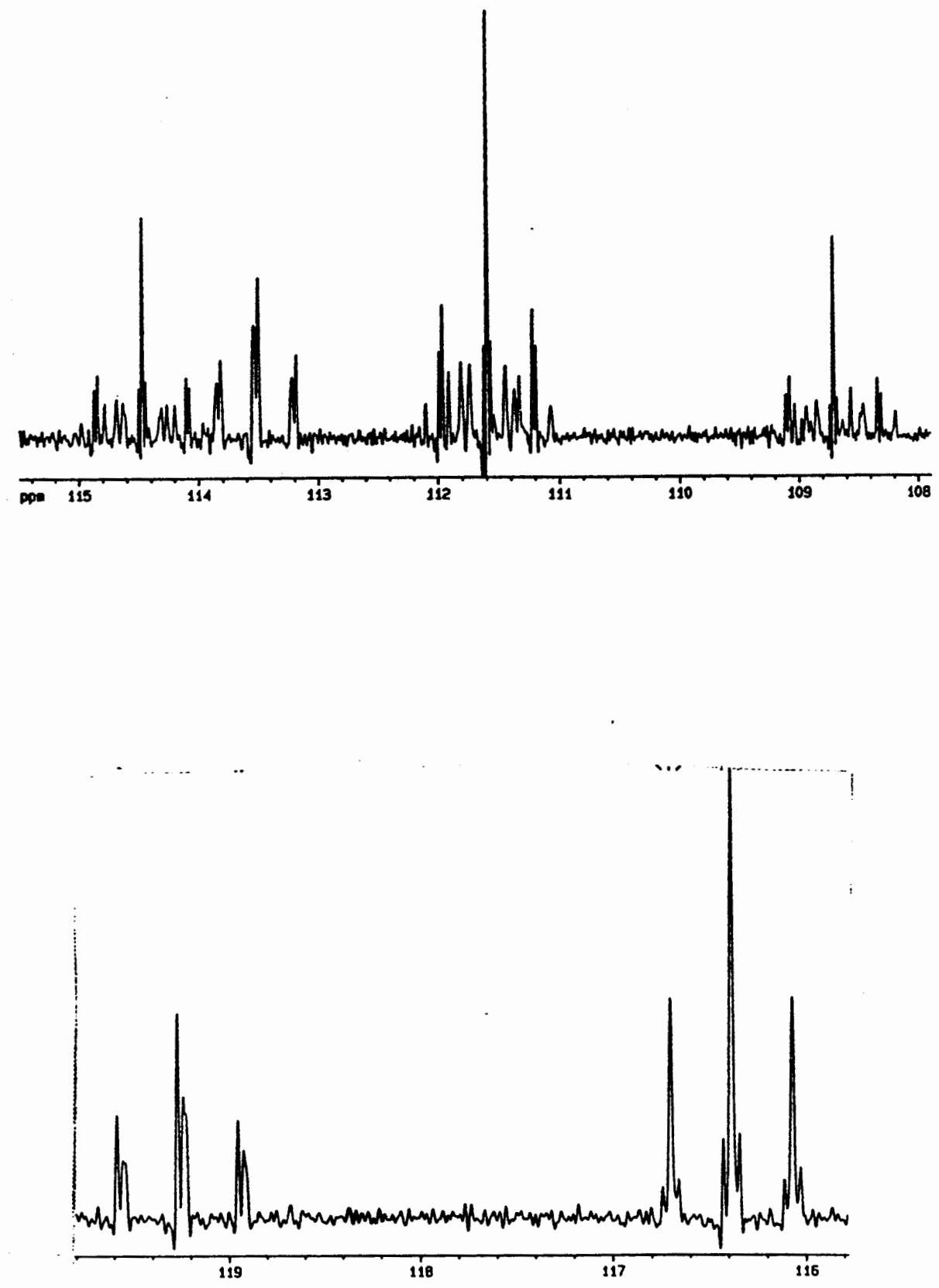

FIGURE 28: ${ }^{13} \mathrm{C}$ NMR Spectra of $\mathrm{O}\left(\mathrm{CF}_{2} \mathrm{CF}_{2} \mathrm{SO}_{3} \mathrm{Li}\right)_{2}$ 


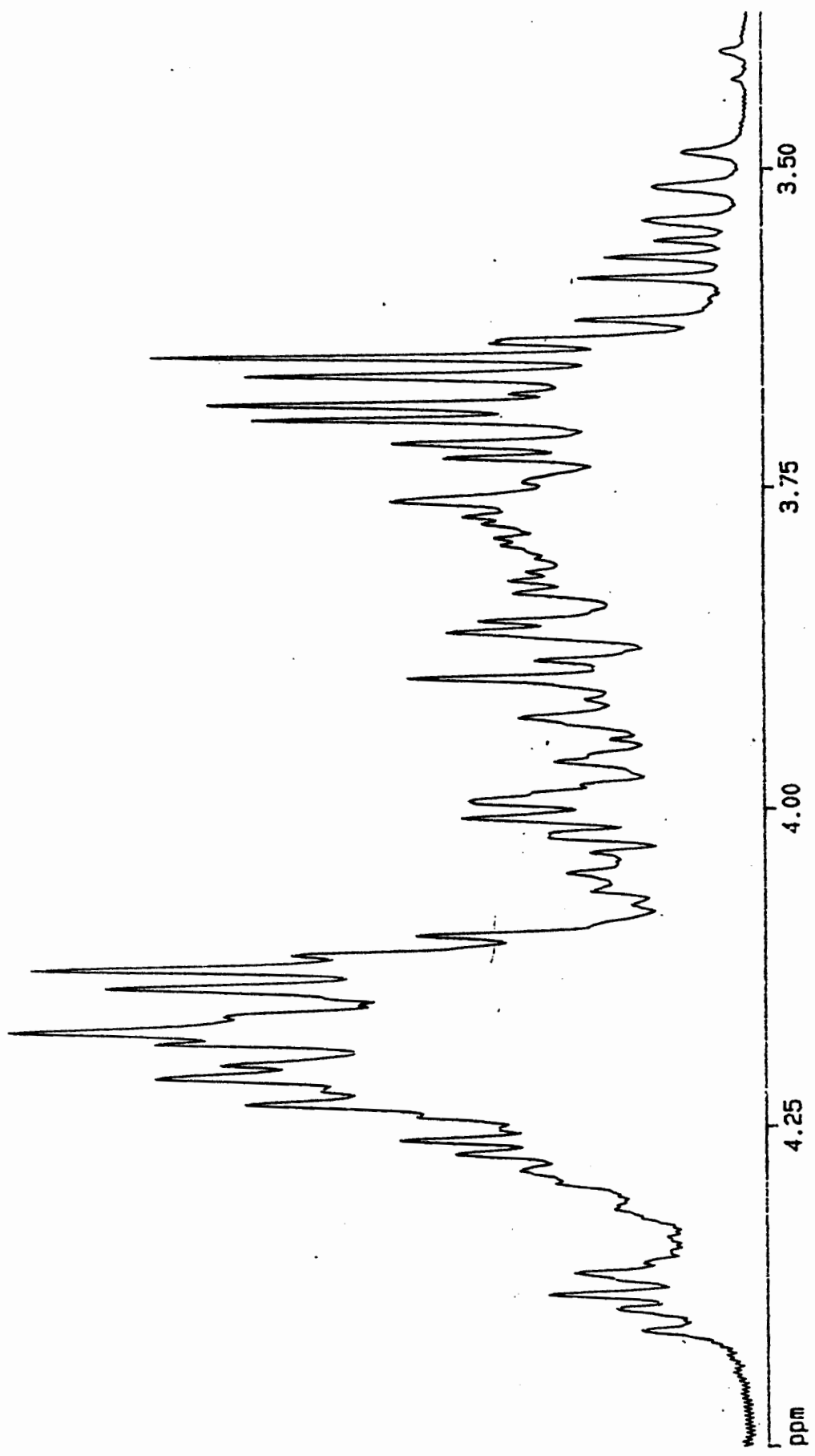

FIGURE 29:

${ }^{1} \mathrm{H}$ NMR Spectrum of $\left(\mathrm{OCH}_{2} \mathrm{C}\left(\mathrm{CH}_{2} \mathrm{OCF}_{2} \mathrm{CF}_{2} \mathrm{SO}_{3} \mathrm{Li}\right) \mathrm{H}\right)_{\mathrm{n}}$ 

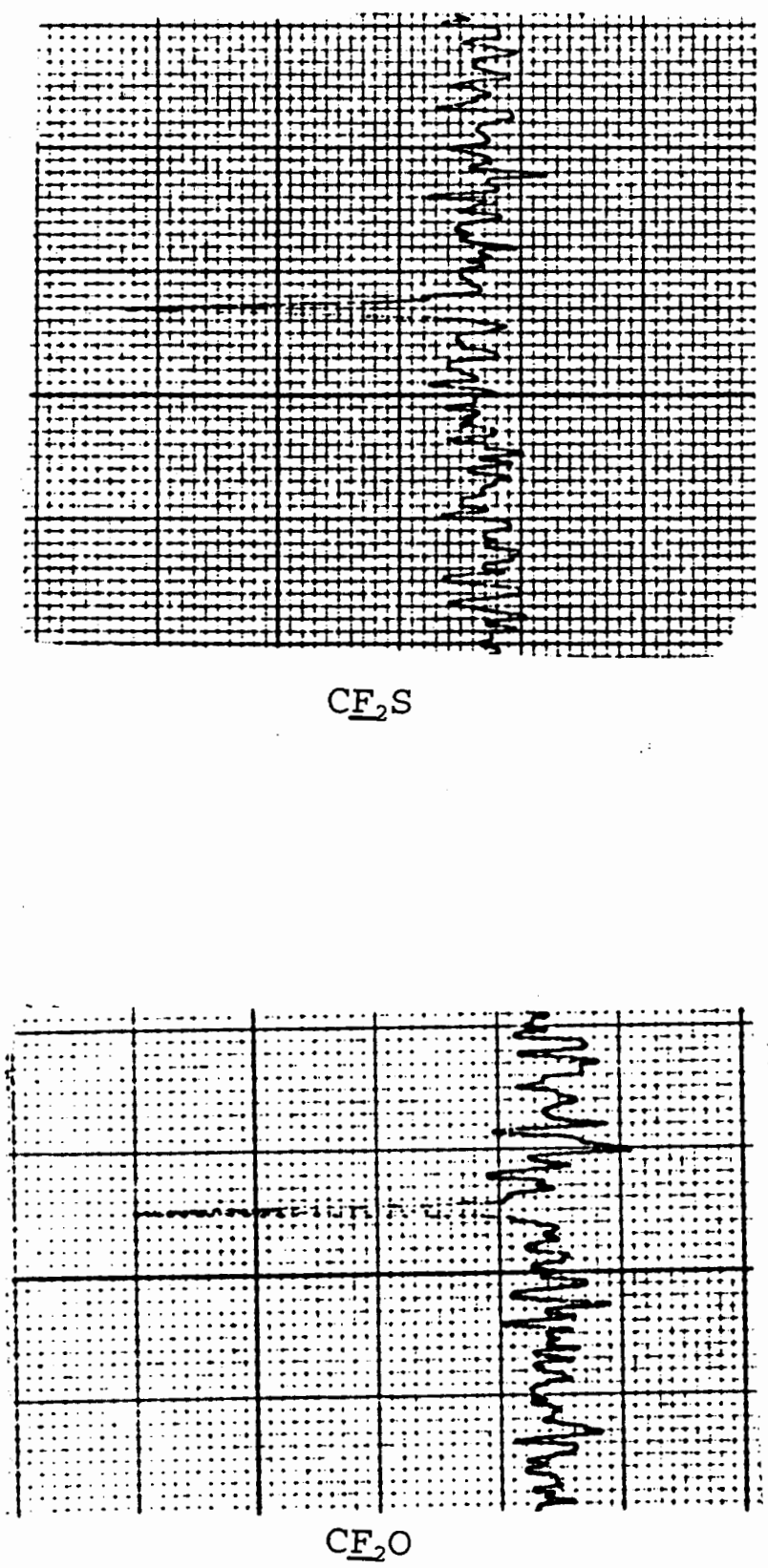

FIGURE 30:

${ }^{19} \mathrm{~F}$ NMR Spectrum of $\left(\mathrm{OCH}_{2} \mathrm{C}\left(\mathrm{CH}_{2} \mathrm{OCF}_{2} \mathrm{CF}_{2} \mathrm{SO}_{3} \mathrm{Li}\right) \mathrm{H}\right)_{\mathrm{n}}$ 